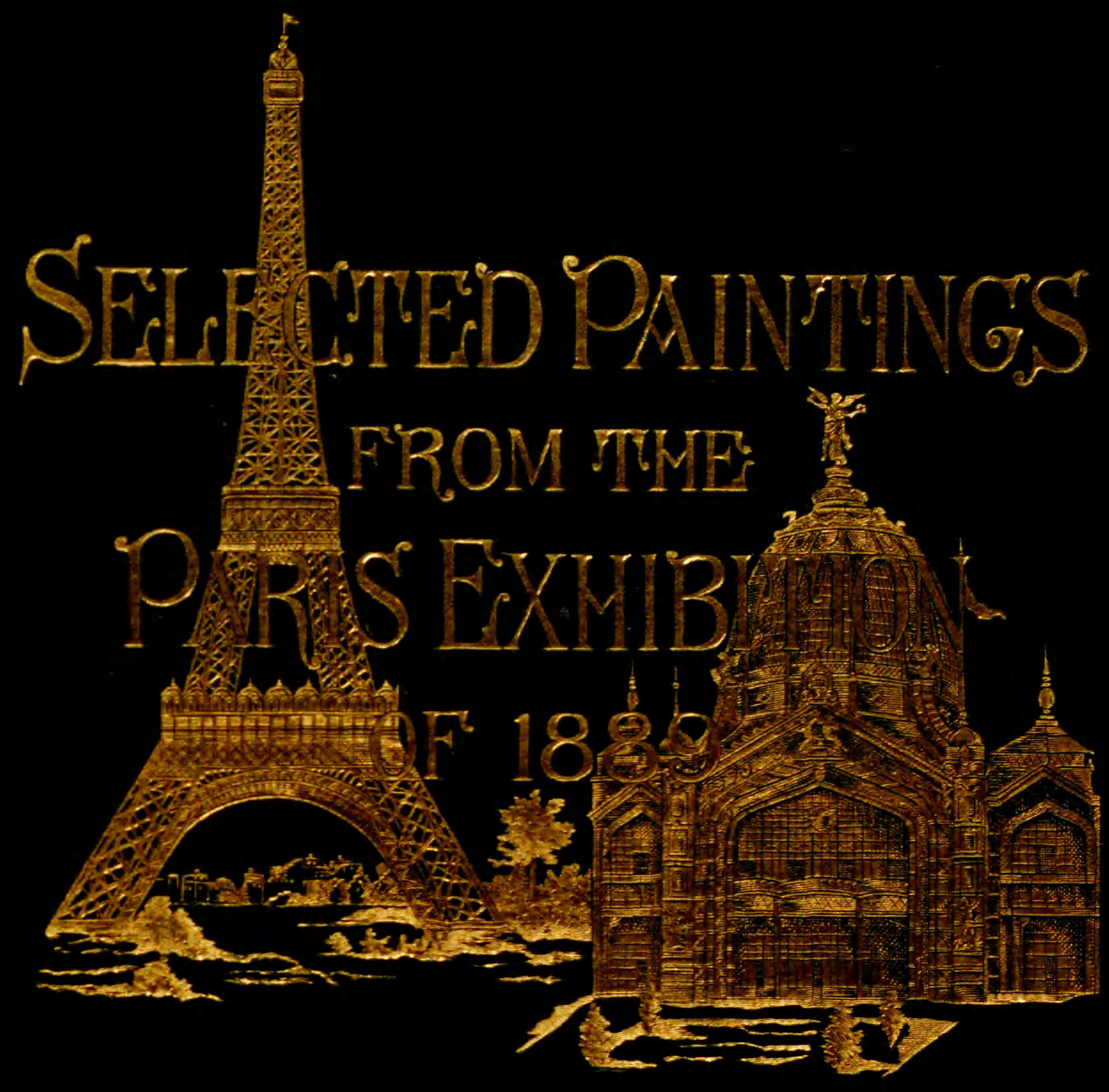





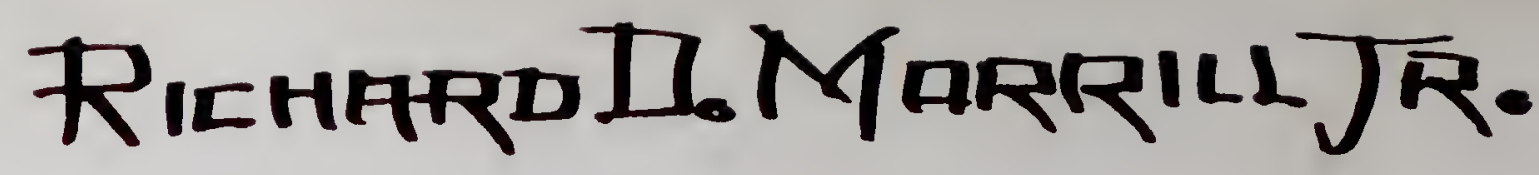


962 


\section{Selected Paintings}

FRON THE:

PARIS EXHIBITION 




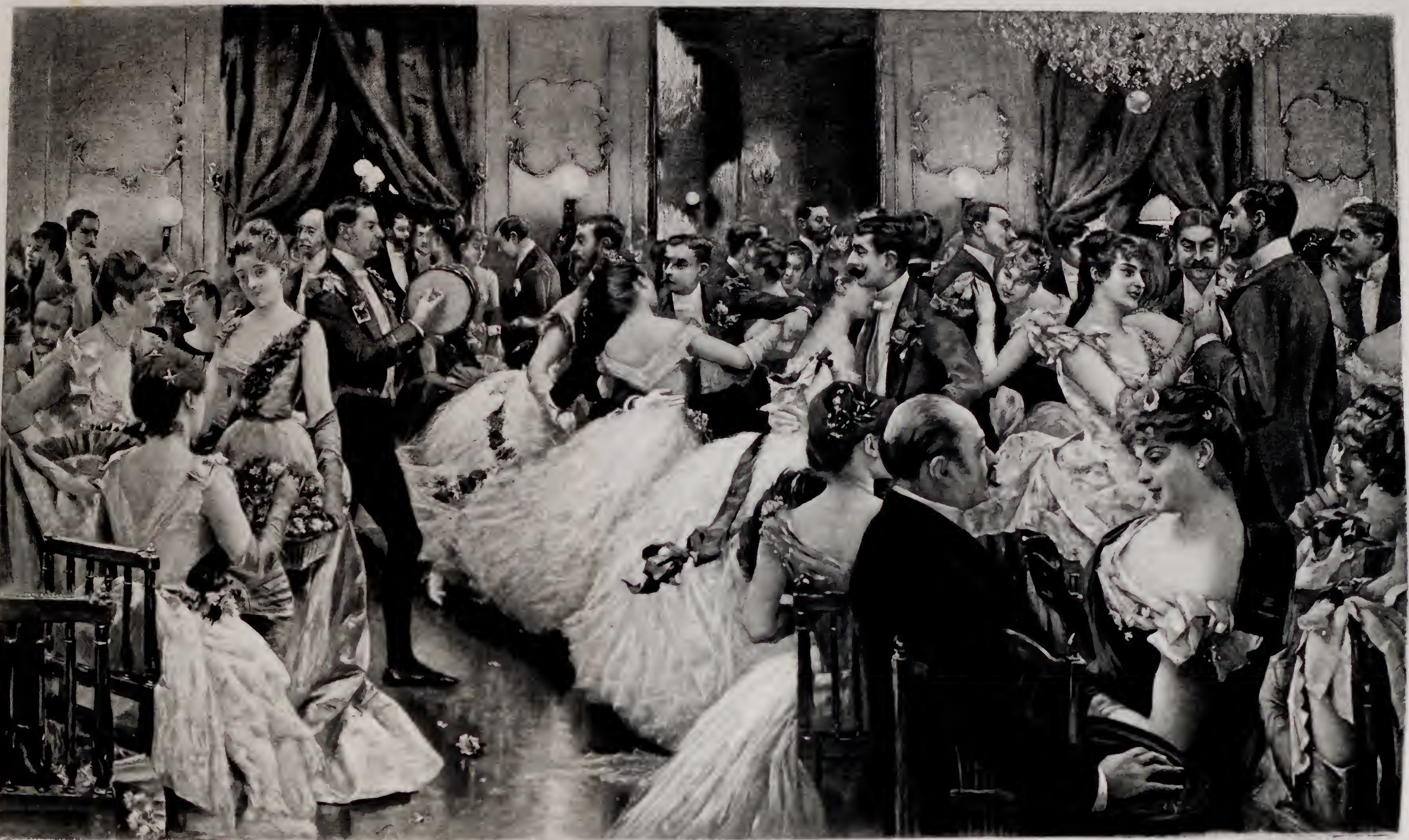




\section{SELECTED PAINTINGS}

FROM THE

\section{PARIS EXHIBITI0N, 1889}

A COLLECTION OF 33 PHO'TOGRAVURES FROM THE MOST ADMIIRED PICTURES

WITH DESCRIPTIONS

BY J. F. REED, A. M.

AND OTHER WRITERS

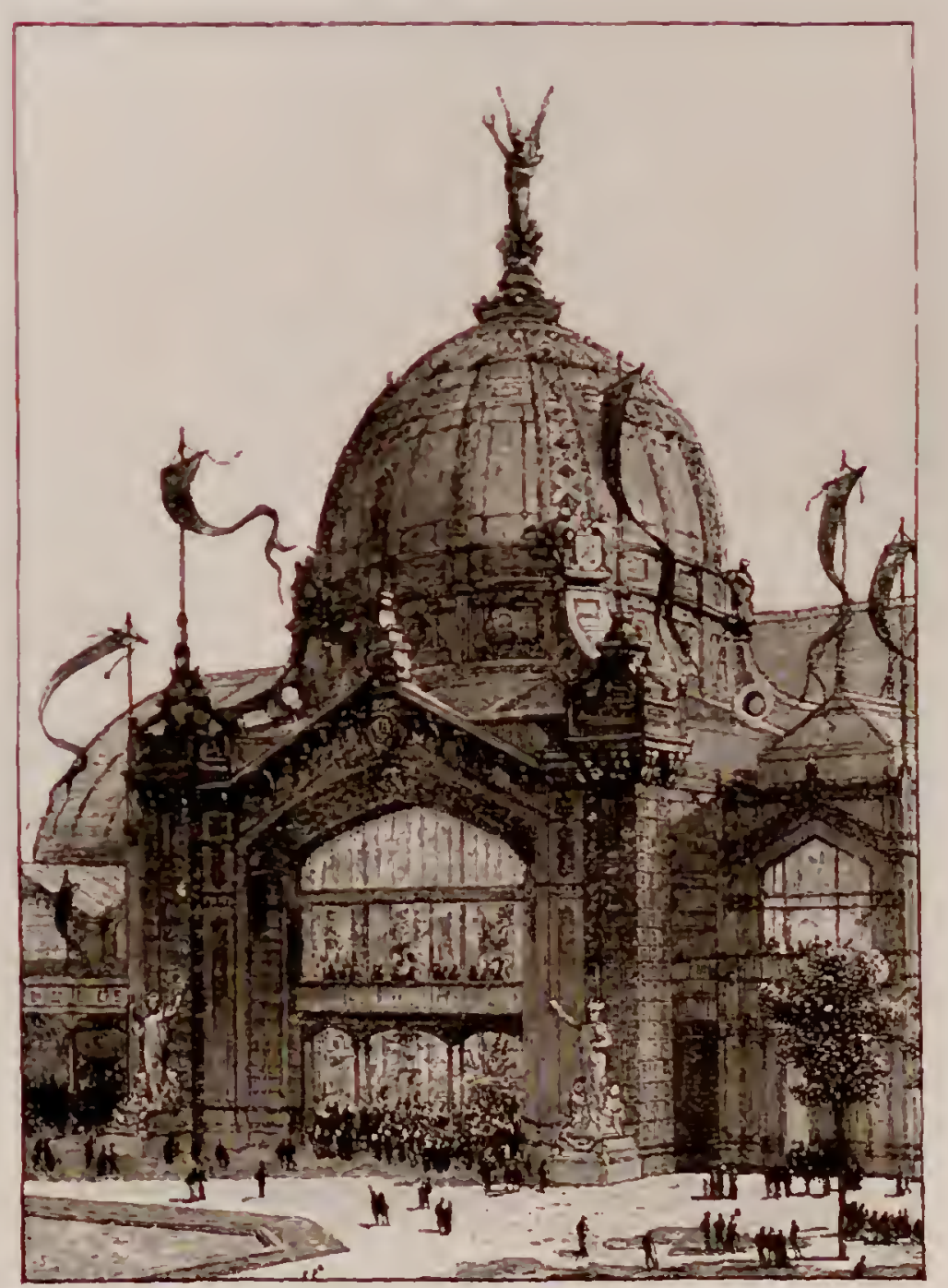

PHILADELPHIA

GEBBIE \& CO., PUBLISHERS 
Germany has a small exhibit: Keller, Bochman, Liehermam, Menzel, Kuch, Meverhem, we. Rusi.

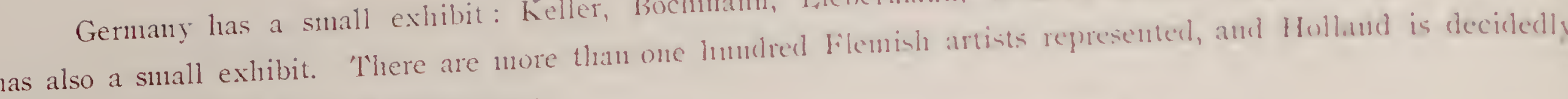
in the front rank in the Art Department.

Sweden sends the works of Zom, Kronthen, Ekström, ()iterlind, Haghore, Lamsen, ctc

Norway sends Peterson, Werenskiold, and delightul landscapes and marines by Nommm

Greece has a small exhibit by Ralli, Sigalas and Jacobiless; the latter has one of the pretticat pictures in the whole collection. The title is An Agrecable kerding-two sweet, pretty girls reading a book

The American exhibit is inferior to what it might have been, had there existed mure hannony anong the is best artists as to how it was to be represented, and by what pictures, and by whom. So we hroe to mote a vers minor representation of the artists of Anerica; but, such as it is, it doces Anerica credit. do more than name the most noticeable paintings, as we think, in the orier of nerit, commencime with This.

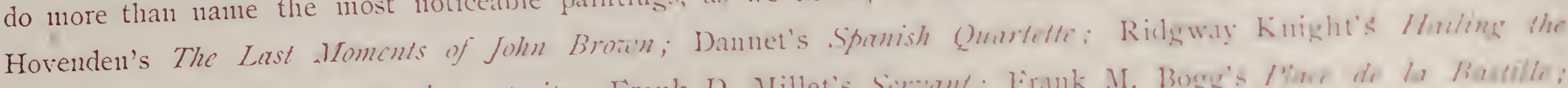

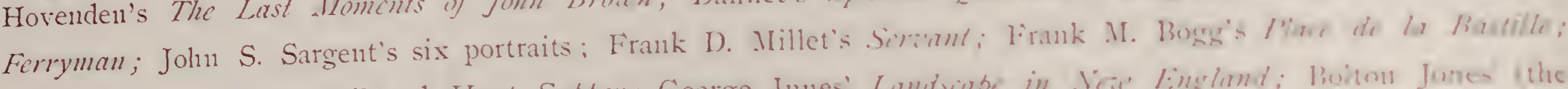

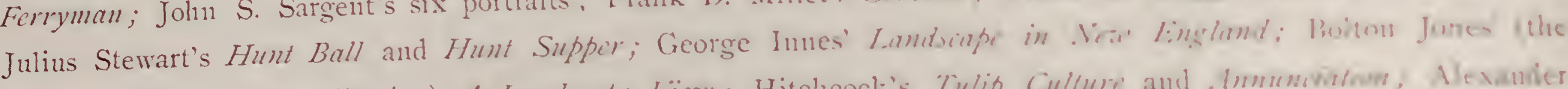

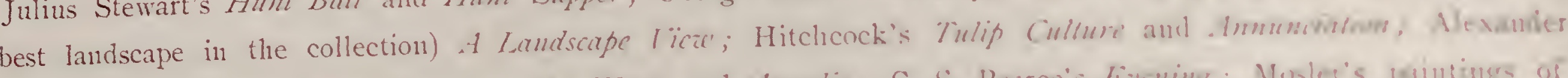

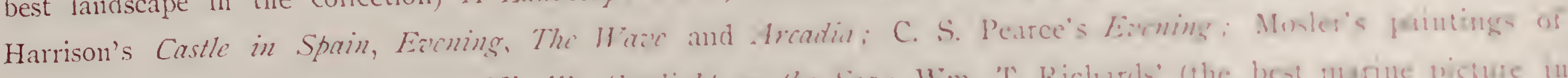

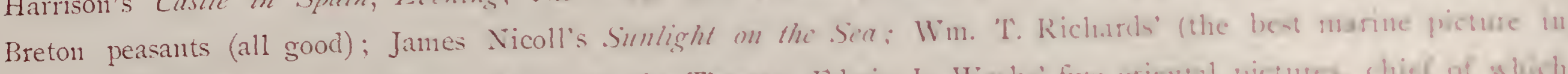
the exhibit) After a Storm; Engene Vail's On the Thames; Folwin L. Noeks' five uricutal fricuses, chief of alink is The Sacred Lake. Henry Bacon and Walter Gay conld have sent much better picture- ll wher finshes conld

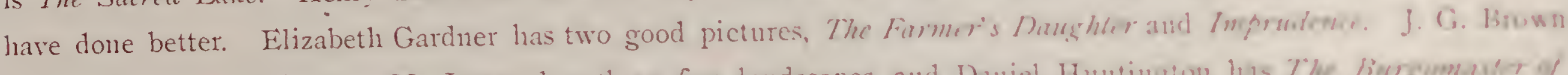

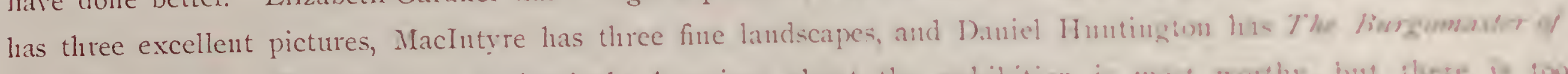
New Amsterdam. What there is distinctirely American abont the exhibition in mon woths, hut ilere in ton

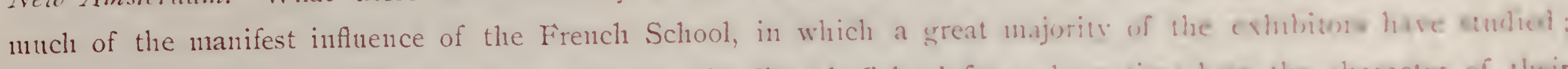
but this will have to be borne for a time, just as the Firench School for a lumg time bore ine chandes of ilueis early teachers-the Italians.

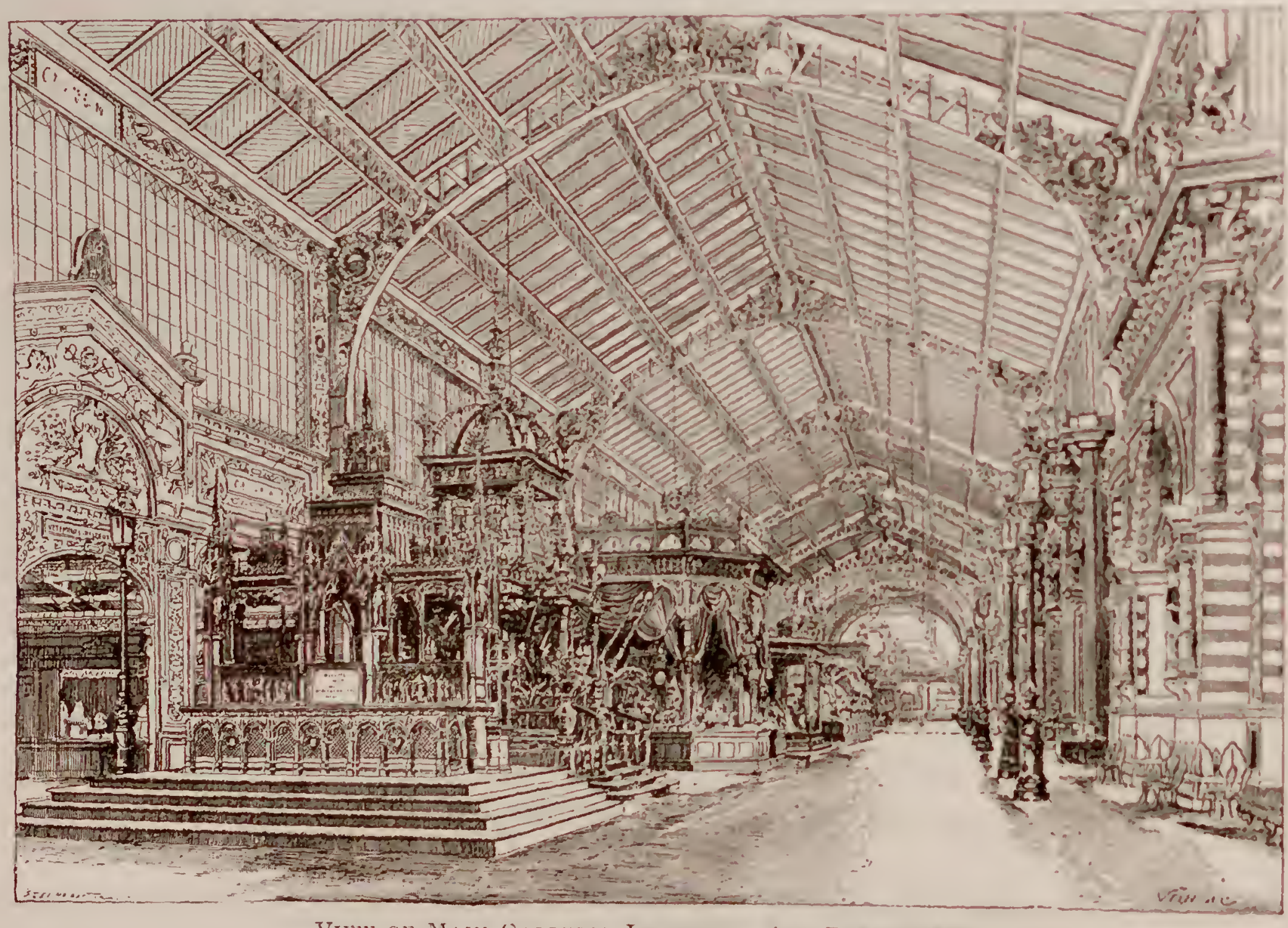

VINW OF MAIN CAALRRY, INDTSTKIAR, ART DEBARTMGNT. 


\section{List of Photogravures}

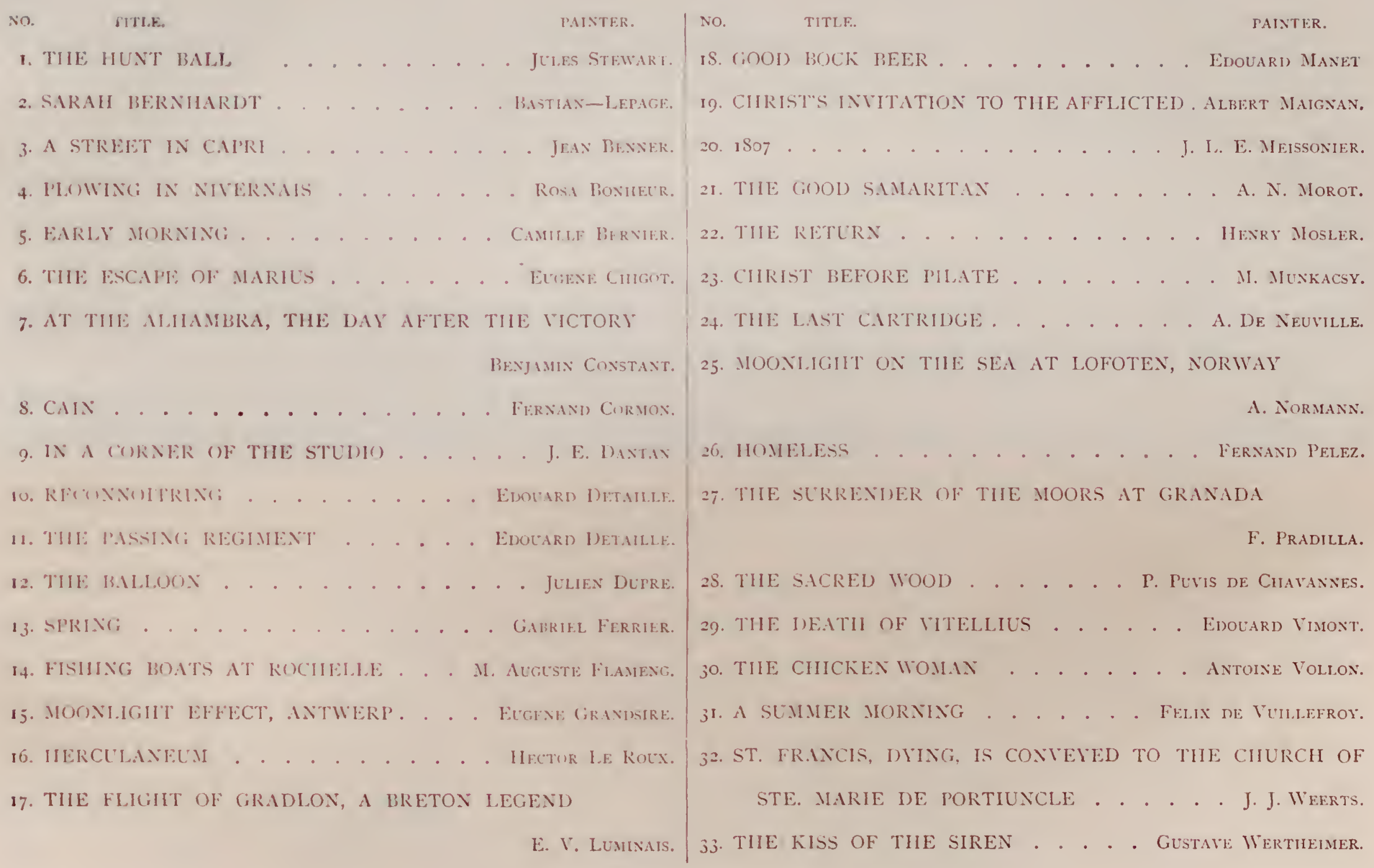





\section{The Hunt Ball.}

PHOTOGRAVURE FROM THE ORIGINAL PAINTING BY JULES STEWART.

(AMERICAN SCHOOL.)

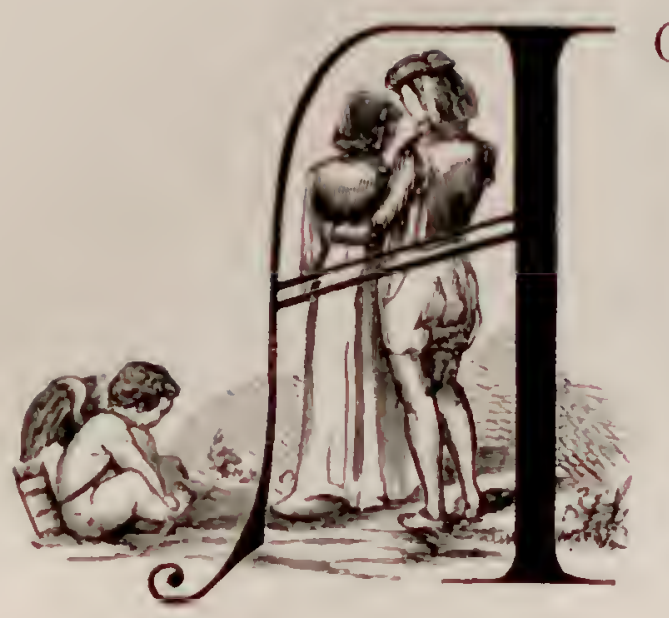

GAY and festive scene in gay and festive Paris, painted by an American artist, although his whole education, artistic and otherwise, has been in France. The painting of The Wedding Breakfast, which was owned in Philadelphia, first brought young Stewart into notice as a brilliant colorist, who depicted high life or society with a graphic power. A ball given by the members of a Huxt has been an English custom for two centuries, and, next to the County Ball, was an institution for match-making and general enjoyment. France in this instance, copying from England, adopted horse-racing and fox-lnnting, and with then the Hunt Ball. All the gentlenen "members of the hunt" wear the costume of the lnunt, generally red, the particular decoration distinguishing the members being a peculiar button, with which only members are privileged to deck their coats and vests.

Of conrse, only the wealtiy and privileged classes can afford to be members of THF HuNT, and the scene of the painting is therefore HaUT Tox. It affords the artist an excellent opportunity for brilliant contrast of colors and elegance of costume, in which Mr. Stewart in this instance has really excelled himself.

Jules Stewart was born at Philadelphia, and was a pupil of Gerome and of the Spanish masters, Zamacois and Madrazo. He is one of the leading painters of the American colony at the French capital. This painting, which belongs to the Metropolitan Museum of New York, is a noted feature of the Paris Exhibition, ISSg.

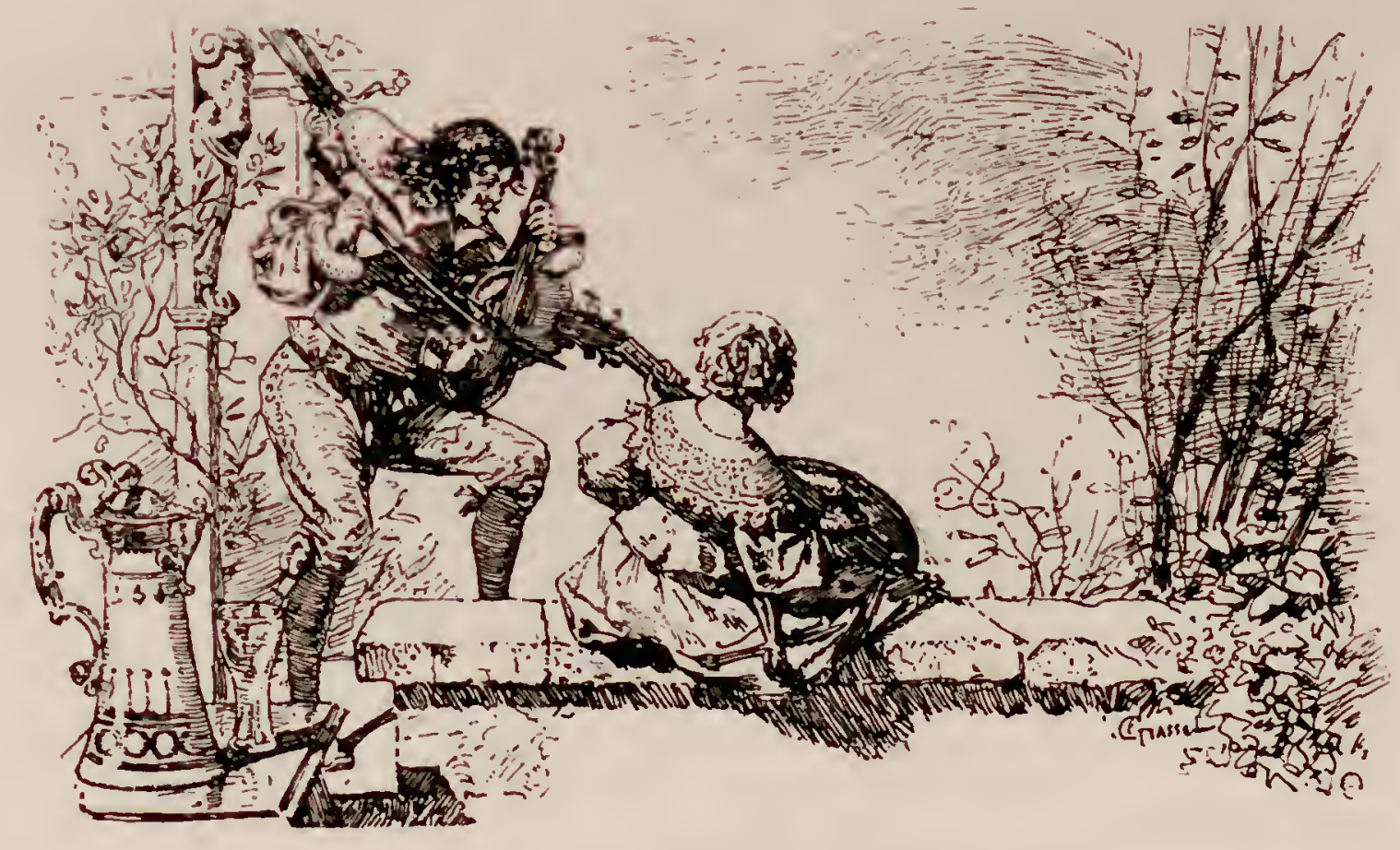






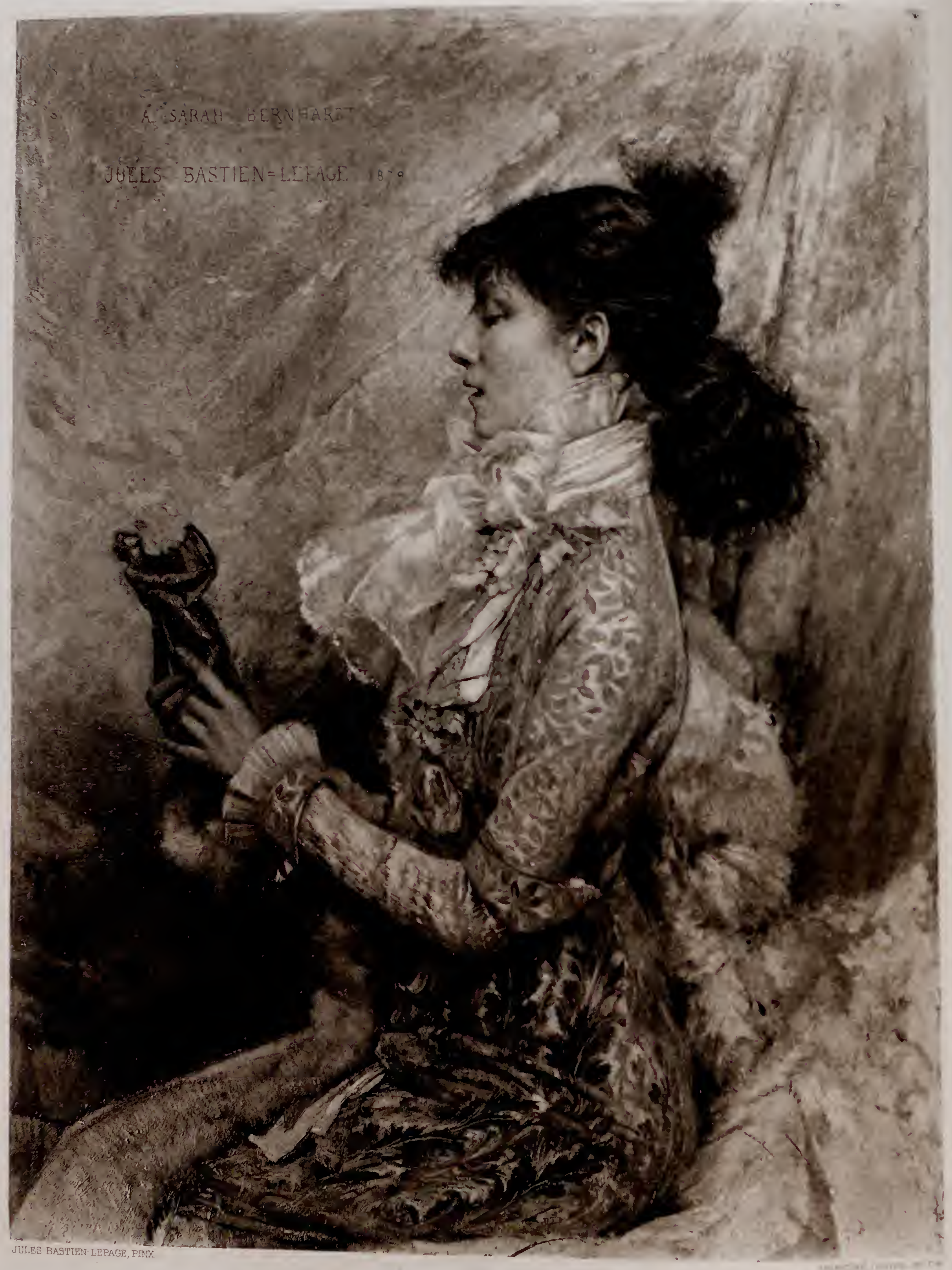




\section{SARAH BERnHARDT.}

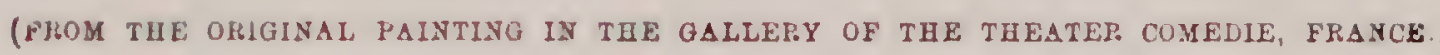

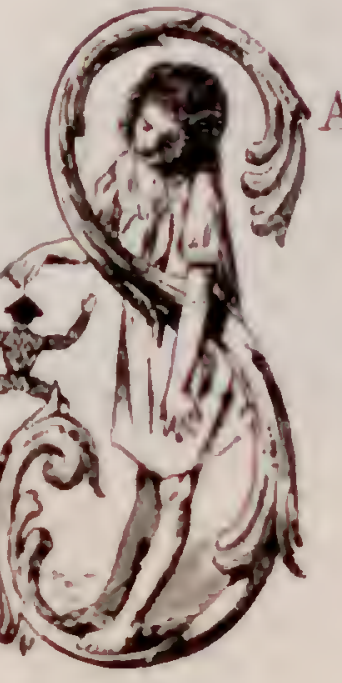

ARAH BERNITARDT, whose recent visit to the United States must be fresh in the memory of many of our subscribers, was born at Paris on the $22 d$ day of October, 1844. Her parents were Hollandaise Jerrs, but she was baptized and educated in a convent; she commenced her career on the stage in her fourteenth year, and has ever since held a proninent position.

She has aloo achieved some distinction as a painter and sculptor, but we question very much whether she would ever have been heard of in either, had she not been famous as an artist on the mimic stage. She holds in her hand a clay model of a piece of scalpture which she is moulding.

The great portrait painter, J. Bastien-Lepage, was born at Danvilliers in 1846 . He entered the sturlio of M. Cabanel in 1968, and speedily showed his great talent. He was represented in the Exllibition of 18,75 by four paintings, where he received a first class medal and decoration of the Legion of Honor, haring previously, in 1874, received a third class medal, and in 1875 a second class. Mademoiselle Bernhardt's portrait was painted in 1879. 




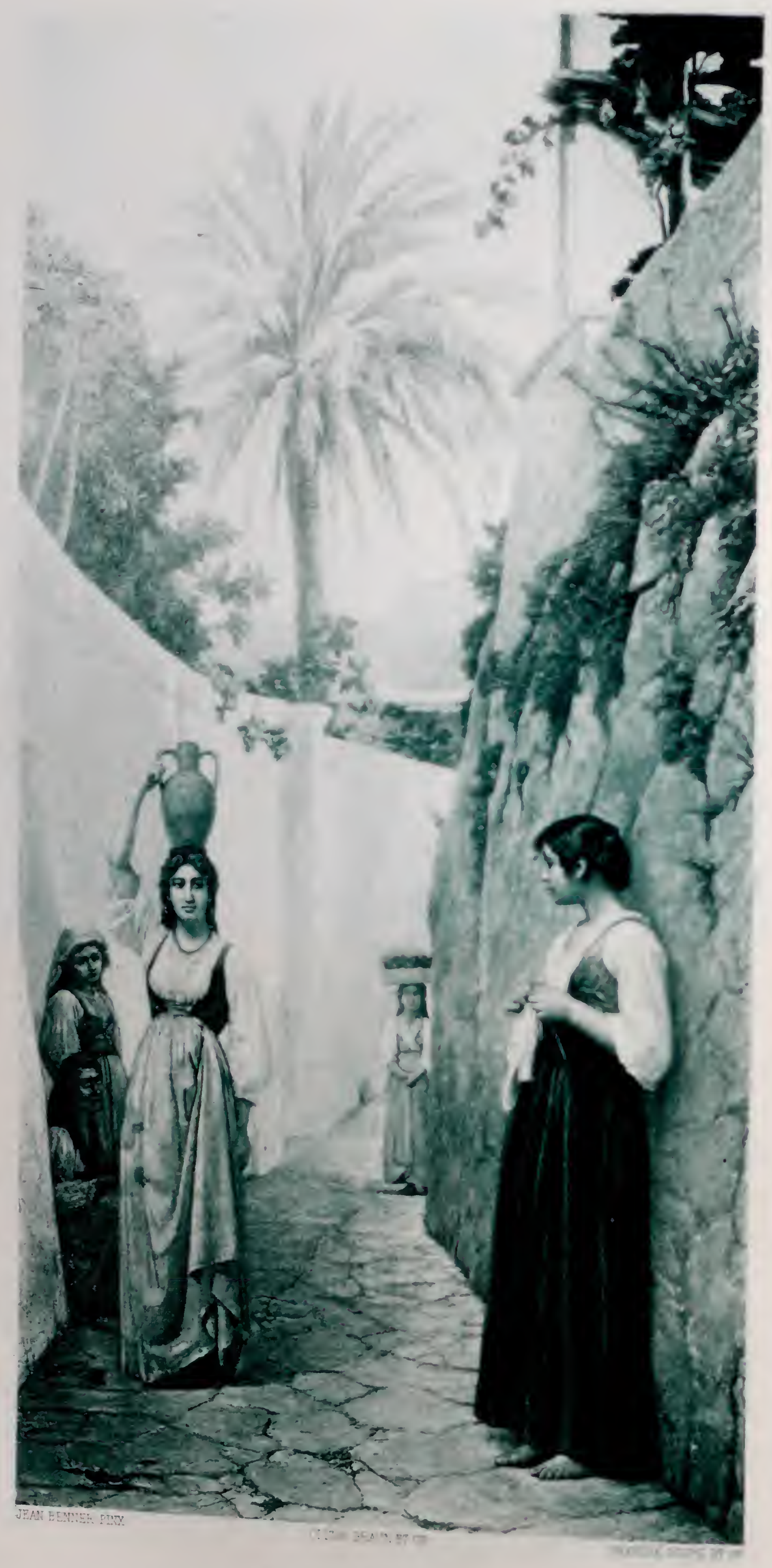

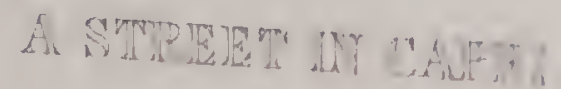




\section{A Street in CAPri.}

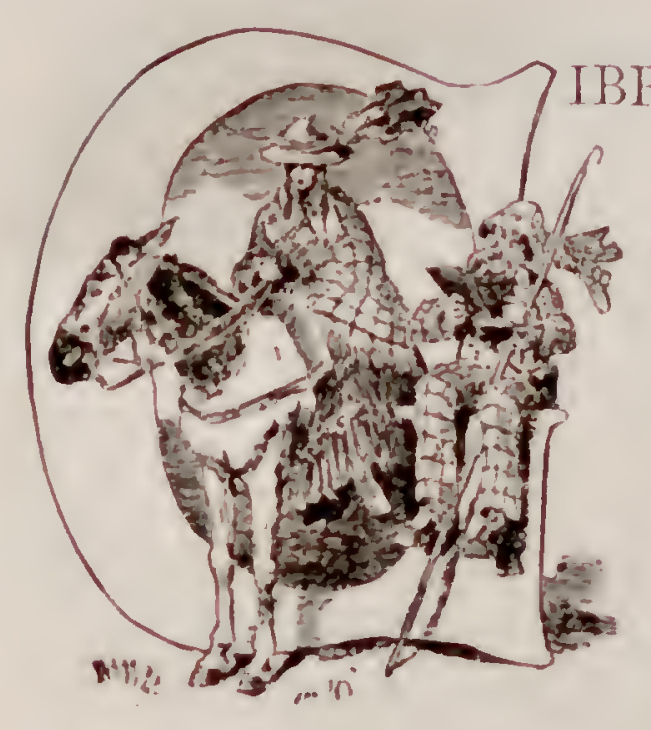

BRALTAR-like in its conformation is the historic island of Capri. Like the mountain range which forms the southern boundary of the bay of Naples, and of which it is, in fact, only a continuation, Capri consists wholly of limestone, and is girt almost all round with precipitous cliffs of rock rising abruptly from the sea, and in many places attaining a great elevation. The western portion of the island is much the highest, rising to an altitude of 1600 feet above the sea. The eastern end also forms an abrupt hill, with precipitous cliffs towards the mainland; but between the two is a depression, or saddle, of moderate height, whereon stands the modern town of Capri.

The only lanting-platers are two little cores on either side of this.

little is known of the history of Capri prior to the time of the Emperor Augustus, who, having taken a faney to the island, obtained possession of it as a part of the imperial domain, in exchange for the wealthice island of Enaria. Cayri, however, owes its chief celebrity to the Fmperor Tiberius, Who, in A. D. 27, made it his permanent residence. Here, secured alike from observation and danger by the inacusithe character of the spot, Tiberius abandoned limself to those gross debaucheries which, addeal to his cruelties, have inade lis memory eternally detestable. The remains of several of the twelve sumptuons villas that he erected on the island are still risible. This island was also the scene of the banishument and deatls of two Roman Empresses. One of these was Lucilla, widow of the Emperor Jucius Verus and sister of Commodus; the other was Crispina, wife of the Emperor Commodus, of whose rengennee both women were the rictims.

Capri is well known to modern travellers by the "Blue Grotto," a wonderful cavern to the west of the town, entered from the sea by a narrow opening about three feet high. Inside, however, it is of magnificent proportions, and of marvellous beauty, the rich blue color being produced by the reflection and refraction of the sun's rays through the water.

M. Benner's picture agreeably suggests the picturesqueness of the Caprian scenery. The palm tree and the warm sunlight, witness to a semi-tropical climate; while the narrow streets and solid walls of rock, tell of cool shadows. The charm of pose so often remarked in the Italian peasantry, is exemplified in the comely girl who advances towards us, carrying a vase on her head. In Italy the dwellings of the poor are not comfortable, and here, as on the mainland, the people spend much of their life out of doors, - as we are reminded by the girl knitting, and the old woman seated, by the roadside.

M. Benner is a native of Mulhouse, Alsace, and studied under Pils. In 1872 he received a medal of the second class. A Street in Capri was exhibited in the Salon of 1880. 




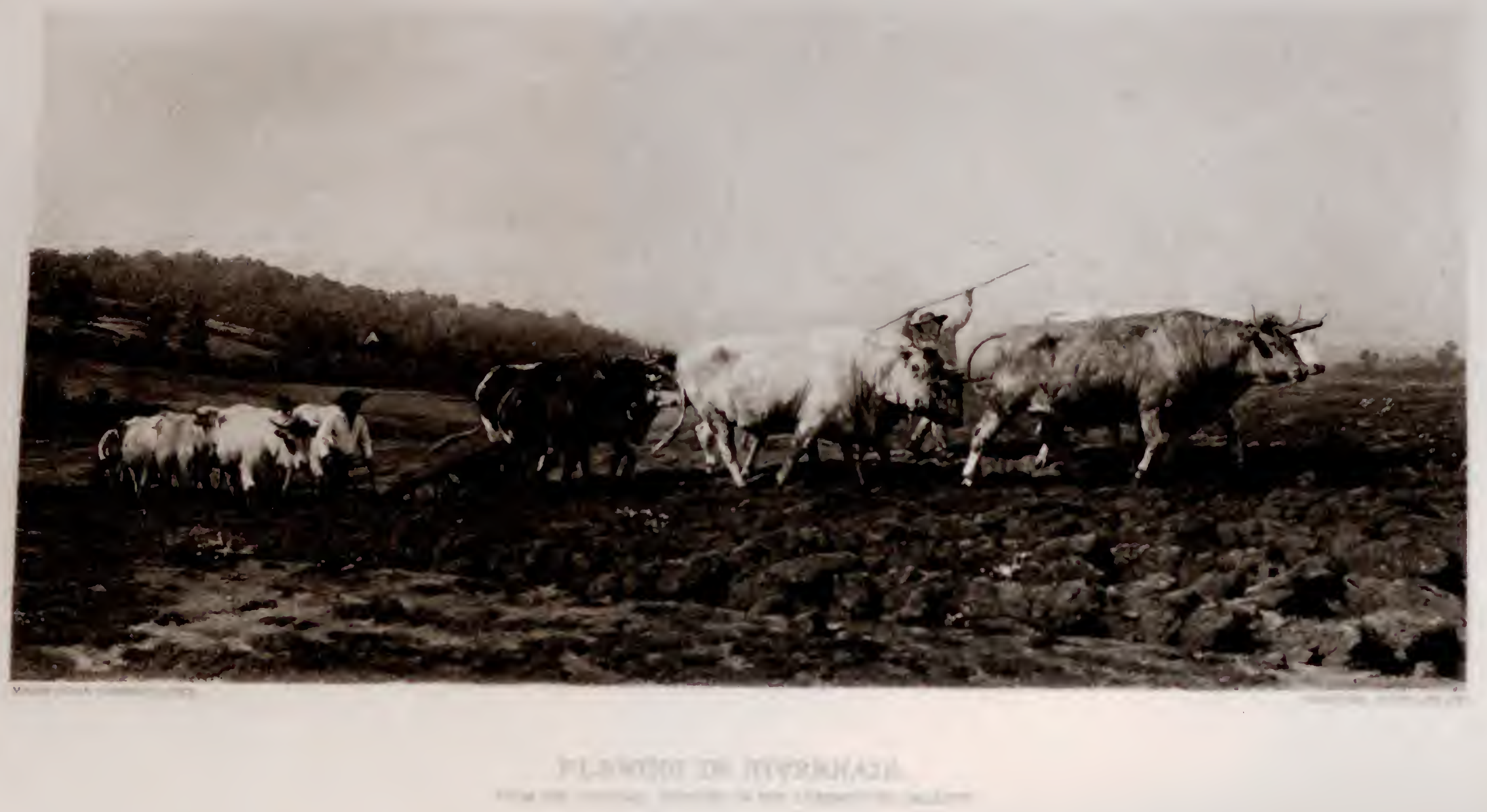




\title{
Ploughing in Nivernais.
}

(FroM THE ORIGINAL PAINTING IN THE LUXEMBOURG GALLER.)

Goupil \& Co., Gravure.

\begin{abstract}
俈
Ihis pirture wo cannot do better than quote Mr. Hamerton's enthusiastic description :

"I hear, as I write, the cry of the ox-drivers-incessant, musical, monotonous. I hear it not in imagination, but coming to my open window from the fields. The morning air is fresh and pure, the scene is wide and fair, and the Autumn sunshine filters through an expanse of broken, silvery cloud.

They are ploughing not far off with two teams of six oxen each-white oxen of the noble Charolais breed-sleek, powerful beasts, whose moving muscles show under their skins like the muscles of trained athletes. Where the gleams of sunshine fall on these changing groups, I see in nature that picture of Rosa Bonheur's Ploughing in Nivernais."

There is a touching anecdote in connection with this picture. Her father, also an artist, when on lis death-bod, and feeling his end approaching, desired to see his already famous daughter's latest work, and there was brought to his bed-side, Ploughing in Nivernais. The dying artist beheld AND WEPT. A silent tribute, it is recorded, nnore prized by his daughter than all the world's applause in ufter years.
\end{abstract}






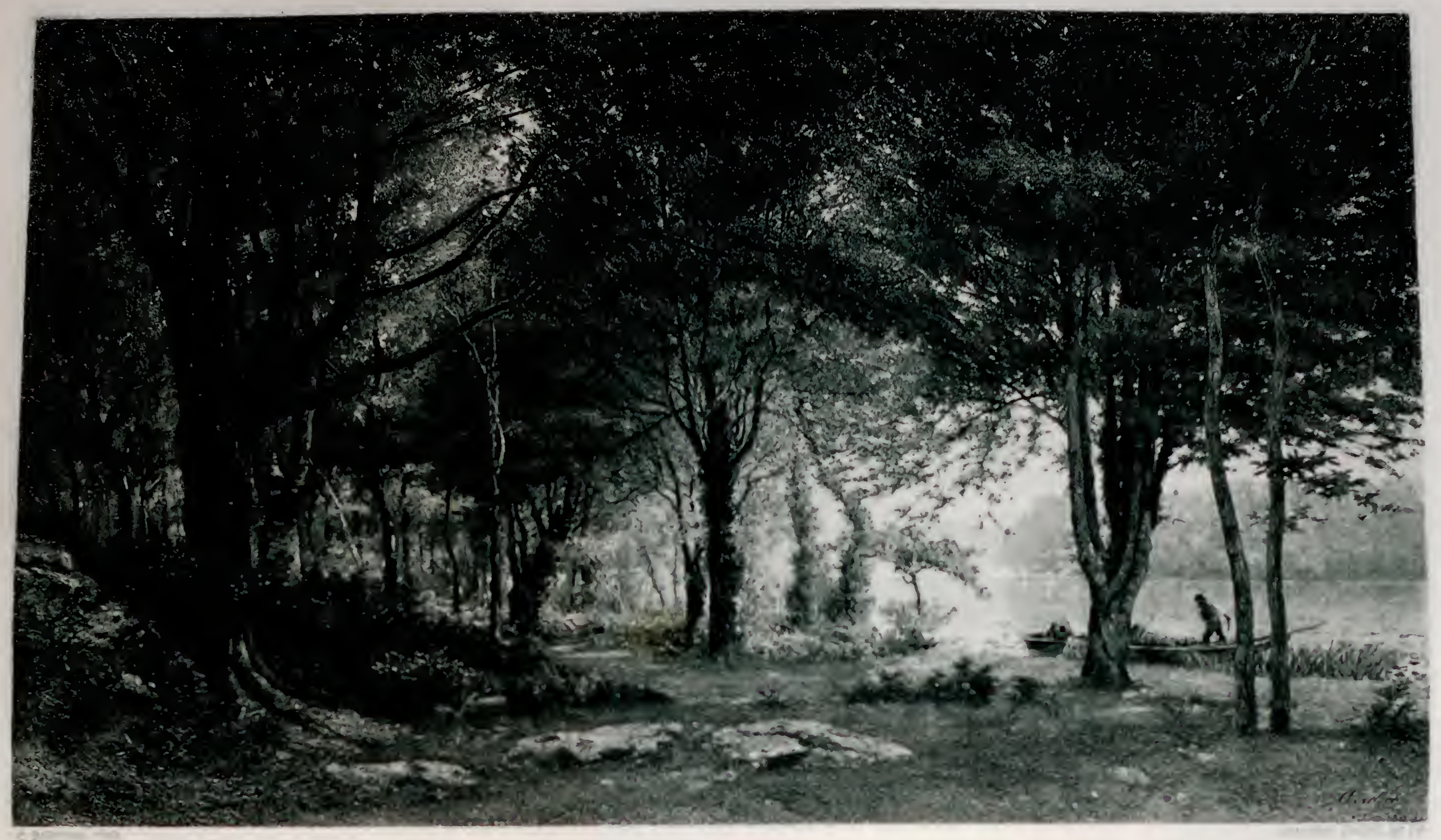




\section{Early Morning.}

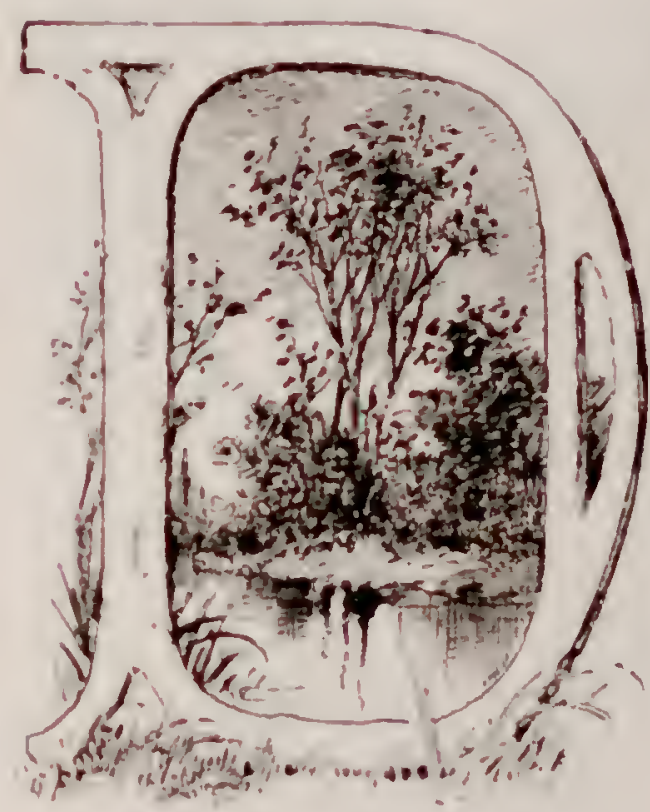

AWNING and declining day have each their peculiar charms. Those of erening are most familiar, and no poet, either of the brush or the pen, has ever exhausted the lovely theme,-few indeed have risen to its high level. Nature never repeats herself, even in a sunset. Every declining day since creation's dawn has brought some variation of cloud form, some splendor of light, some richness of colors, or some exquisite delieacy of tint melting into the zenith, which no other day has presented; and under these infinitely varied lights the landscape effects delight us with ever-clanging beauty. But, after all, the splendors of sunset are pensive and sal: they mark the departure, not the arrival, the death, not the lijth, of the day. They are like the glories of Autumn contrasted with those of Spring. or like the plaimtive nong of the nightingale opposed to the glad carol of the lark:

The sumrise wakes the lark to sing,

The moonrise wakes the nightingale.

The dawn, therufore, if lese gorgrous than the decline of day, has in it somewhat of the freshness of chilithod and of the exuberance of hope. No sooner does the poet take morning for his theme than lis song grows joyous:

The morn is up again, the dewy morn,

With breath all incense and with cheek all bloom,

Laughing the clouds away with playful scorn,

And liring as if earth contained no tomb,

And glowing into day.

M. Bemier's picture places before us one of the loveliest scenic combinations in nature, viz., a rustic path, canopied by interlacing bougls and bordered by a placid stream. With what delicious softness and warmth the light permeates the leafage, and low dreamy the beauty of the golden mist that melts under the increase of the ascending sun! Though it be toil that calls lim thus early forth, we enry the bontman the privilege of labor in such beautiful surroundings. Camille Bernier was born at Colmar in 1823, and was a pupil of L. Fleury. He holds an honorable place among the brilliant landscapists of France. His Jamuary is in the Museum of the Luxembourg. The present picture was exhibited at the Salon of 1880. He received Salon medals in 1868 and 1869 , and a second-class medal at the Universal Exposition of 187S. He is a Chevalier of the Legion of Honor. 




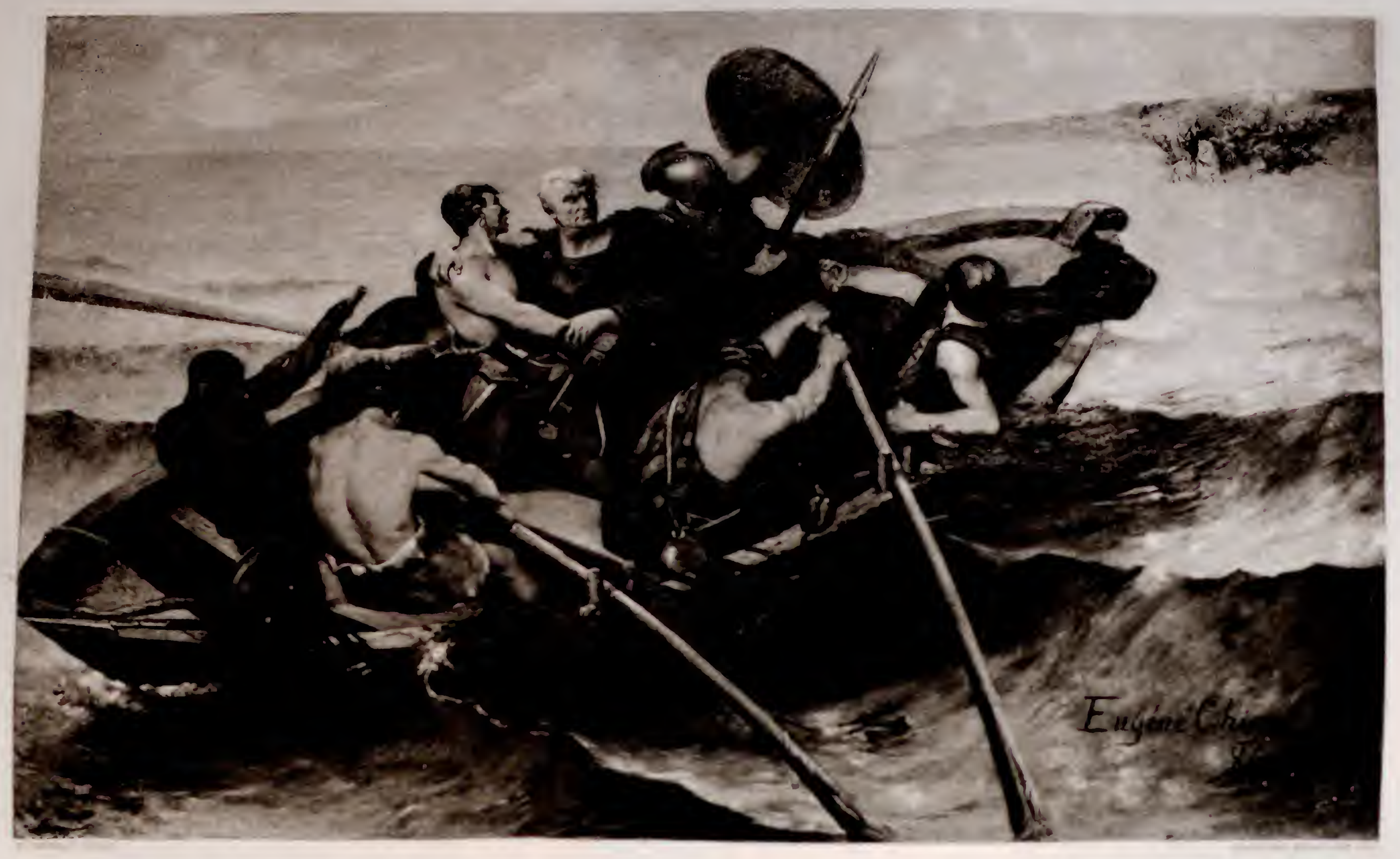




\title{
The Escape of Marius from the Cavalry of Sylla.
}

PHOTOGRAVURE FROM THE ORIGINAL PAINTING BY E. CHIGOT AT THE PARIS EXPOSITION, 1839.

(FKEACH SCHOOL.)

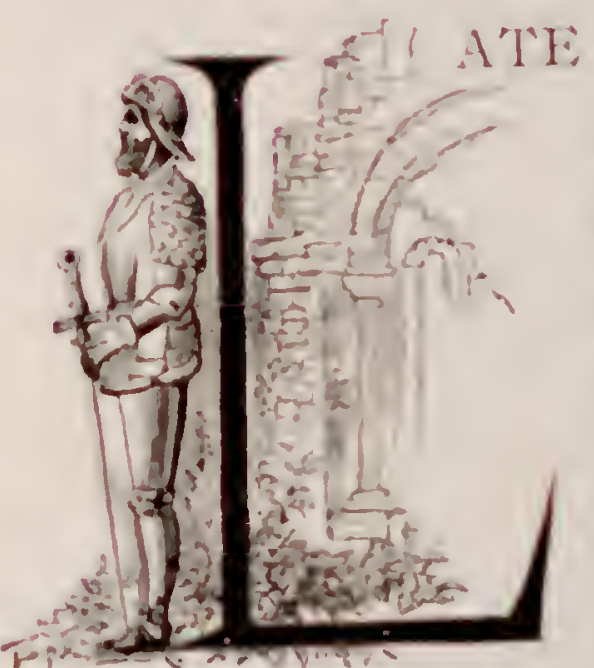

111 the year 90 B. C. Marius and Sylla originated the first civil war in the Ronnan Republic. Marius at the beginning, being Consul, held the highest power in the state. Sylla, however, suddenly came to the front because of his successes as a general, and became the rival of Marius, who as Consul and Senior Cencral sent forth a connmand to Sylla to turn over his army to another. Sylla caused the messenger to be stoned to death, and marched with his army on Ronle, which, after a serious contest, he captured, and declared himself Consul, causing Marius to seek safety in flight. He reached Ostia in company with Granius, his step-son, and a few slaves: hence they proposed to take ship for Africa, where Marius had much infuence. But a stress of weather caused the old Consnl to land near Circii, where he was nearly captured by a squad of Sylla's caralry; but, being warned by some herdsmen of his danger, he had only time to put to sea in an open boat when his enemies dashed into the surf in pursuit. This is the scene of the picture, which was first exhibited at the Salon of 1886 , and was purchased by the state for a permanent place in the MInsem of Valenciennes.

Engene Chigot was born at Valenciennes about I 850 , studied art under Cabanel and Vayson, and is recognized in Paris as a historical painter of great promise.
\end{abstract}

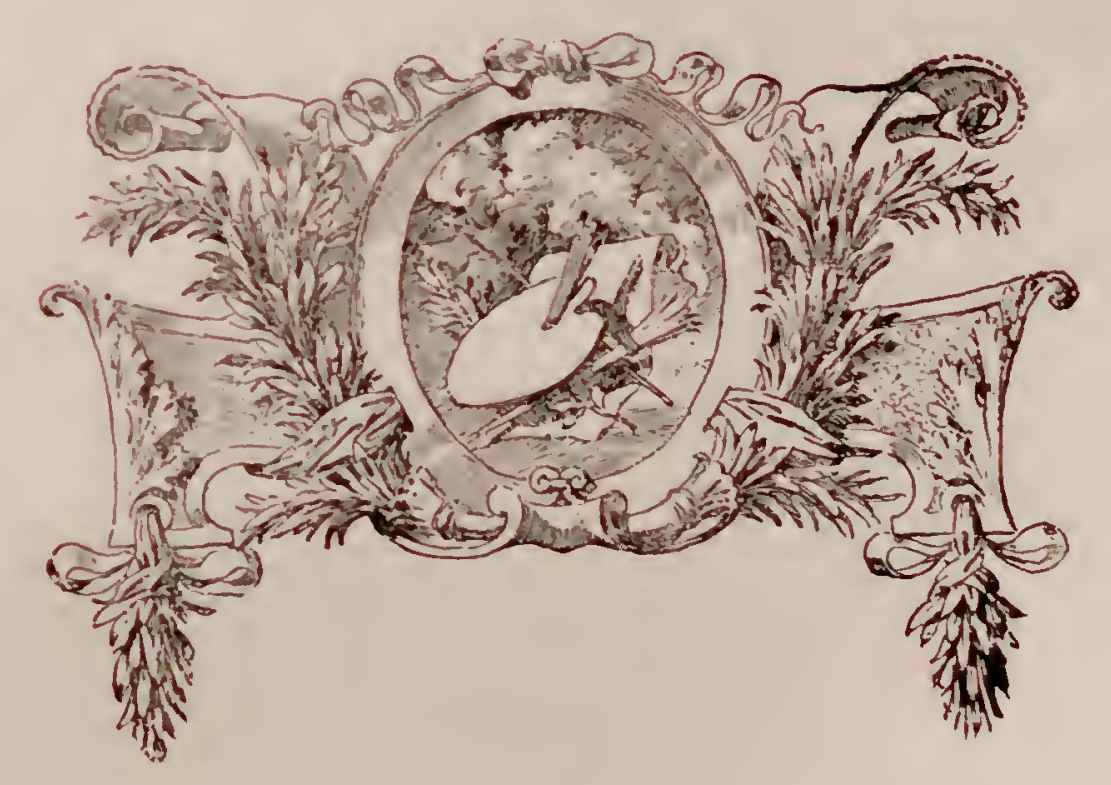





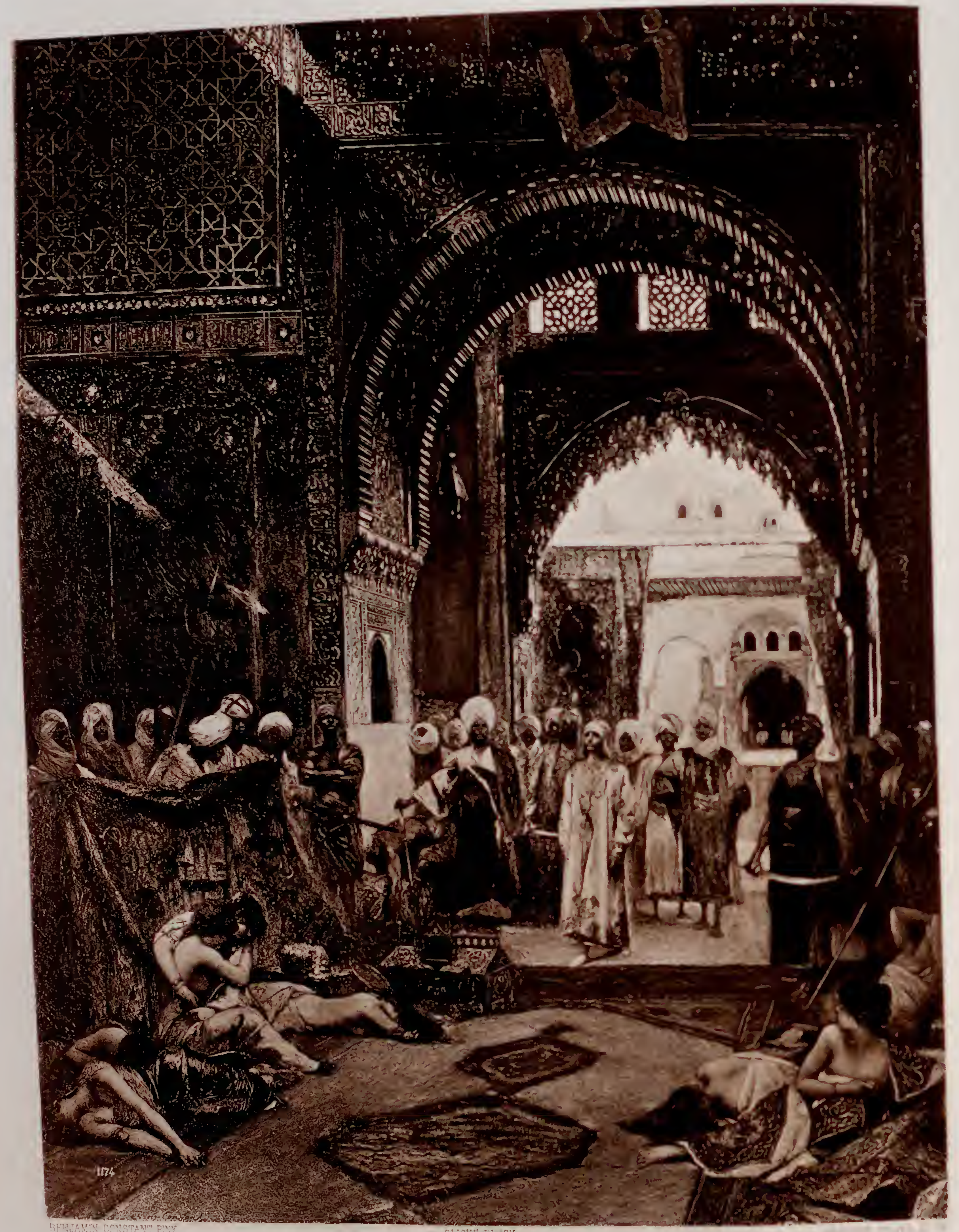




\section{At the Alhambra the Day after a Victory.}

Benjamis Constast, Pinx.
Goupil \& Co., Granure.

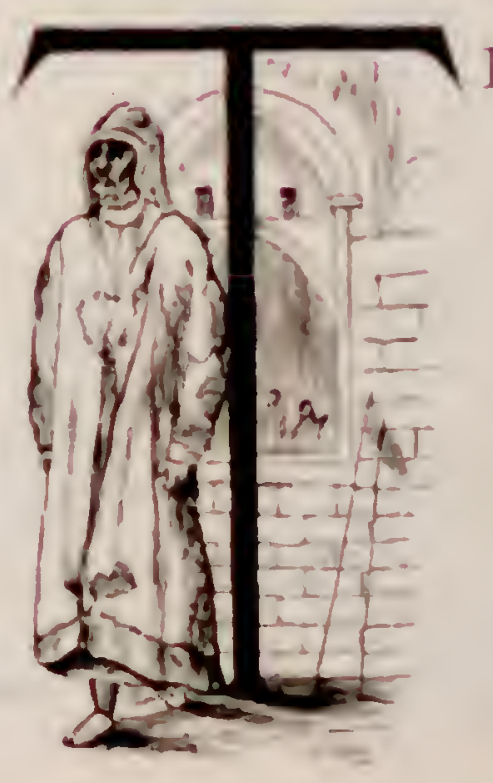

HIS scene transports us backward to the time when that wonder of art, the fortresspalace of the Alhambra was yet in its glory, and when the Moors still held dominion in Spain. At this time, however, the Christians were already making rigorous cfforts to regain the ascendant, and the conflicts betreen the rival powers were frequent and sanguinary. The artist has vividly pictured a characteristic accompaniment of a Moslem triumph. The rictorious Moor comes forth from his chamber the morning after the battle to surrey the booty which has been biought together in a hall of the Alhambra. Brilliant stuffs, jewelled arms, glittering gold and silver plate, are here in profusion; but of higher esteem are the female captives, from whom he will make selections for his harem. The hapless maids, torn from Christian home- amint their shameful fate in erery attitude of grief and despair. The expressions and grouping of all the actors in the drama are most effective and truthful, and the care larished on the splenlid architectural setting make us regret the absence of the colors which impart extraordinary richnes to the original. It has been well said that this picture of the triumph of a Moorish king might, with equal truth, be called the triumph of Benjamin Constant. It was exhibited at the Salon of 1892 .

Although a young man (born in 1845). M. Constant has already earned a great reputation. He studied under Cabanel, and male his clebut at the Salon of 1869 with "Hamlet and the King," which was purchased by the government. He obtained a medal of the third class in 1875 , one of the second class in 1S76, and one of the third class at the Unirersal Exposition of 1878 . In the latter year he also received the decoration of the Legion of Honour. 


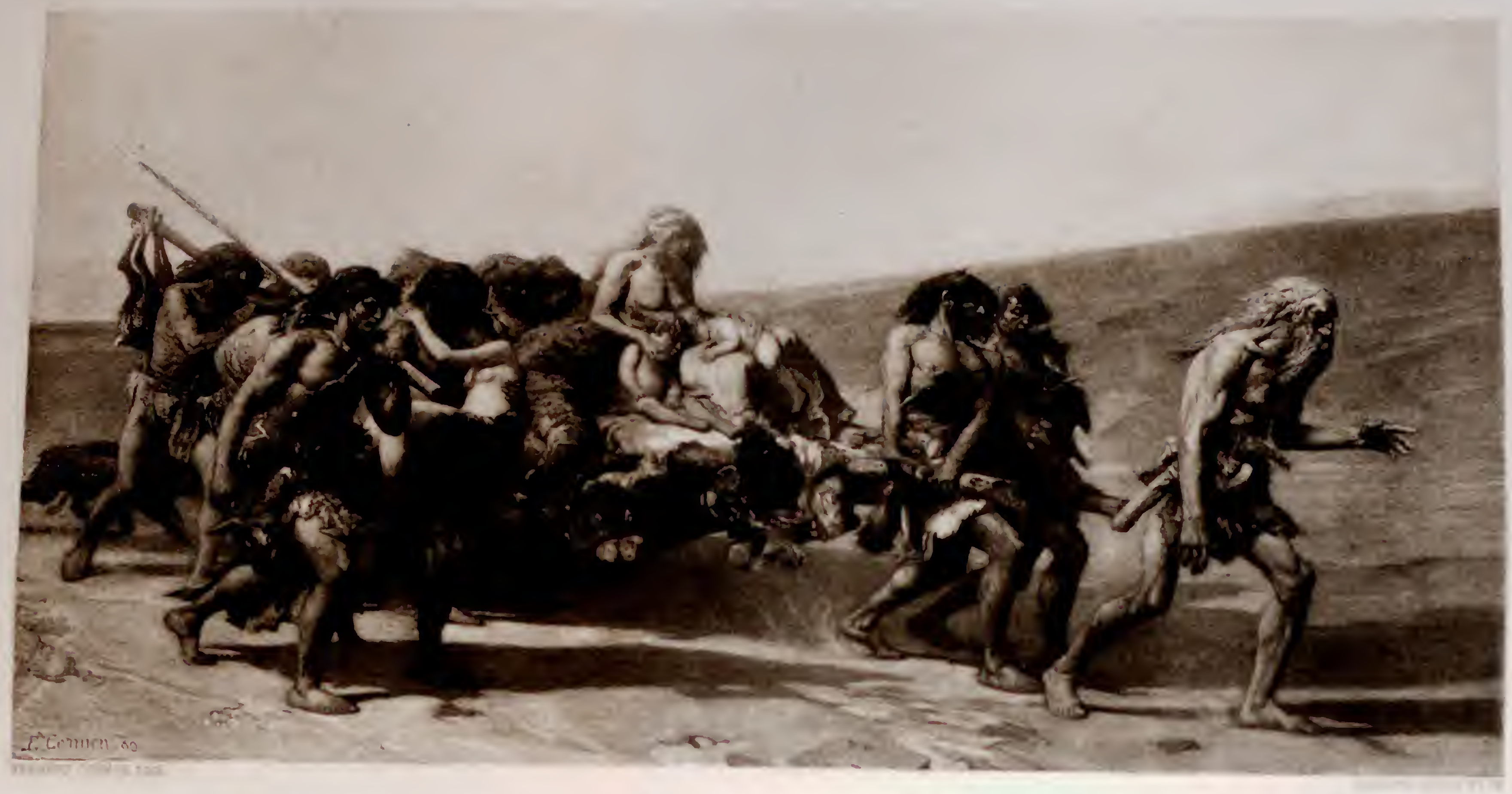




\section{CAIN.}

FroM THE ORIGISAL FAINTTNO IN THE LTXEMBOTRG GALLFRY.

Goupil \& Co., Gravure.

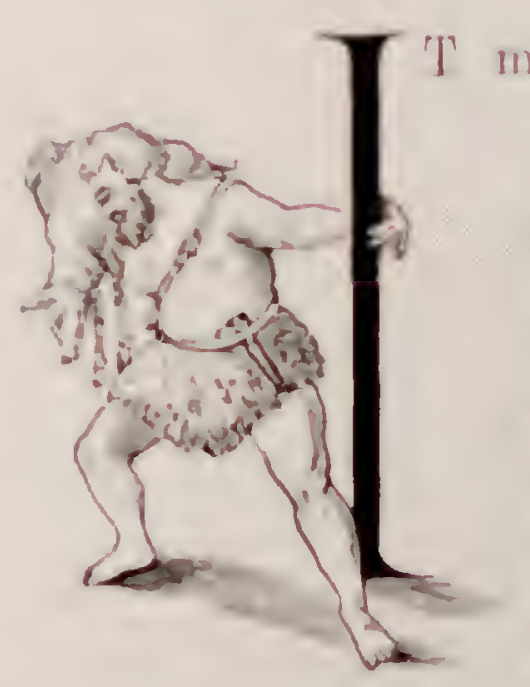
might at first glanen seem difficult to fix the period of time depicted in this farsige frum the listory of the first destroyer of human life. The popular impresion asmociates Cain's murder of his brother with their earlier years, from the fuct that up to the time of this tragic incident the sacred narrative makes no mention of any other offepring of Adan. But the reference to Cain's wife, which immediatcly follows, makes it probable that the human family had already receiven a considerahle inerease, other children having been born to our lirst parents between the birth of Abel and the birth of Seth; and this idea is sulfuntend by the fear expressed by the murderer in the words, "And it shall comn on pane that "very one that findeth me slatl slay me." As we are told that Cain founded a city in the conntry of his exile, we infere that his "fngitive and ragabond" days were those following close

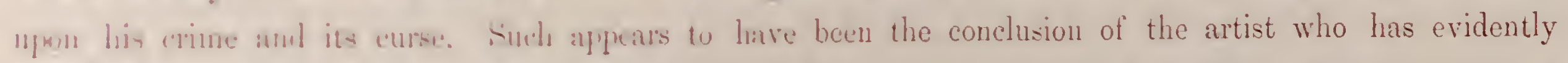
sturlient the sulject with carre. Canin, alrealy adranced in years, is presented as fleeing from the scene of his crime, followinl ly his descendants of two generations. The scene is conceived with originality and power. Cairis comtenance and body alike indicate a troubled and remorseful mind. His family are maxions and depresed. The yomger men are lusty savages of the world's first age. The rude and melancholy conthe mores acrows the dreary landscape with a motion that can almost be seen and felt.

Fermanl Cormon was born in Paris in 1845. Althongh a young man, he is one of the foremost antists of his day. He studied successively with Cabanel, Fromentin, and Portaels. He made his díbut at the Silon of 1870 , and in 1875 he won the Prize of the Salon by his large work, "The Death of Ravana, King of Tanka." "Cain" wals cxhibited at the Salon of 1850. M. Cormon obtained Salon medals in 1870 and 1873, and a medal of the third class at the Universal Exposition of 1878. 




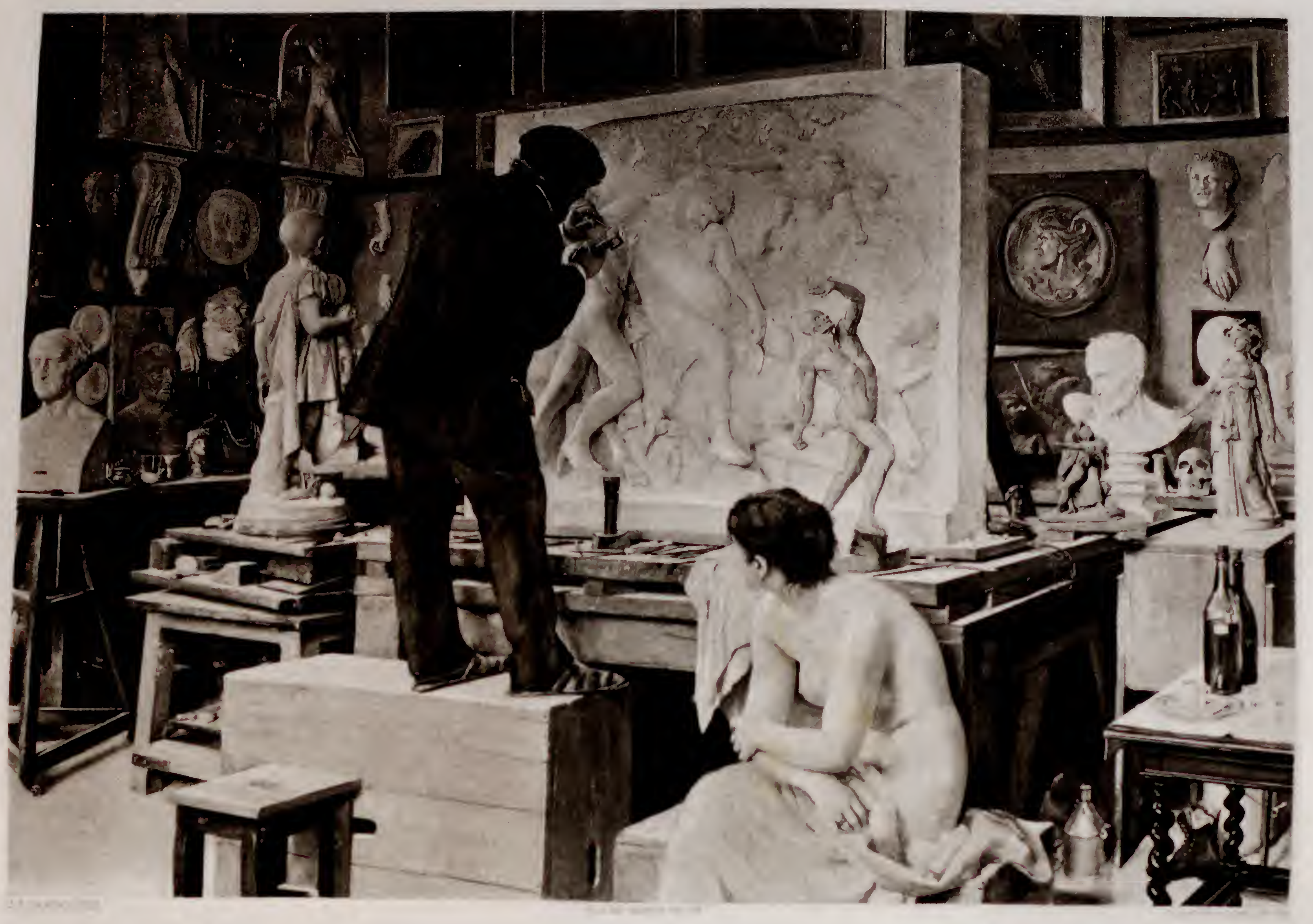




\section{A Corner of a Studio.}

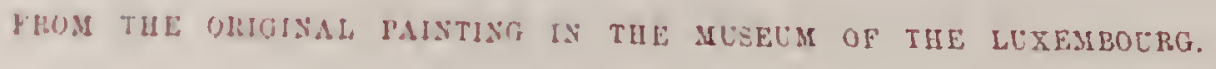

Govpil \& Co., Gravure.

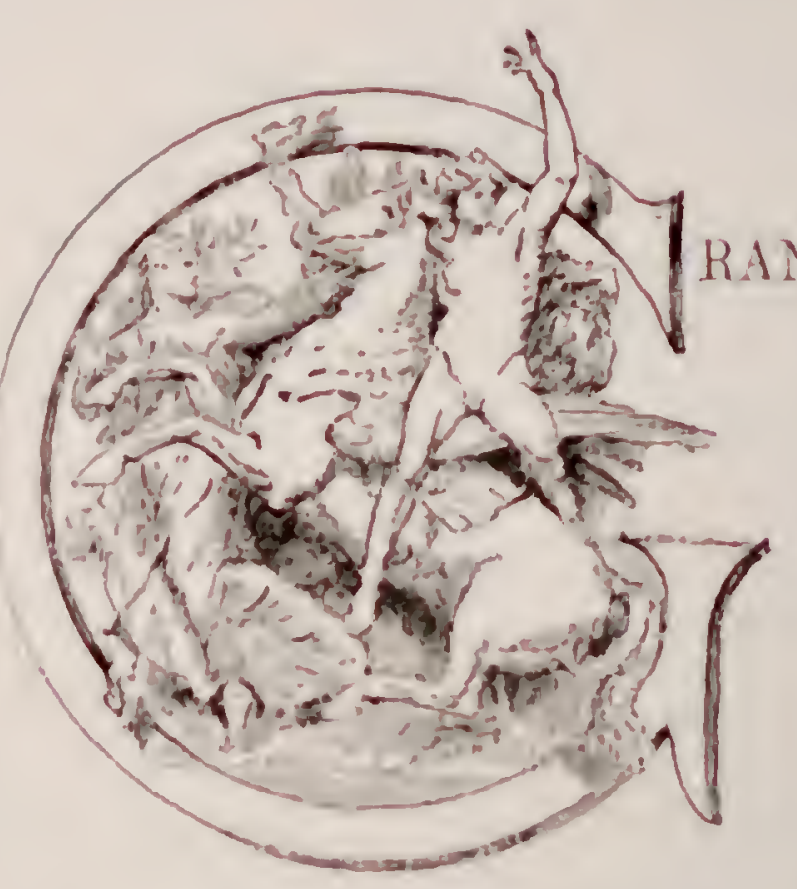

RANDSON, son, and nephew of sculptors, M. Dantan comes legitimately by his artistic gift, although he has diverged from the particular path trolden by his fathers, and has pursued the graphic in preference to the plastic art. The picture before us was undoubtedly a labor of love. The studio, of which the artist shows us a corner, is associated with his childhood and youth, for it is that of his father. Here he spent many happy and profitable hours, and every feature of this apartment, where we may learn of the patience and labor with which the products of the chical are brought to perfection, is fraught with interesting memories. With what fondmes and findulty the form of the futher has been delineated in the familiar attitude of work. The subjont of the relief on which the is engaged will be recognized as that of the drunken Silenus. Below the sculptor sits a gril. who is "moltel" for the nymphs introduced in the Bacchic procession. During on inturnission of praine she watches the skifful operation of the artist, whereby the shapeless marble Irvalually taket on the comblance of life. The small figure above her head, and the skull on the right of the picture angent the anatomical studies of the sculptor; the rarions plaques and masks hung upon the walls are many of them fragments of antique art; the figure of the child on the artist's left, and the various bust thant are here and there seen, represent his work in portraiture. On the little table in the right hand corner, are the tokens of a recent lunch. The picture is crowded with details, yet all are esemutial to the fintlful presentation of the seene, and all are duly subordinated to the central idera, vi\%, the sculptor at work. The painting is a graceful tribute of filial regard. Its technical exconlence, united to pronounced merits of composition and design, secured the recompense of a second class medil at the Salon of 1850 , and the hnor of a place in the Museum of the Luxembourg. M. Dantan studied under MII. Pils and Lehmann. 




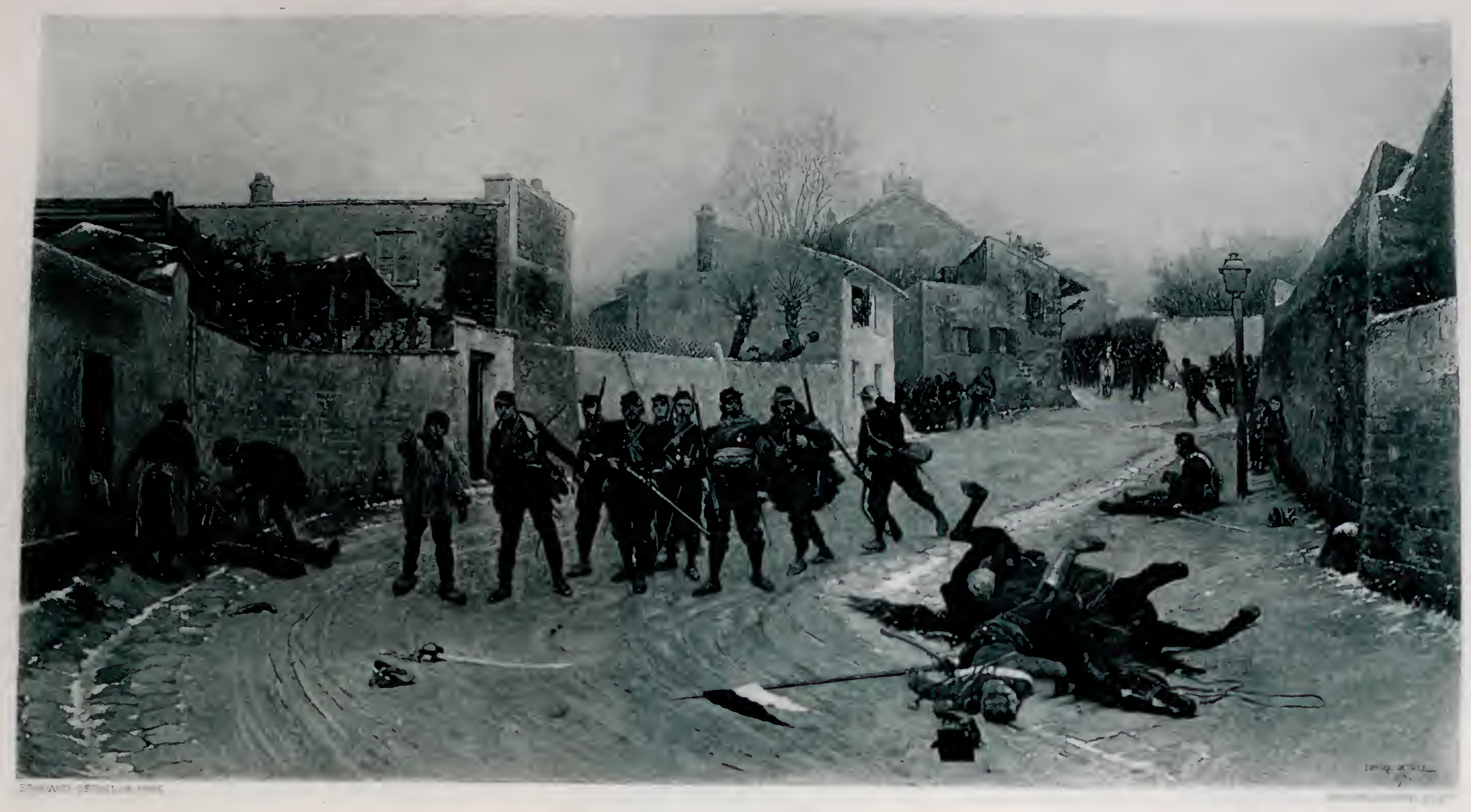




\section{RECONNOITRING.}

Goupil \& Co., Gravure.

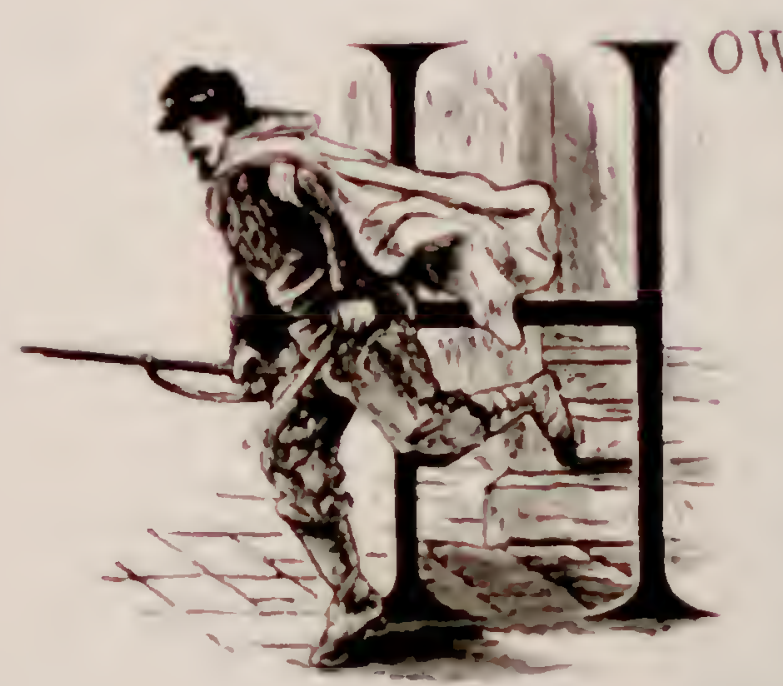

WW vivid a page from war's annals is here presented! A battalion of foot chasseurs are about to occupy a village that has just been the scene of a cavalry engagement. The main body is seen advancing at the end of the street. Entering the principal arenue from opposite sides are small detachments, who have been scouring the town to prevent surprise. The extreme van is led by the squad of men in the foreground, whose commander is receiving information from a peasant youth. From their attitudes and expressions, it is plain that they are so near the retiring enemy that a skirmish is imminent. Melanchuly proofs of the recent combat are seen in the Prussian cavalryman and his horse who toguthrre lie weltering in their blood, and in the two wounded men on either side of the road. The one on the right is probably a German, while the other, who is being succored by the inmates of the house at whose door he lies, may be a Frenchman. The villagers, who had either fled or shut themselves up in their houses, begin to show themselves again. Besides those who minister to the wounded :man, we perceive a woman cautiously peering from an upper window; and two boys, terrified, yet led on by curiosity and love of excitement, who creep slowly forward, clinging for safety to the wall. A deep and stirring sense of reality pervades every part of the picture; and as we gaze upon it, it is easy to believe that the painter is not only a close student of military life, but was himself a soldier. M. Detaille was born in 1545, and when seventeen years of age entered the studio of Meissonier. He had already made his mark as a military painter at the outbreak of the FranccPrussian war. He at once enlisted as a soldier, and took an active part in the defense of Paris, gaining at the same time invaluable experience touching his specialty in art. $\mathrm{He}$ has no superior and few equals in his chosen line. He receired medals in 1869 and 1870 ; a second-class medal in 1872; and was made Chevalier of the Legion of Honor in 1873. 




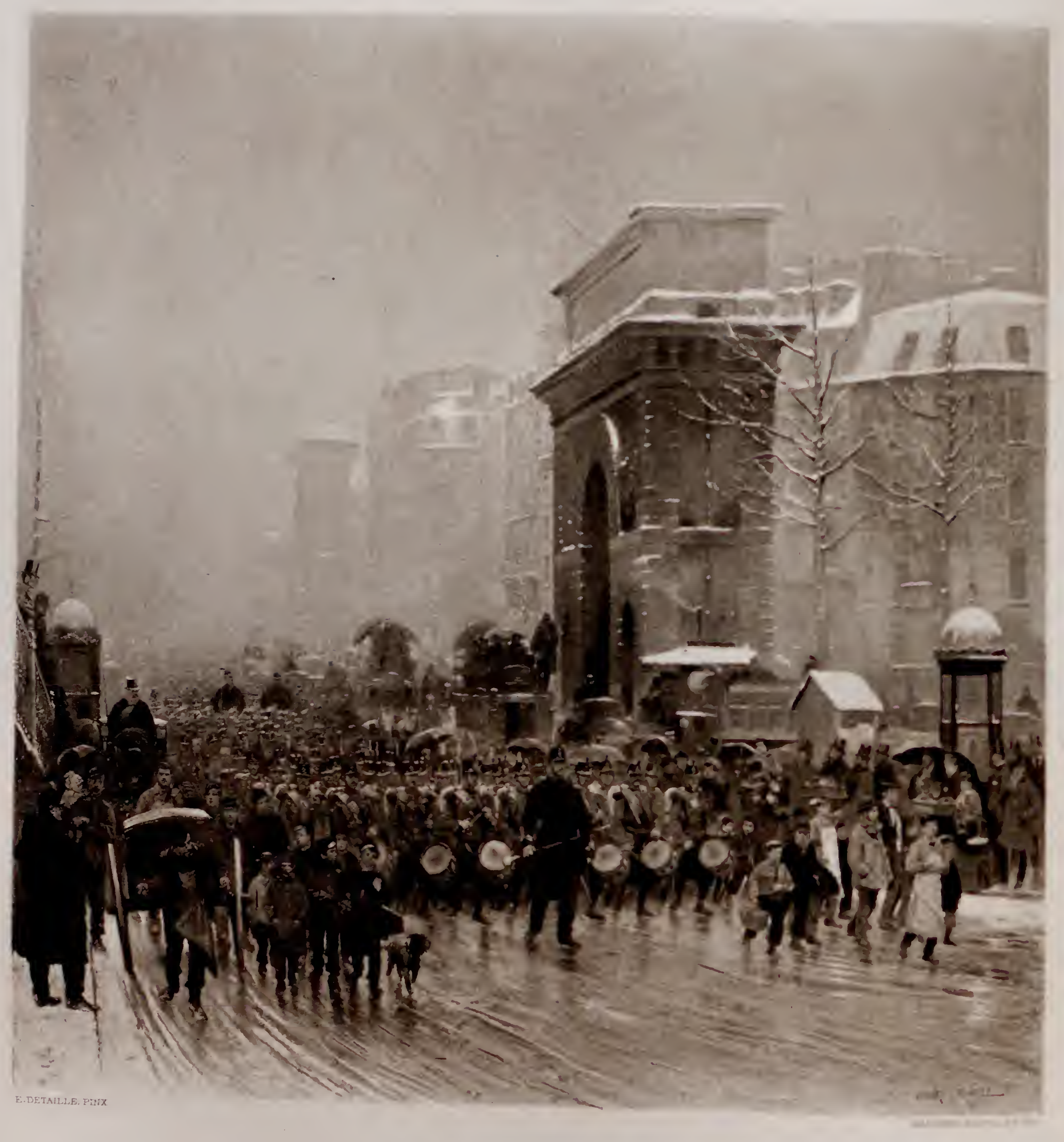




\section{The Passing Regiment.}

[FROM THE COROHAS GALLERY WASHTGTOS, D. C.]

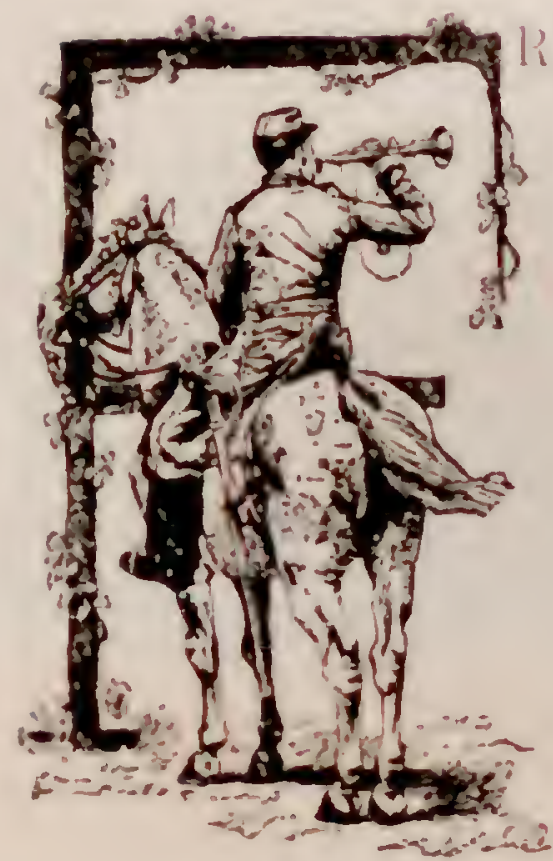

1.1CF, althomg vanquished in the war with Germany in 1870, is now a greater military power than she was in her more boastful days of the third Napoleon; in full preparation, that she shall hare no more "regiments on paper" when the next war time comes.

The visitor to Paris may witness, any day, the scene painted by Detaille, passing along the Boulevards Italian, Poissonière and St. Martin.

The exact spot chosen by the painter is opposite one of those splendid arches crevtur by "Louis the Grand," several of which are scattered about Paris, a- meinorials of the "Grand Monarch."

The arch in the picture is knomn as "The Porte St. Martin," being at the entrance to the Rue St. Martin, branching from the Boulerard St. Martin. The unat mareol of this painting is its wonderful perspective. Viewed through a hand glass, yon wn sew the mininture-finished perfect heads of the soldiers and their escorts stretch away along the bulcumds, as fur as the oye can reach. The snow-covered roof, the umbrellas and omnibusses, and the mountent ufficers in the middle of the marching infintry, aid the illusion; on the extreme right is Detaille's prepeptor. Messonicr, his hands in his cont pockets. Altogether this is one of Detaille's best pietures. mul the sem of the Comon Gallery, at Washington. 



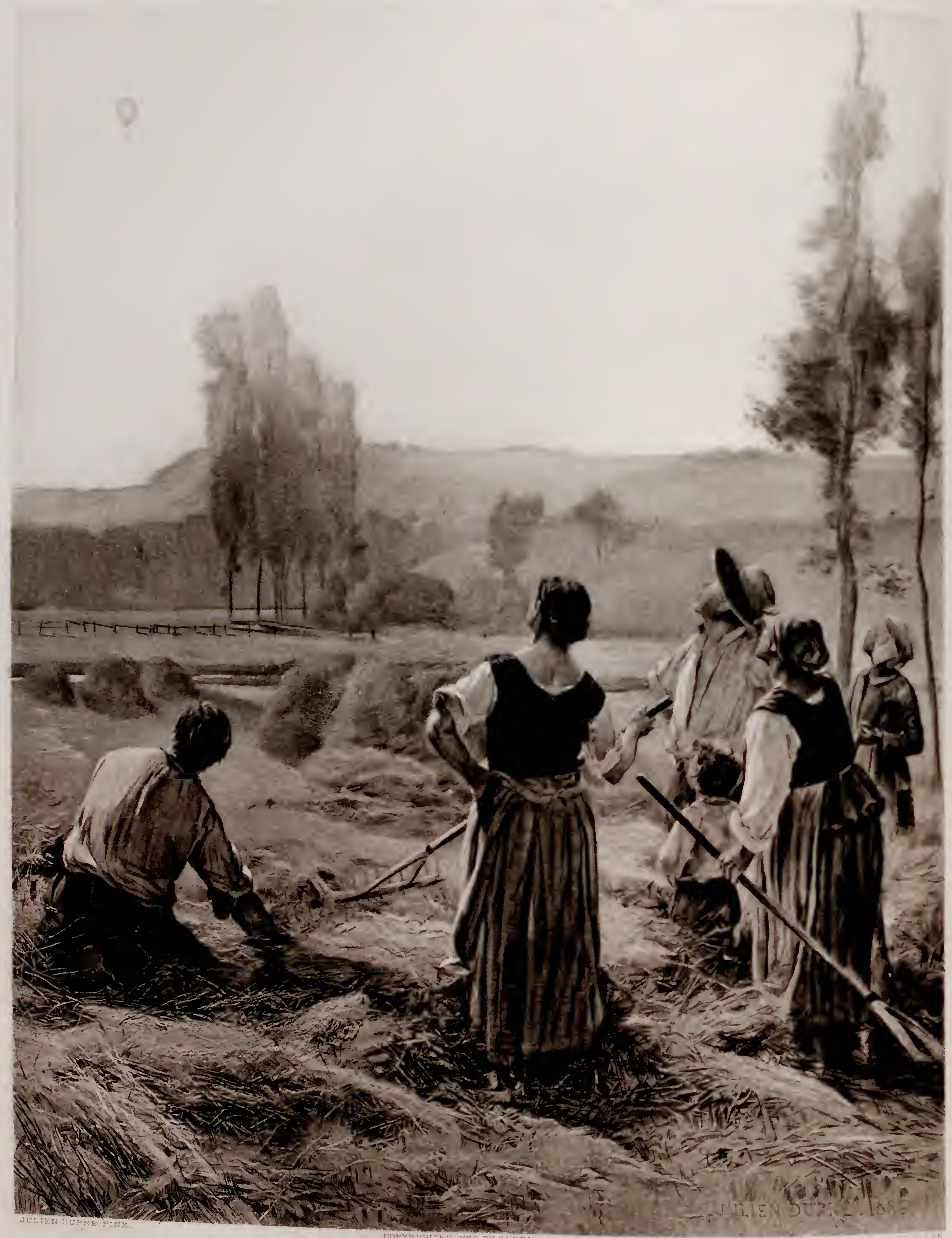




\section{'The Balloon.}

PHOTOGRAVURE FROM THE ORIGINAL PAINTING BY JULIEN DUPRE.

(FRENCH SCHOOL.)

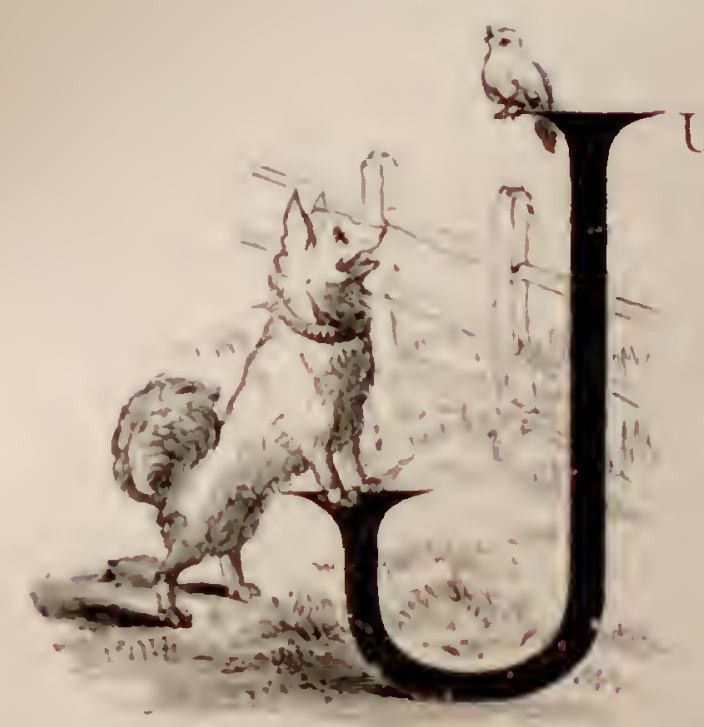

ULIEN DUPRE, son of Jules Dupre, was born at Paris about 1842 . Was a pupil of Pils, Langee and Lehnnann. He is an artist of marked talent and one of the most promising of the modern French School. In landscapes he has made lis mark as one of the leading painters of what is known as the Natural School.

The pictnre of the Balloon would appear at first sight to be a very comnnonplace subject for a painter, but in the painting, as handled by this modem artist, there are niceties of distance, perspective, coloring and costume which make it a realistic piece of work such as compels the admiration of the critic and the comntryman alikc. The ethereal appearance of the floating speck which excites the anazenent of the peasants enlists the sympatly of any one inspecting the painting, and it is one of the favorite pictures of the superb collection in the Metropolitan Musemm, New York.

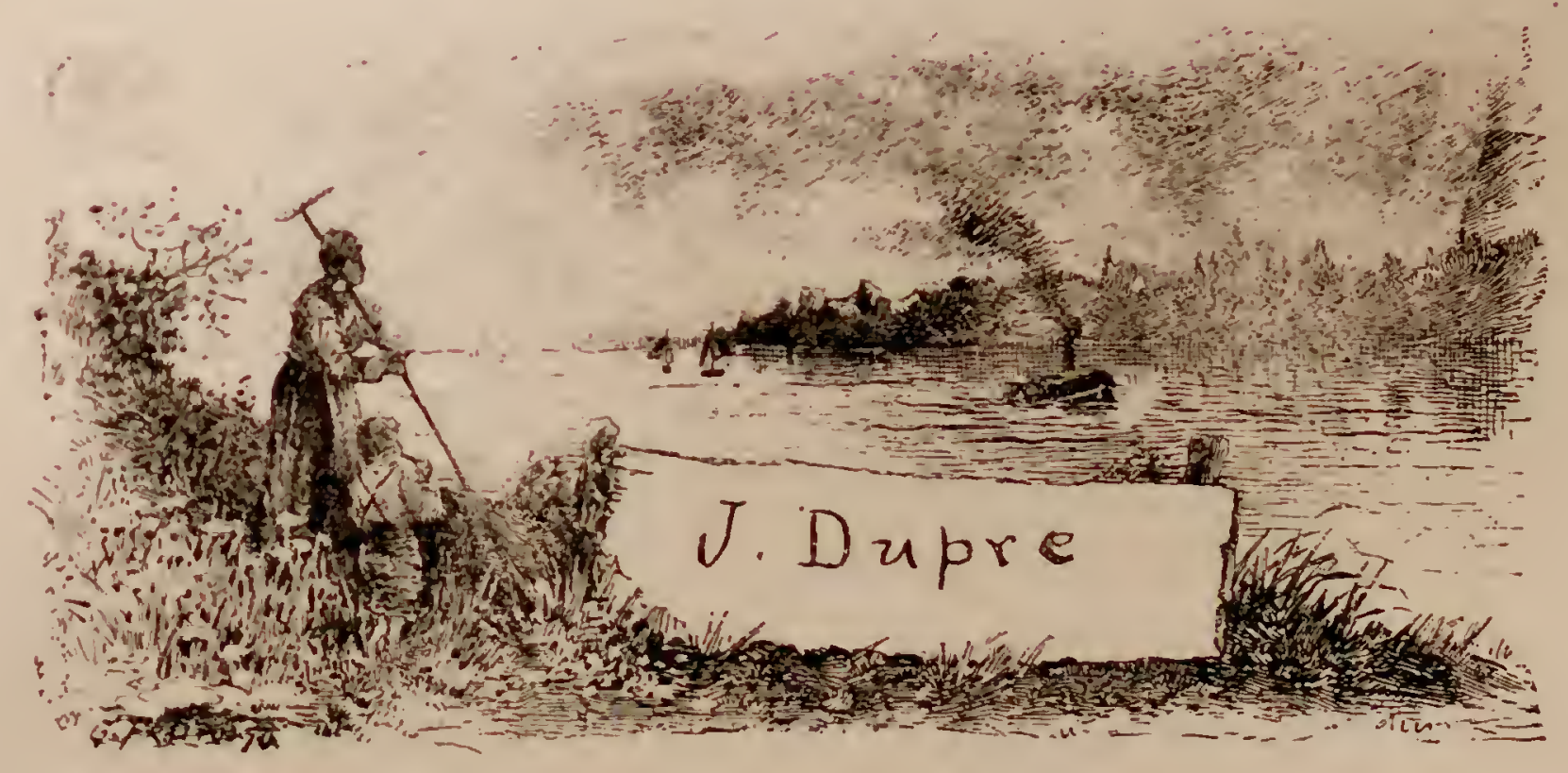





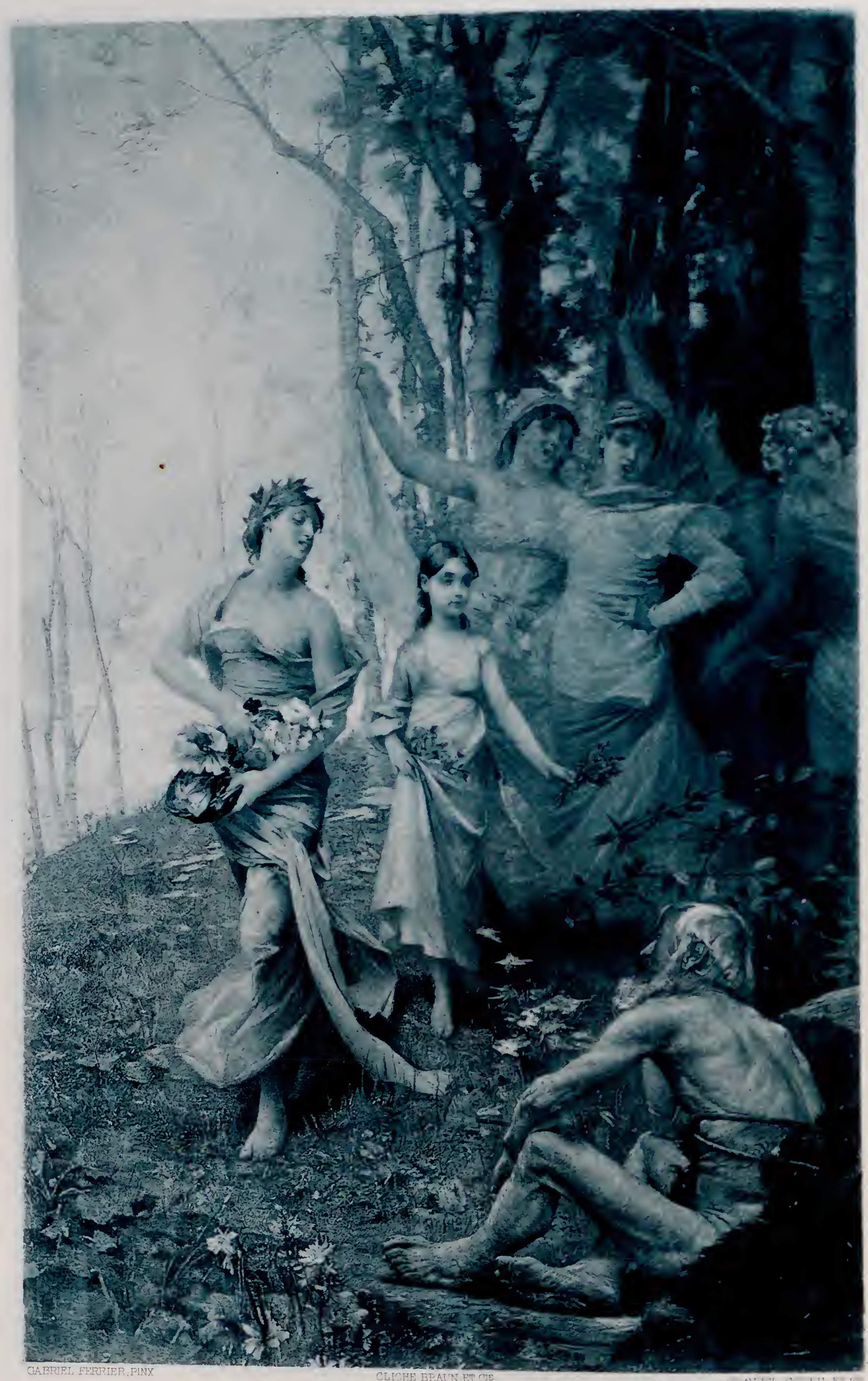

SPIRUNG 


\section{SPRING.}

Goupse \& Co., Gravure.

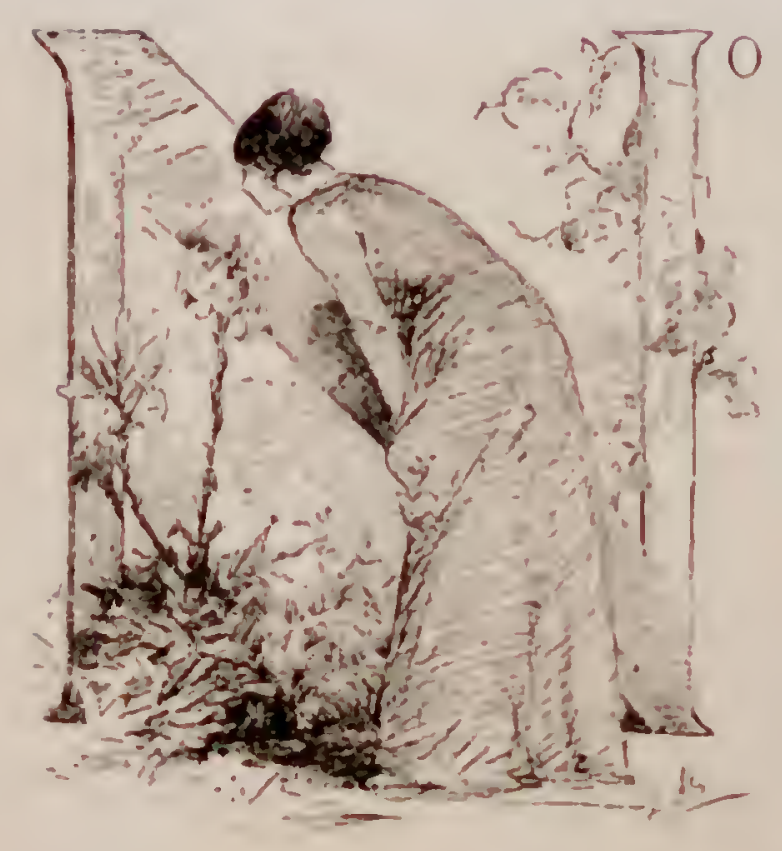

contrasts are more interesting to the loet and the painter than those of youth and age, of Spring and Winter. II. Ferrier's inspiration for the beantiful decorative panel before us, was derived from the following lines of l'ierre de Ronsard (XVIth century:

Gither, gather the joys of youth

While your years do bloom

In their carliest freshness.

Age will tarnish your beauty,

As it doth that of the flowers.

Had the painter heen English instead of French, he would probably have taken for his text Herrick's familiar lines:

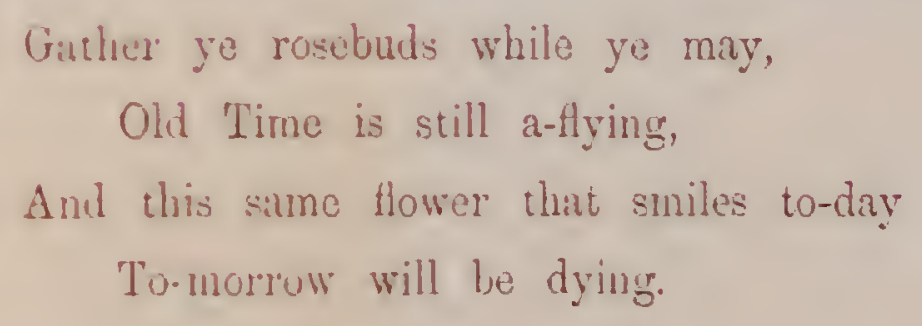

The picture reprements a troop of young girls, fair and joyous as the most beautiful month of the year, their theeks thuthed, their eyes sparkling. In coming out of the woods they pass before an (Wh man seated by the rombite, to whom, smilingly, they speak, and offer flowers. The old man, with thabby Hesk and wrinkled skin. is nule, with the exception of a goatskin wrapped about his loins. The thick forest is prolongenl on the left by some isolated trees bathed in the mist which rises from the neighlboring liake; while sentered over the soil are wild flowers, plants and briars. The contrast between the grace and beauty of youth and the decrepitude of age-types of Spring's exuberance and Winter's decay-is very impressive, and the landscape setting is truthful and charming to a rare degree.

The original painting was the subject of farorable comment at the Salon of 1881, where it was first exhibited. Mr. Ferrier, who was a pupil of ML. Pils and Hébert, won the Prize of Rome in 1872, and received a medal of the second class in 1876, and one of the first class in 1878. 




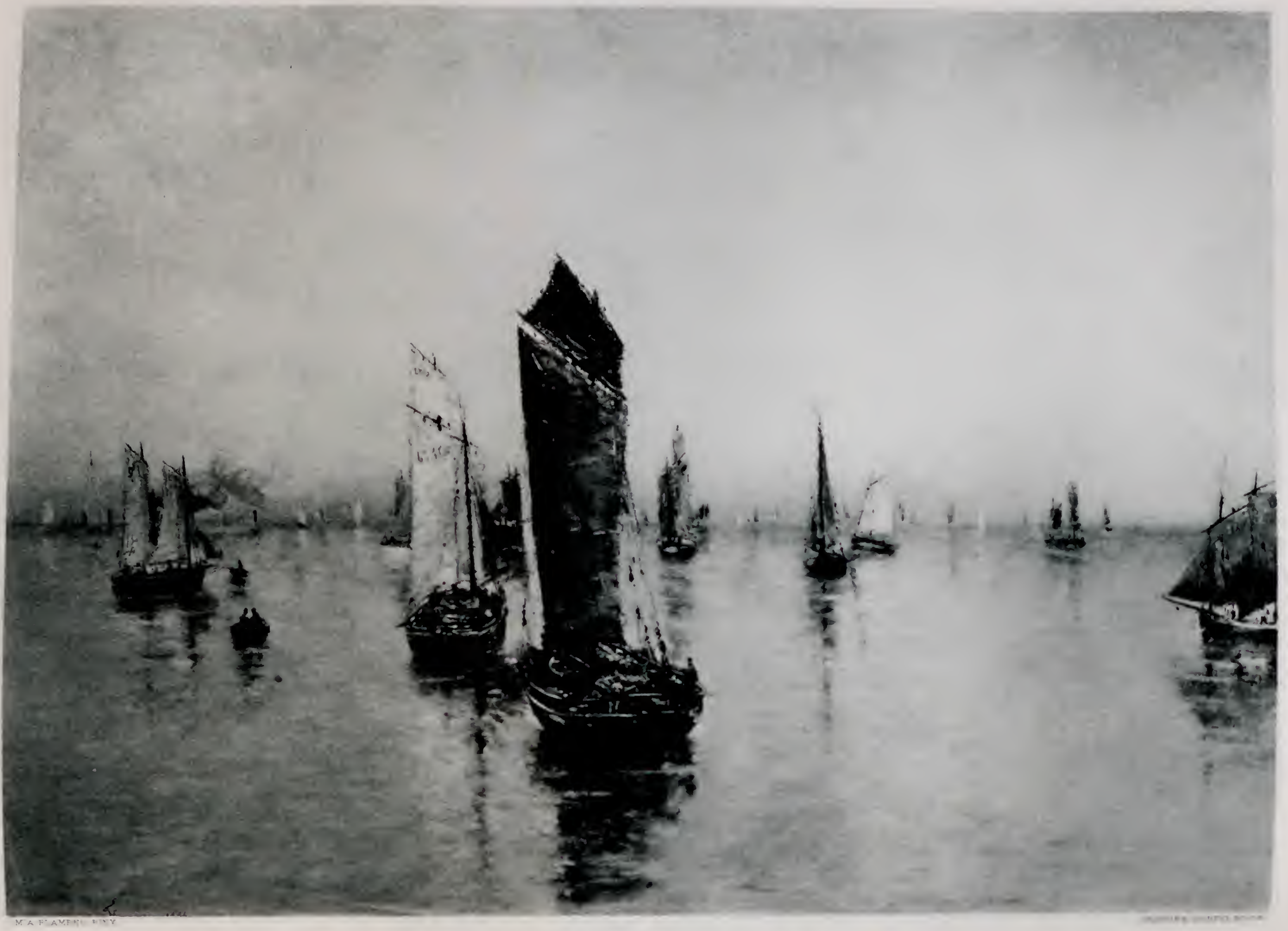




\section{Fishing Boats at Rochelle.}

Goupil \& Co., Gravure.

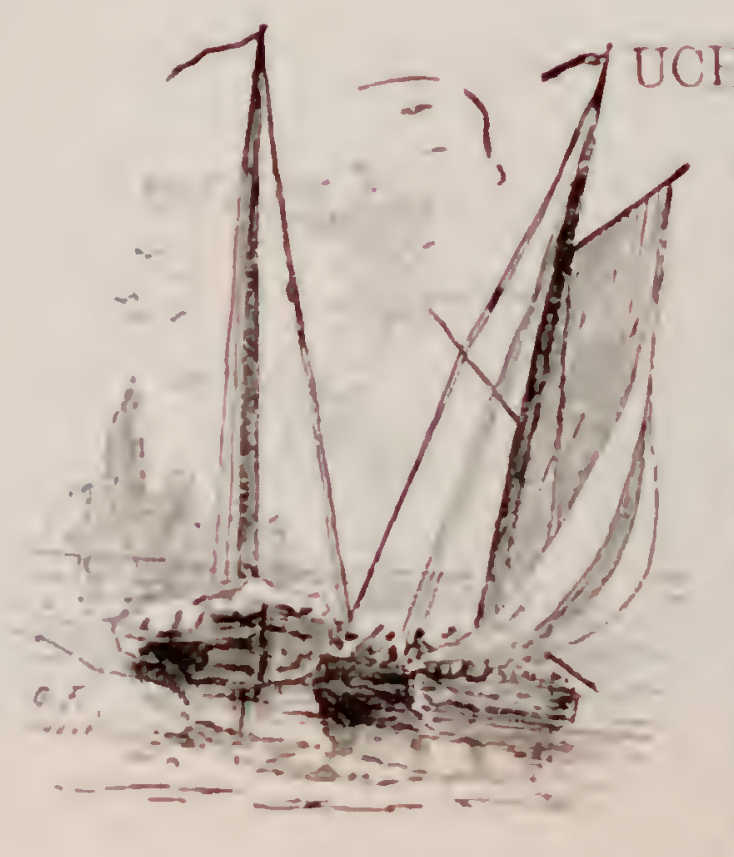

H listoric interest attaches to the locality of this pleasing picture of boats and son. Rochetle is situated on an inlet of the Bay of Biscay. It was onec a possersion of Fngland, but after being lost and won several fimes it revertenl permanently to its original and proper owner, France. In 1537 it fell into the lunds of the IJuguenots, to whom it remained a tower of strength till 1628, when it was wrested from them by Louis XlII, after a siege of fourteen months. The old fortifications were then destroyed, and new and stronger works erected by Cardinal Pichelieu. Anong the various industries of the city ship-building holds a prominent flace, especially in connection with the Newfoundland fish-

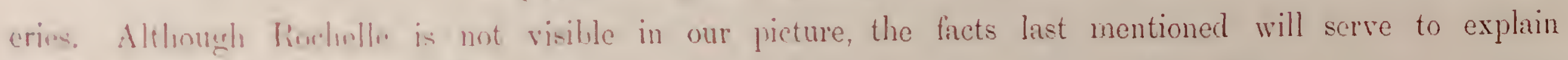
the presence of wis larre a flect of sailing boats dotting the capacious inlet. The scene is so simple ami sn matural that it is may to lose sight of the thorough study and mastery of technic necessary to the production of such at picture. The truth of perspective and the slightly raporous atmosphere, sutfised with light, aro especially notable. The little ships swim here and there, buoyant as waterfowl, their sails somatimes reflecting the sunlight and sometimes presenting masses of cool shadow; while the clear waters of the Bay mirror the luminous over-arching sky.

The painting was exhibited at the Salon of 18S4. M. Flameng, who was born at Metz, has profited by the tuition of such masters as E. Vernier, Dubufe, Mazepolle. F. Delaunay and Puvis de Charannes. He was awarded a medal of the third class at the Salon of 1831. 



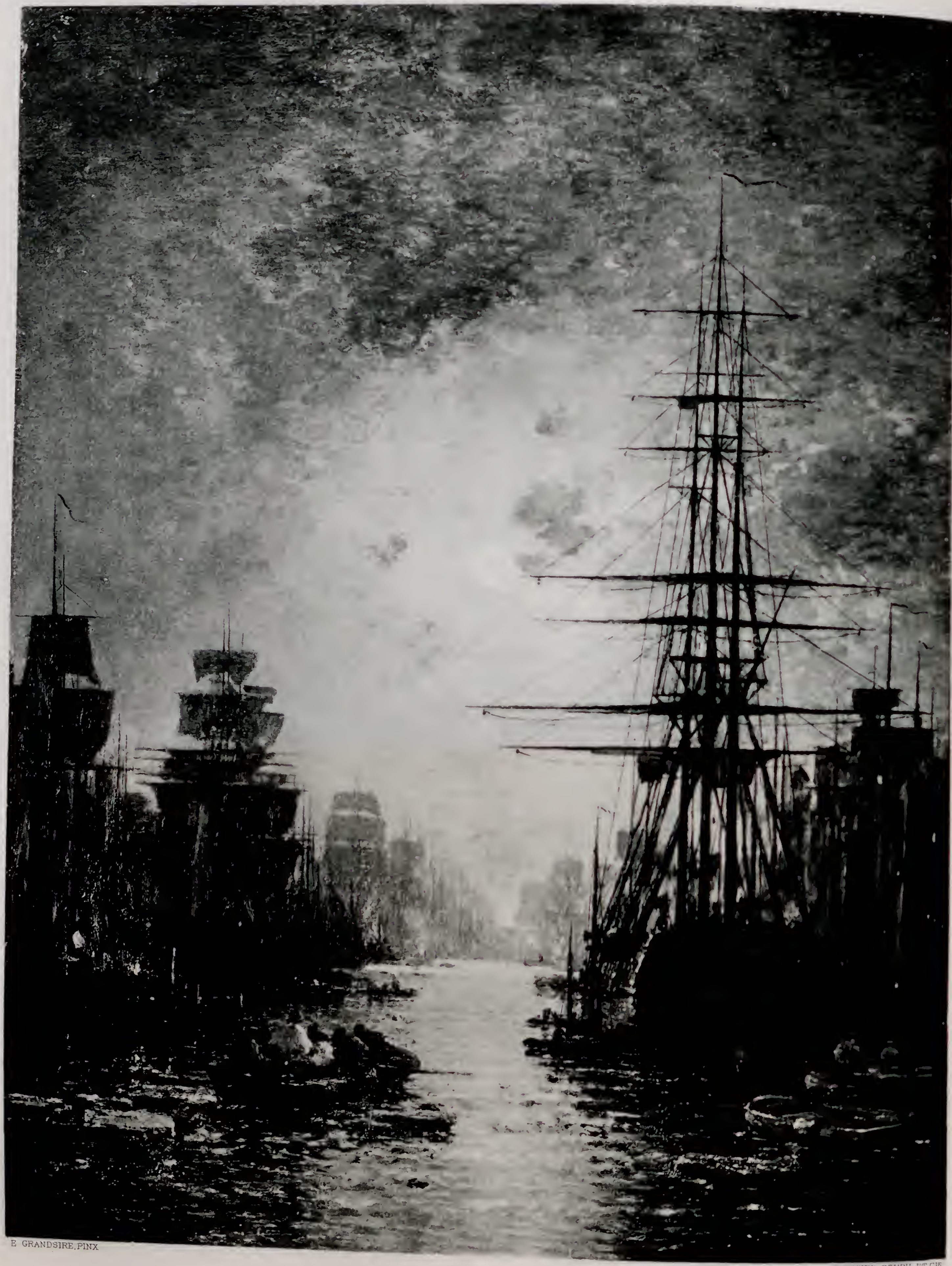




\section{Moonlight Effect in the Kattendyk, Antwerp.}

Eugene Grandsire, Pinx.

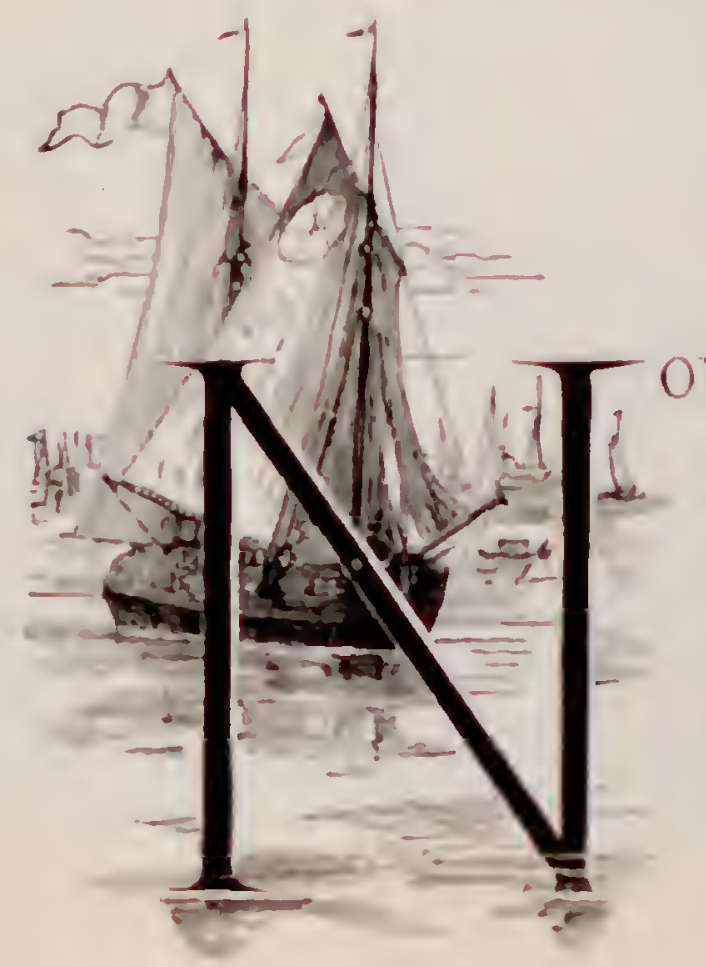

Goupil \& Co., Gravure.

the is again Imoferous and rich, and holds a respectable place among the world's busy marts.

The scene of our picture is one of her great docks, capable of accommodating a thousand vessels. The lines of shipping, whose tall spectral forms stretch away in vague perspective on either hand, are divided by a broad path of light cast upon the quiet night-scene by a full moon. The activity and stir of day have given place to decp silence, disturbed only by an occasional isolated voice or the plash of an oar. The subtle attractions of the subject, - light and mystery, - have been happily realized by the painter.

M. Grandsire, a native of Orleans, studied under J. Noel and J. Dupré. Though most frequently treating landscape themes, lis excellence in water views is sufficiently attested by the present work, which was exhibited at the Salon of 188t. He is a Chevalier of the Legion of Honor. 




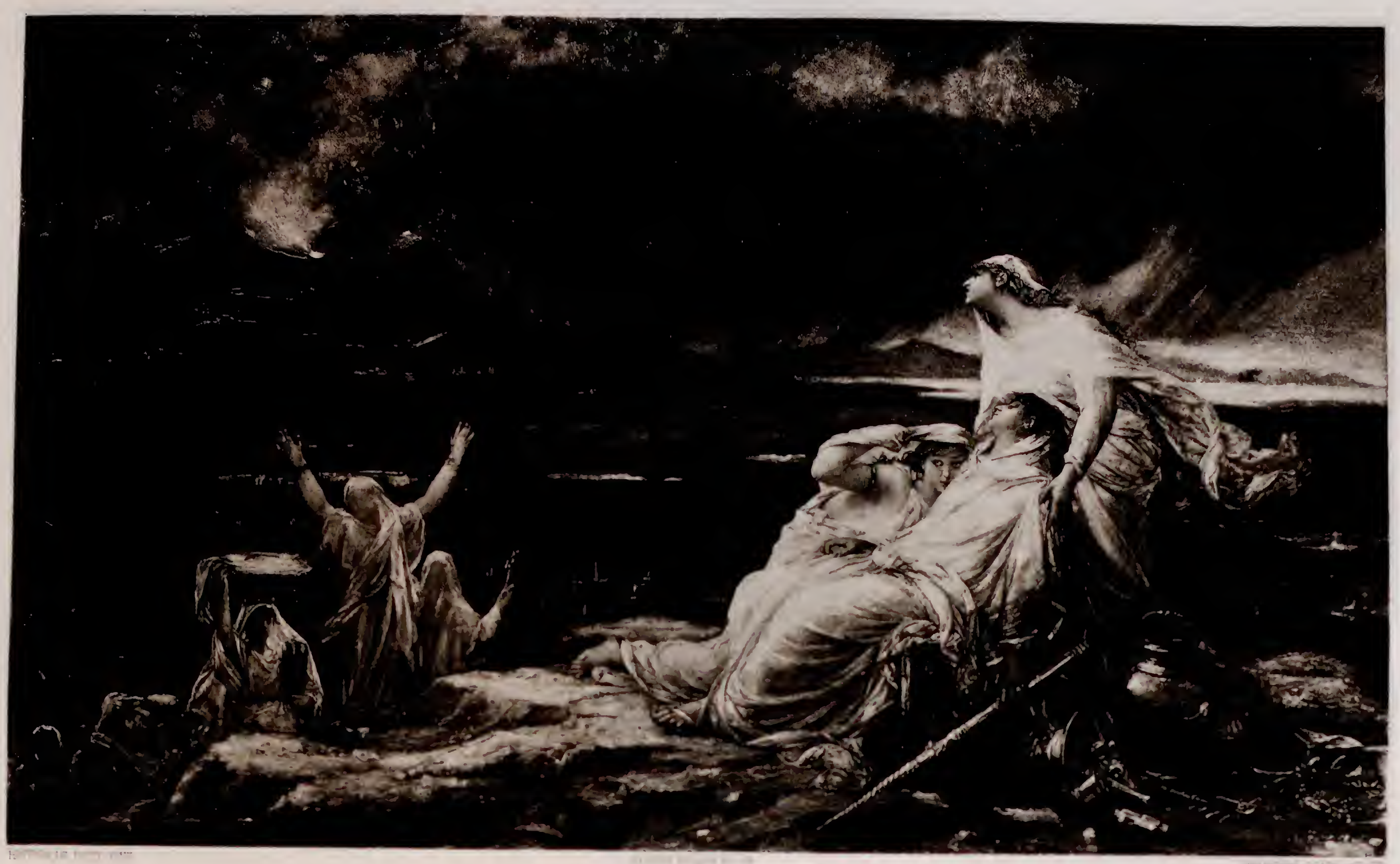




\section{Herculaneum.}

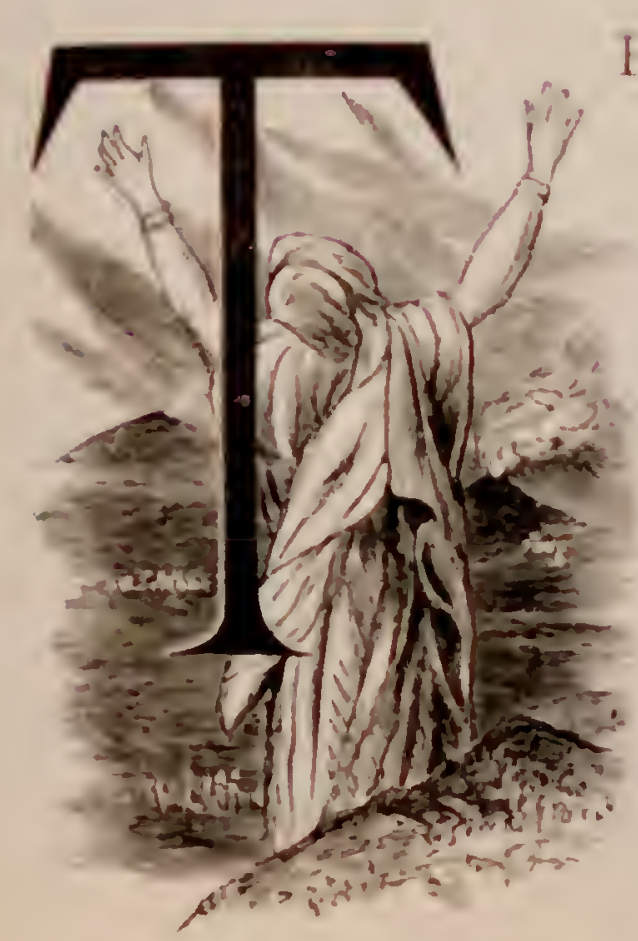

HIS canvas vividly impresses us with the terrors of that awful eruption of Mt. Vesurius, which, on the 9 th of August, in the year A. D. 79, overwhelined three Hourishing towns. Great volumes of smoke and ashes were shot up to an immense luight, and. spreading out, liung over the earth like a heavy pall, being the more terrible from the tongues of fire that mingled with the aseending smoke, and cast a lurid glare upon the scene of woe. Meanwhile the land and sea were alike convulsed with violent eartliquake shocks. The imagination can but meagrely picture the panic, confusion, and distress attending the sudden flight of the inhabitants of the doomed cities. The ashes blown over Pompeii, buried that city so deeply as to hide its very site; while Herculaneum was engulfed by the molten lava.

The artist has represented the flight, from the latter city, of a company of vestal virgins. They have brought away with pious care, the sacred ressels and symbols committed to their custody; and lanving at Jomgth niade their toilsome way to a place of comparative security, they pause to rest, and to take a last drepairing view of their perishing city. The lines of light that appear on the dark mountain sibe, mark the strean of liquil frre that is coursing down to the plain below. where it may be scen, rolling like oecan billows towards the fair city that it will soon blot from existence. The picture is imbued with a profound appreciation of the great tragedy, which it brings before us witl the simple power of truth, free from all extravagance or exaggeration. It was exhibited at the Salon of $18 S 1$.

M. Hector Le Roux received Salon medals of the third class in 1863 and 1864: one of the second class in 187t; and a medal of the third class at the Universal Exposition of 1878. He was made Chevalier of the Lecgion of Honor in 1877. 



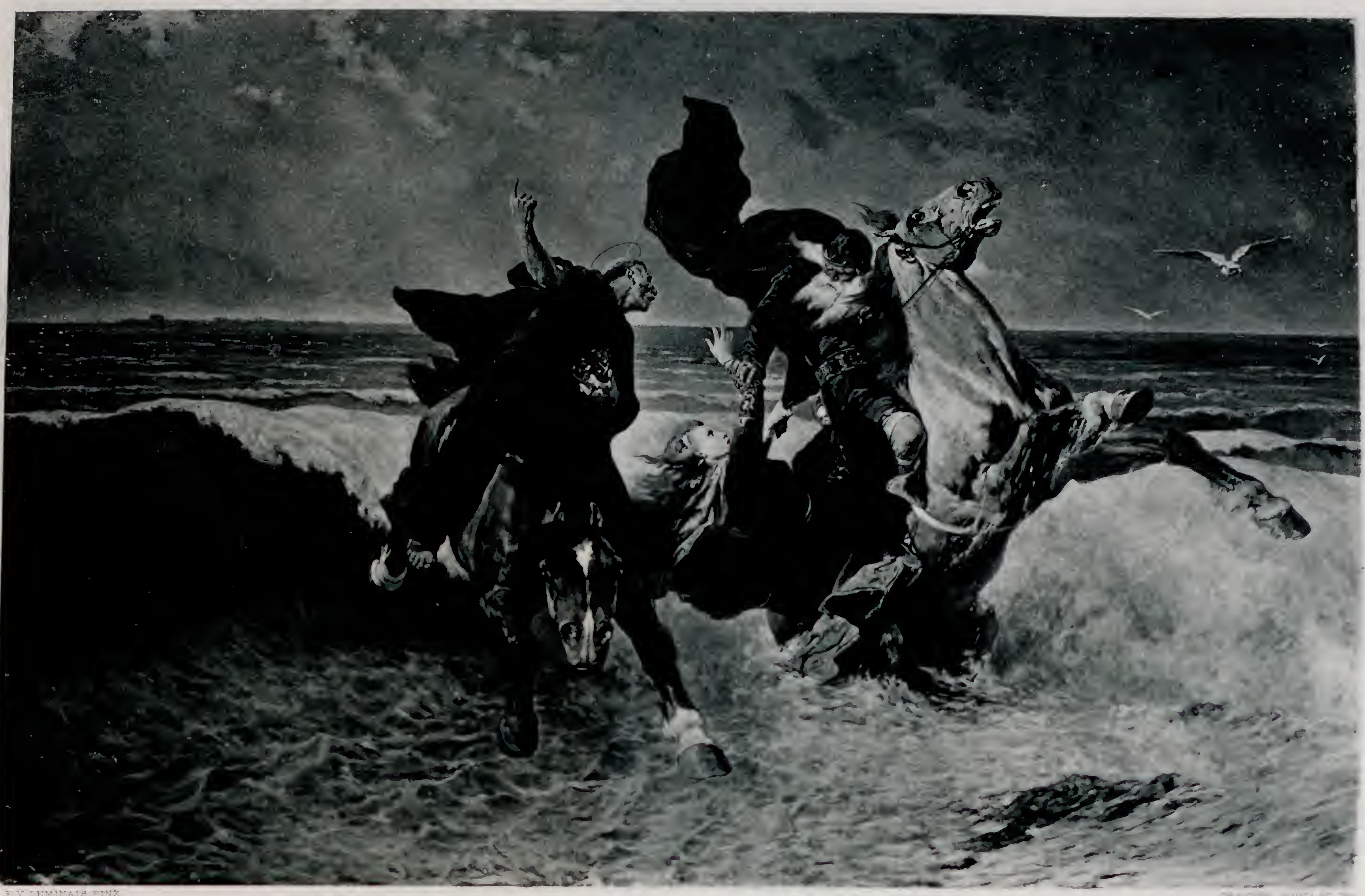




\section{The Flight of Gradlon: A Breton Legend.}

Evariste-Vital Luminais, Pinx.

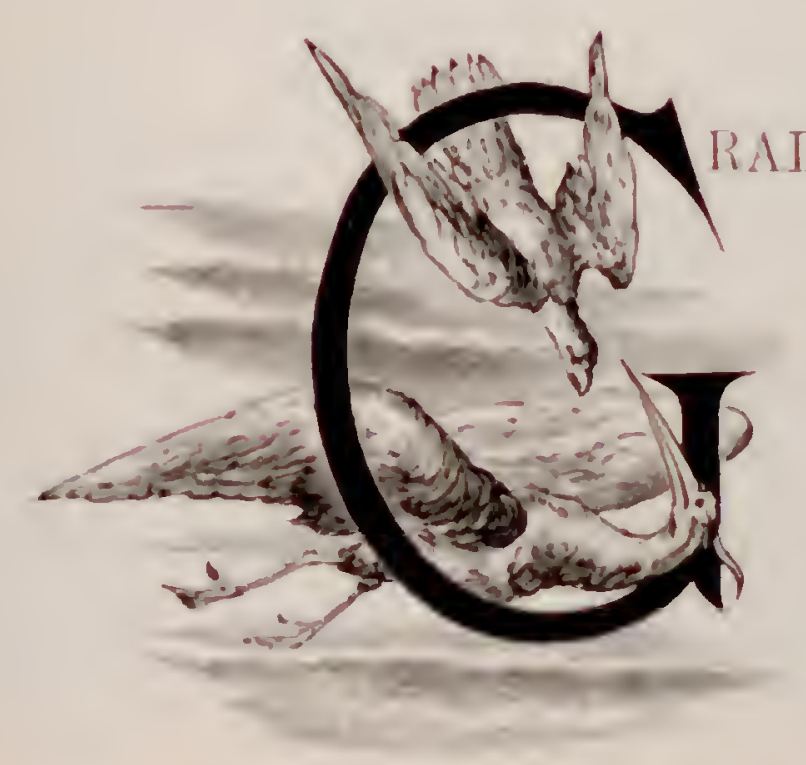

RADLON was an ancient king in Brittany, his capital, d'Is, being situated on what is now known as the Bay of Douarnenez, in the province of Finisterre. According to the legend, the city was once surprised and overwhelined by a sudden rising of the Ocean. There was time alone for the swiftest flight. Mounting his horse, with his daughter behind him, and accompanied by Saint Gwenolé, they urged their desperate way through the surging waters. At a critical moment the monk crierl: "'Disembarrass thyself of the demon who shares thy saddle, for it is she who by her diworders has drawn down the anger of Heaven.' The king, recognizing in these words the ruice of God, hagd the courage to abandon his daughter, and was enableul to reach safe groum at a place now called Douarnenez."

The tragical incident is simply and powerfully exhibited. The consternation and mute appeal of the sacrificed diughter; the firce expression of the father nerving himself to the umnatural act, and the rude fanaticiom of the saint, are alike impressively truthful; and the scene finds a fitting retief against the lowering sky and omnivorous flood, with the elerations of the doomed city faintly descried in the distance.

M. Luminais, eminent in the high role of historic painting, was born at Nantes, about 1818 , and was a pupil of Cogniet. As a painter, he "places at the service of bold, conscientious drawing, the prestige of large execution and brilliant color." He has been honored with several medals and with the Cross of the Legion of Honor. 



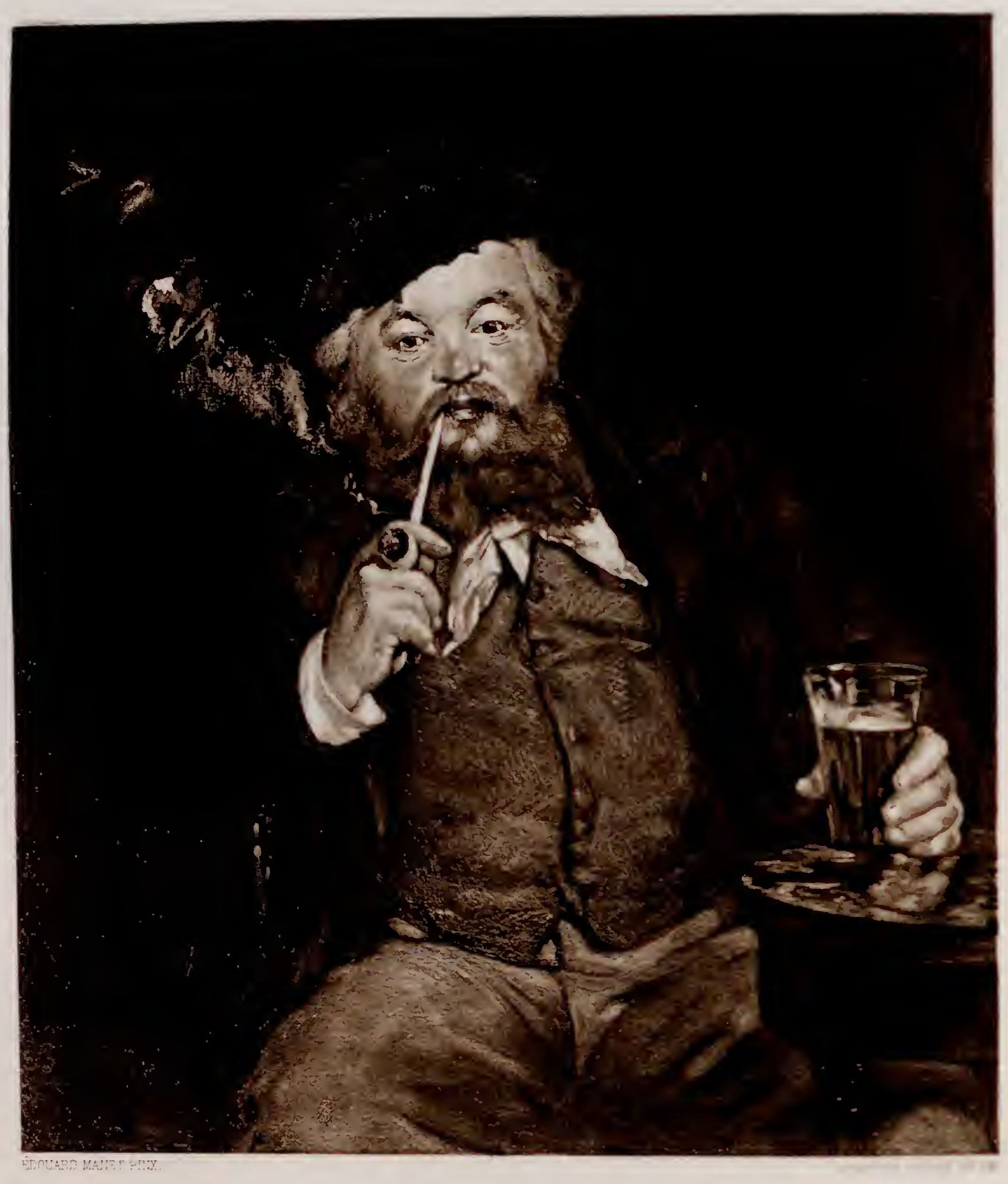

90010 BOCK BY: 


\section{GOOD BOCK BEER.}

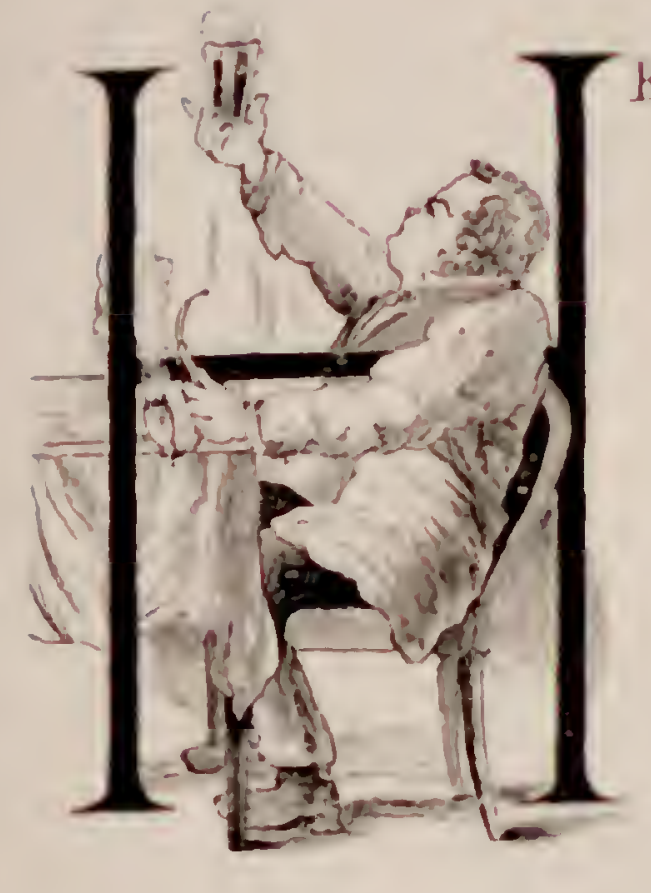

ERE is a thorough-groing materialist, - a man who doesn't bother his head with motaphysical speculations, and who has no aspirations that the present state of existnce cannot fully satisfy. Look at him. Why, not eren a cat purring on a suft rug before a glowing fire-place, could present a better picture of perfice contentment than this lover of boc beer and tobacco. Indeed, so deep and all-pervading is his present felicity that there is almost a touch of prathes in it. What is he thinking of? Well, probably he is not thinking at all, but only revelling in the delicious languor of senses steeped in saticty. Shakipeare makes Cirsar say:

"Let me have inen about me that are fat;

Sleek-headed men, and such as sleep o' nights;

Fond Cassius has a lean and hungry look;

He thinks too much: such men are dangerous."

By this token our hiver of Bock is not a dangerous member of the community-unless. indeed, in a thime of scarcity. when lis presenen might well occasion grave concern.

M. Munn lan bern callew the "high priest of ugliness" by some of the critics, and not without cause, as certain of his pictures have exhibited a repulsireness that was almost gratuitous; but other of his work are only objpctionable on the grounds of ultra "impressionism " and "realism." He was born in 15:3:3 and finishal his studies under Couture. His first exhibits were in the Salon of the Pufured in 1563.3. He exhibited in the Salons of the two following years. but in 1366 his works were refused by the Jury. Sine then he has exhibited regularly, although his Nana (1STT) was rejected on the ground of indelicalcy. Mr. James Jackion Jarves says: "Nanet is one of the eccentricities of modern art, as Whister is another, but better. variety." Another writer expresses the opinion that Manet's Nance "shows his appreciation of grace and elegance" and that his portrait of Faure in "Hamlet" (1877), proves him "the strung master of a noble strle." The Good Bock Beer was exhibited in 1873 and was a popular success. In 1831 M. Manet was honored with a medal of the second class. 




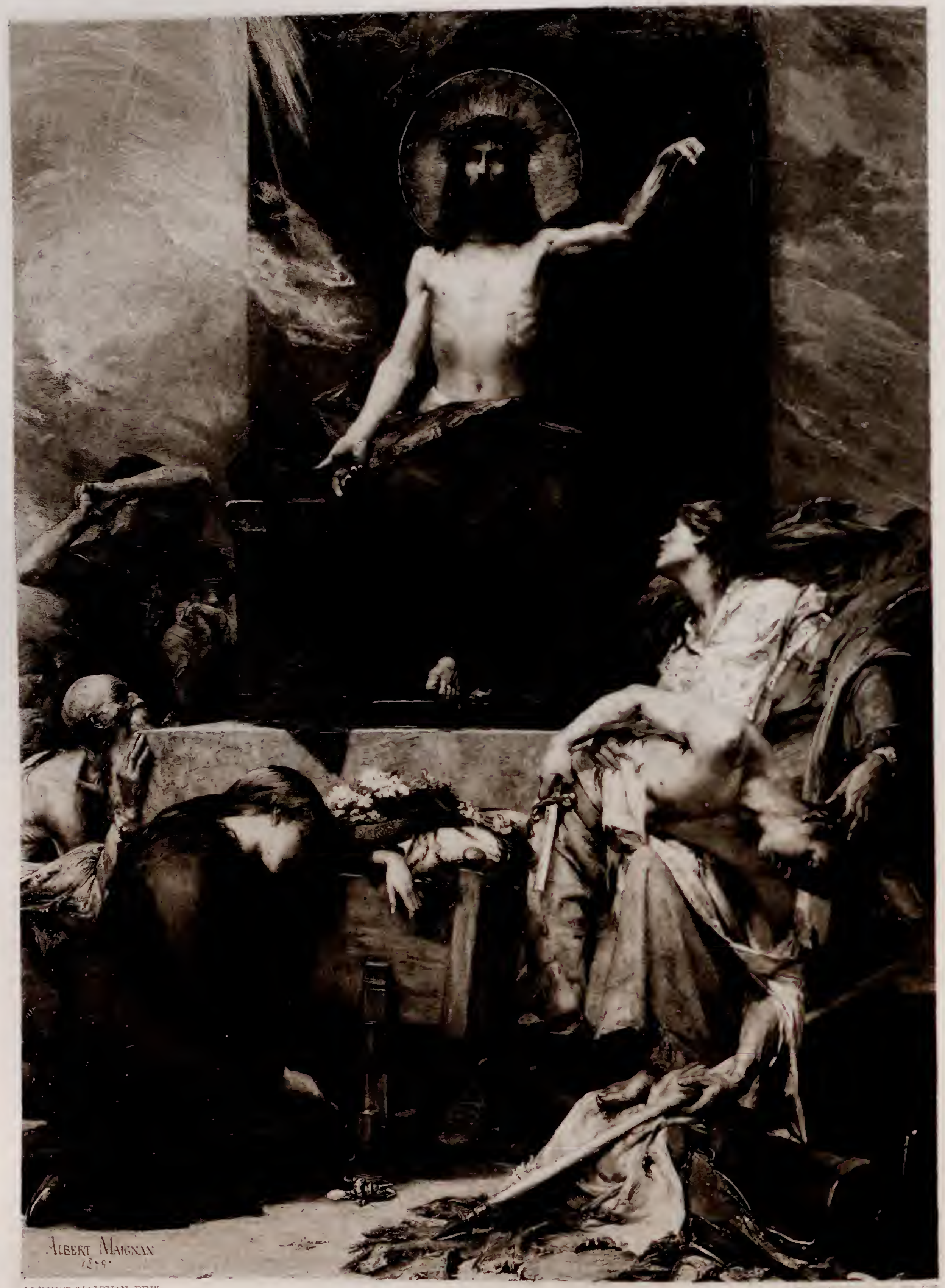




\section{Christ's Invitation to the Afflicted.}

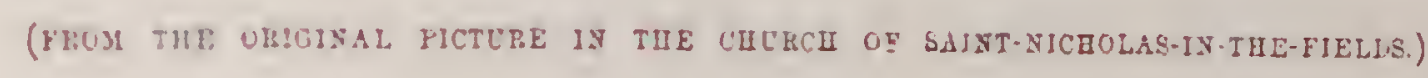

Goupil \& Co., Graure.

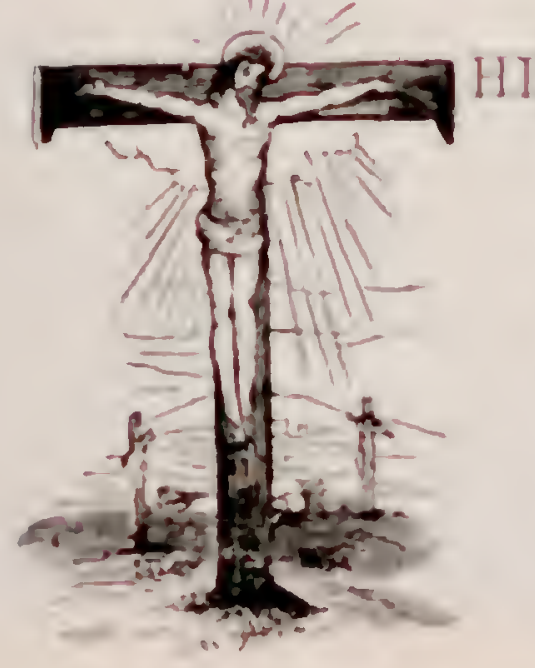

HIS truly great picture almost beggars description. It was inspired by that sorrow-taden ery of "the Weeping Prophet," "Behold and see, if there be any sorrow like unto my sorrow!" When the human heart is wrung with anguish, it recks comfort from those who have known aftliction, for from such alone can true sympathy proceed. But after all, how unsatisfying is the best earthly consolation! "Every heart knows its own bitterness," - no two experimenes are alike; and hence the impossibility of that perfect appreciation that is escontial to complete sympathy. Thus it is that, in its dire distress, the soul curns heavenwaril. Une alone has tasted every sorrow; and that one, the Sariour Christ, is nut only "toucherl with the feeling of our intirnity," but has power to minister relief. "Come unto me all ge that labor and ar heavy laden, and I will give you rest." With what sublime pathos has the paintor, in this womlerful altar-piece, declared this blessed evangel! Here is the grief-stricken wif briating har huband slain in battle; here the young mother bowed by the coffin of her firstburn infint: here Awropit ane nud poverty; and back of these a multitude of the tempted, the outcast, the forsaken, -and all alike come for succor and solace to the "Man of sorrows, and acquainted with grief." M. Maignan has portrayed the Redeener in the spirit of a ruder age, when art was the expression of religinus feeling. He has thus placed it in strong contrast with other portions of the picture, in which inastery in the drawing of the human form, a tender feeling for color, and a superb chinoscuro, are simnally displayed. The picture was one of the most distinguished contributions to the Salon of 1579. It now appropriately decurates the altar of the Church of Saint-Nicholas-in-the-Fields. 



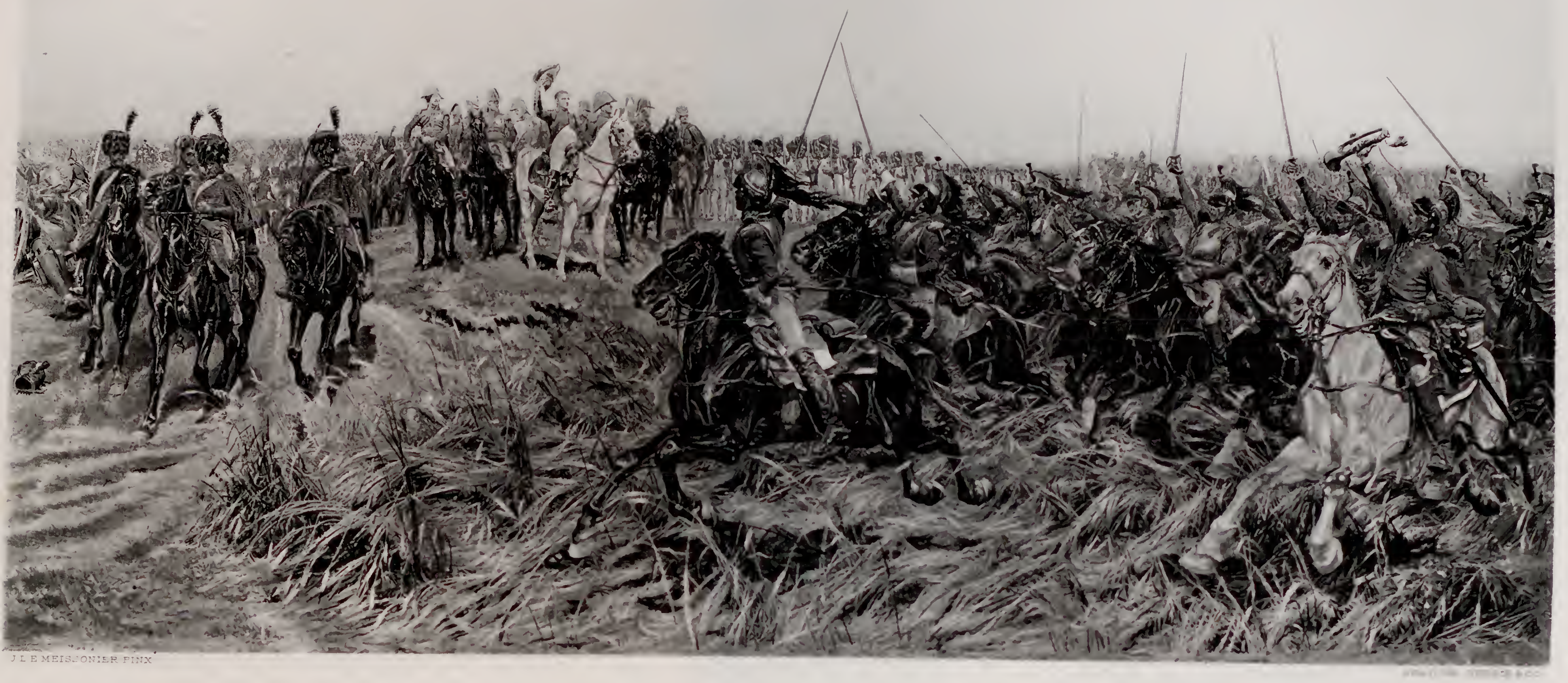




\section{7.}

PHOTOGRAVURE FROM THE ORIGINAL PAINTING BY J, L. 5. MEISSONIER.

(FRENCH SCHOOL.)

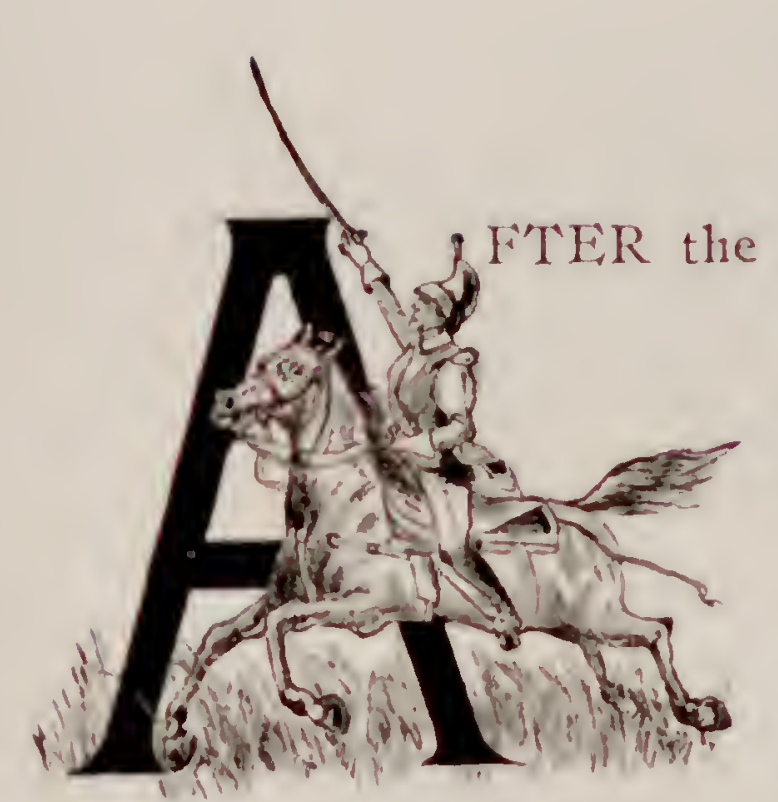

said: "A painter has never, perhaps, represented a composition of a general and his army in which the feeling seems so homogeneous; in which the leader reposes in the sympathy of his troops so like a soul in a body."

The Emperor is surrounded by his marshals, Bessieres, Duroc and Berthier, while behind, on the left, Nansouty is about to wheel into line. The cry arises, "Long live the Emperor!" and the colonel of one of the regiments gives greater effect to his cry by rising in his stirrup to his full height as he shouts.

The review occurred near to Friedland, and the painter originally intended to have named his picture after that place, but as it represents a review, and not a battle, he named it after the period, I807.

Historically, a writer in L'Art points ont that the troops were, really, physically worn out by their long ten days' campaign against the Russians without truce or rest, having killed, or wounded, or captured in that time 60,000 of the enemy; but, tired out though they were, they rose to the occasion to salute their victorious general.

Meissonier labored fifteen years on this picture and Mr. Stewart is said to have paid him $\$ 60,000$ for it. It sold at the Stewart sale in March, $188_{7}$, for $\$ 66,000$, being purchased by Judge Hilton, and has since been presented by hin1 to the Metropolitan Museum, New York. This painting is Meissonier's Masterpiece.

M. Meissonier was born at Lyons in $\mathrm{I}_{\mathrm{I}} 3$, and is, perhaps, the most popular artist of his time.

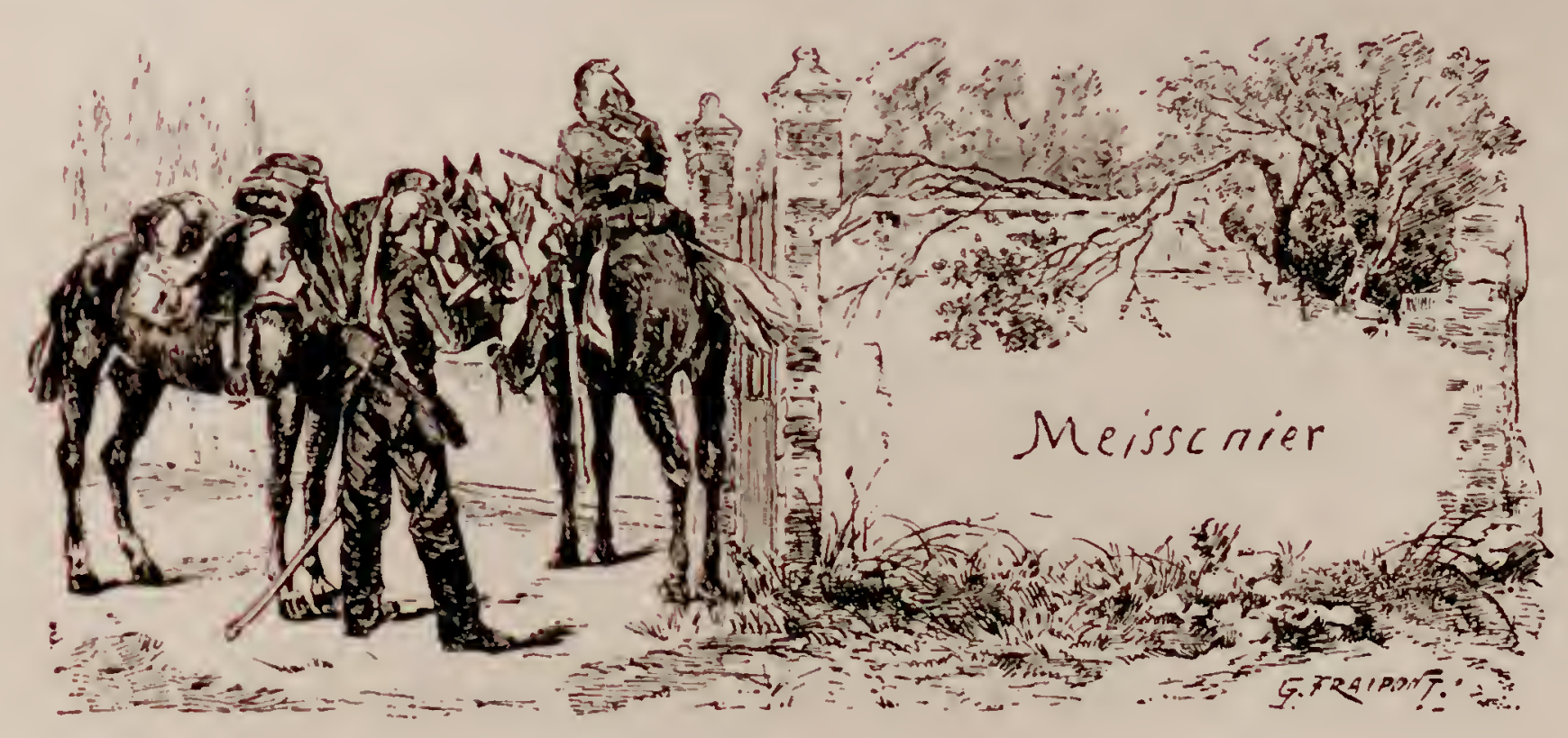






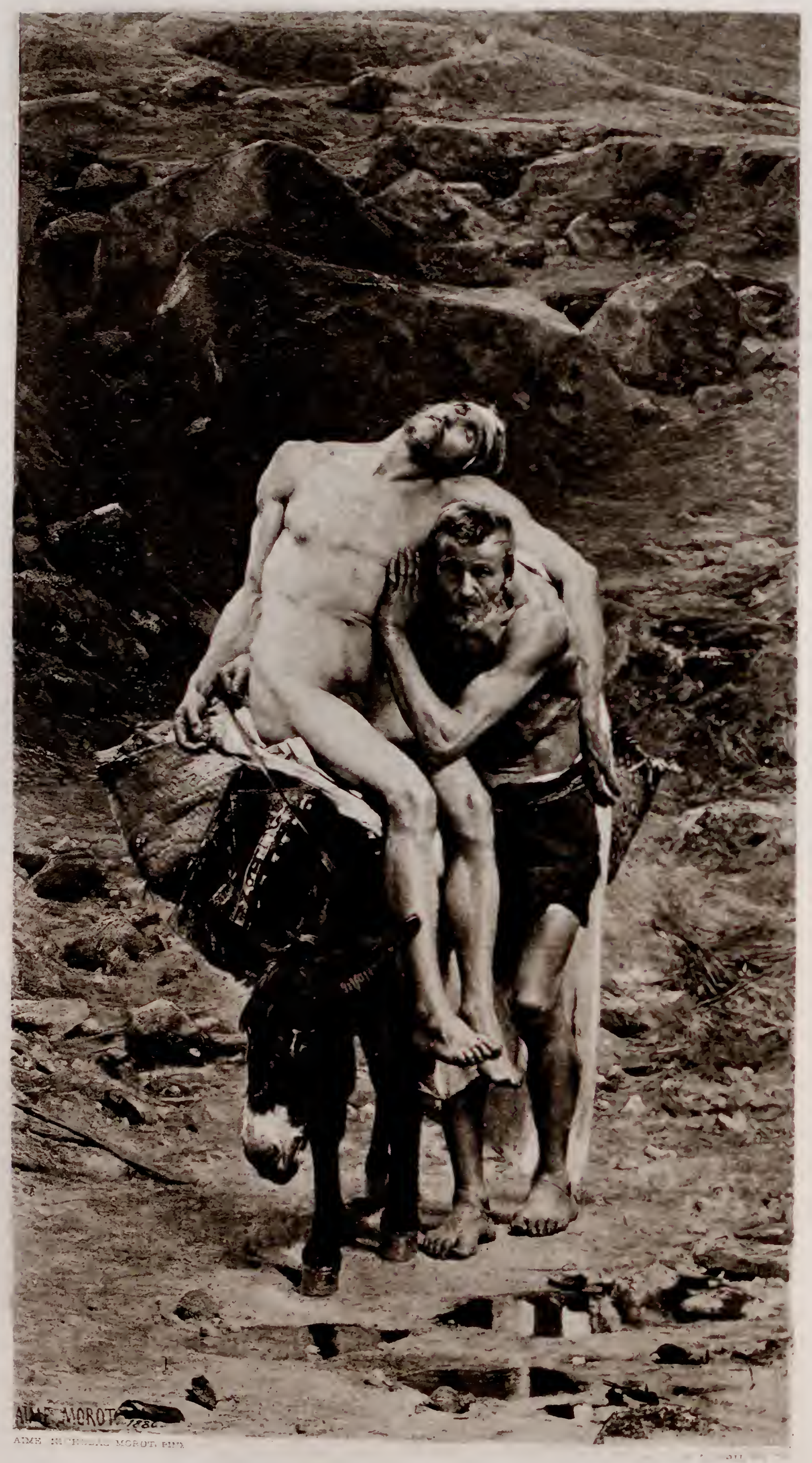




\section{The Good Samaritan.}

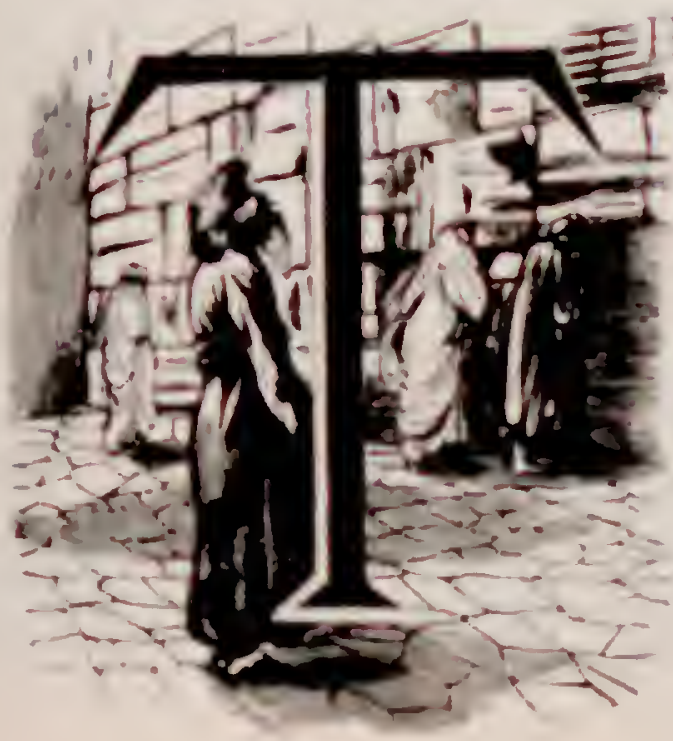

F: sury of the Gond Samaritan preserts a rerfect type of charity. The kimlly deen wins disinterested, practical, mostentatious. The menory of it lingers like a swoet perfume; and though even the name of the hero is nnknown. a mow and better name has been conferred upon him, - that of "The Good Man of Samaria," and wherever this is pronounced it quickpus kimily impulses in all hearts sare those

"hreasts of stone that cannot melt

In soft aloption of another's sorrow."

M. Momt he trentind lois subject in a realistic manner. The road from Jerusalem to Jericho has luen from time inmmorial infinteul with robbers, its rucky, precipitous character-well shown in the picture - nflimling convenient hirling-places for these outlaws.

As in the Trmptation of S\%. Anthony, by the same artist, we have here a consummate example of figurepainting. The exhan-tion expresced in the relaxed neck and drooping limbs of the wounded unm is preffect. Note also the discrimination in quality of flesh and the texture and color of skins. The work is chatacterized by a noble simplicity, well according with the serious and elevated subject. M. Morot, who was a puril of Cabanel, won the Prize of Rome in 1873, and obtained the Medal of Honour, by this picture, in the Siton of 1580. 


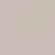





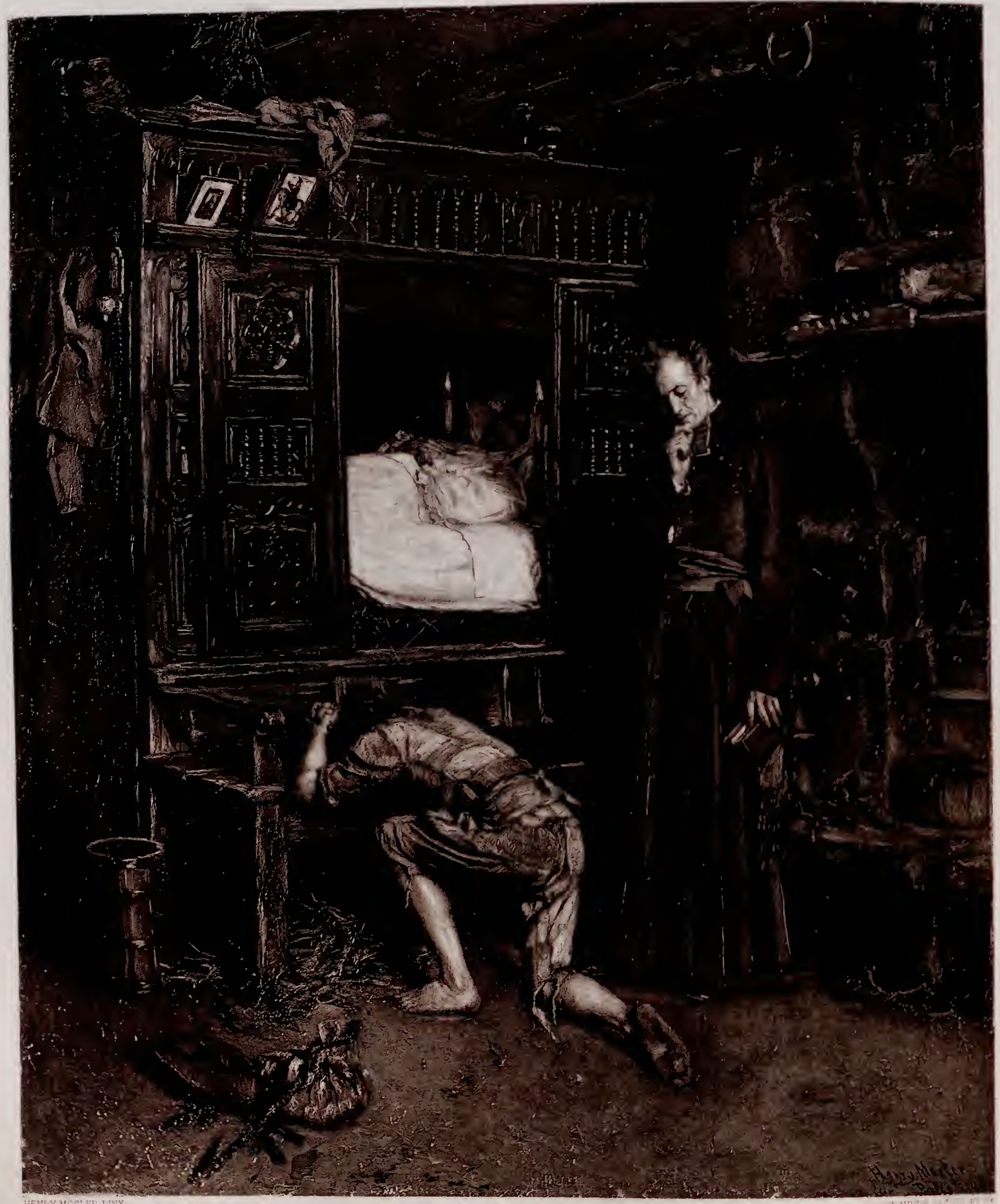




\section{The Return.}

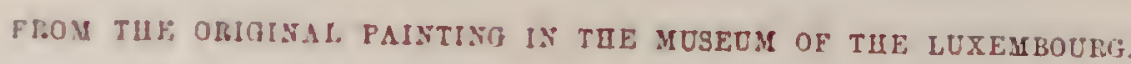

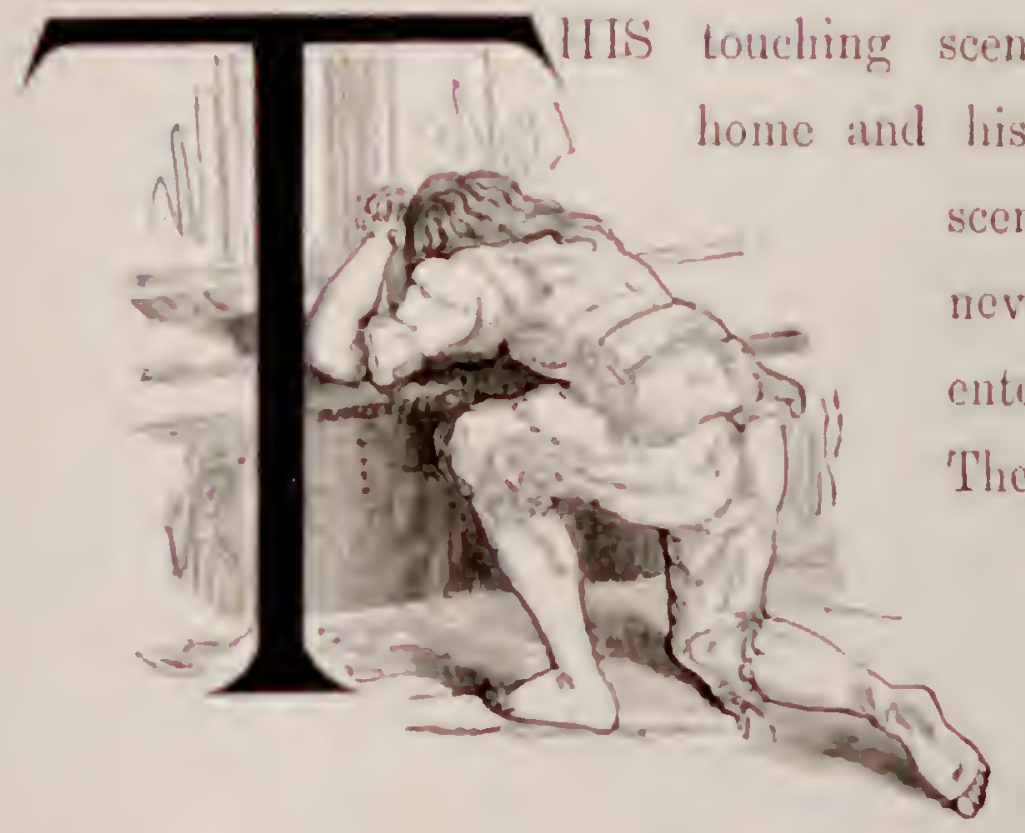
never failed him. But what anguish wrings his heart when, on entering the cottage home, he beholds that mother cold in death. The leart that so often ached for him, is at rest; the eyes that wept orer lis waywardness, and the hands that were lifted up in prayer for him, are peacefully composed. The mother's cares and sorrows are all past, and she lies now calm and peaceful in a sleep that shall be unbroken till the resurrection morn. It is now the protligal's turn to weep. Stricken with grief he falls to the earth, while the priect who soothed the mother's last hours, deeply commiserates the penitent and remorsuful son. The picture is strongly drawn and simply and most effectively composed, the interior being that of a cottage in Brittany.

The artist wats born in Now York, of Silesian parents, in 1841. His first employment was selling riggrs, and after that, he cngraved labels for cigar boxes. Removing to the West he learned wool engraving, and subsequently studied art with James H. Beard. During the late war. he was employed as a war artist until 1863, when he repaired to Düsseldorf where he studied two and a half years under Mueke and Kindler. After studying six months in Paris under Hébert, he returned to America, spent eight years in Cincimnati and New York, and then studied in Munich for three years under Piloty. In 1877 he went to Paris, where he has since resided. The Return, which was exhribited at the Salon of 1579 , enjoys the distinction of being the first work by an Americar artist ever purchased for the Museum of the Luxembourg. 



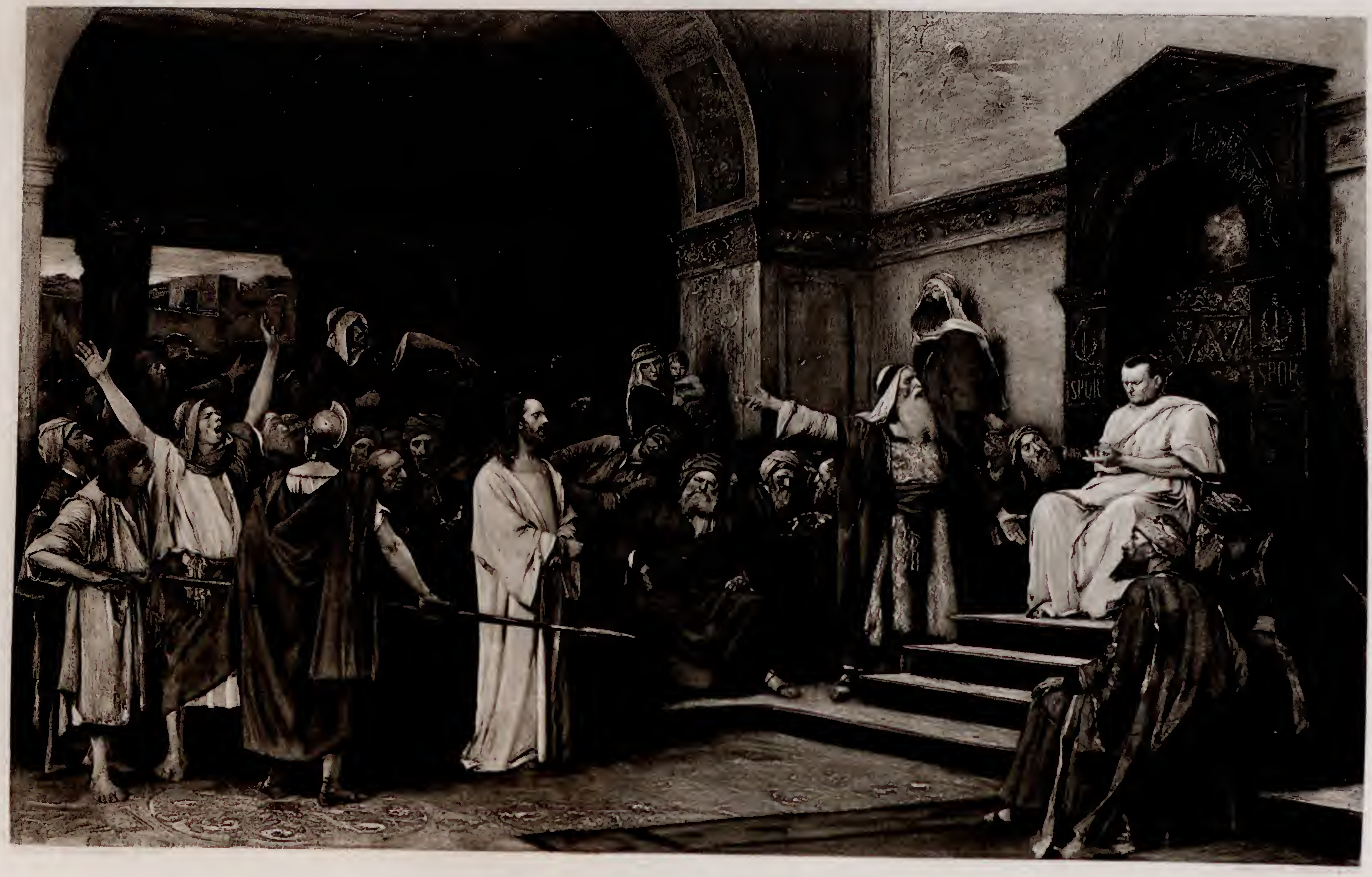




\title{
Christ Before Pilate.
}

\author{
PHOTOGRAVURE FROM THE ORIGINAL PAINTING BY M. MUNKACSY. \\ Owned by John Wanamaker, Philadelphia.
}

(HUNGARMAN SCHOOL.)

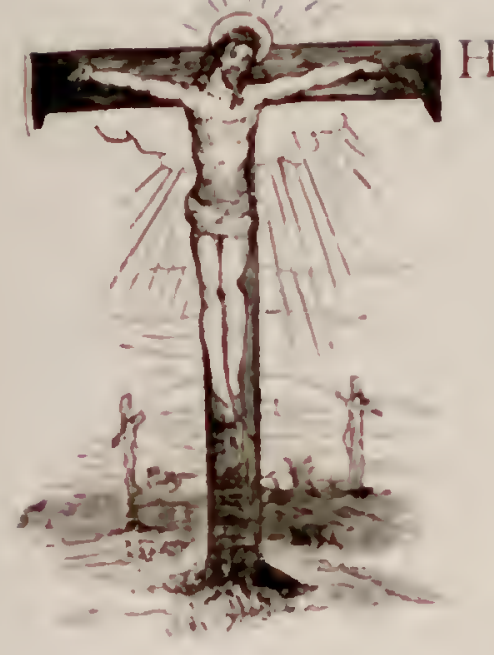

HE best description of this great painting we have seen appeared in the Boston Transcript, fron the pen of T. S. Robie. We abridge therefrom.

The sight of the Christ of Mu111kacsy is at first so startling, since the character attempted comes athwart all the conventional conceptions of the ages.

Let one contenplate the conception of Christ, as revealed with its impressive circninstances in this matchless painting of Mnnkacsy, in a receptive mood-the only attitnde which can interpret its mysteries to the soul and which is alike honorable to the genins of the artist-and he will not fail to feel as did one in another city, who said to a friend, with snppressed emotion, "It grows upon one like Niagara."

For a thonghtfinl observer of the face will find in it a justification for all the claims of Christ. While there is a neekness and submission portrayed, there is pre-eminently the manifestation of a majesty and decision which render it impossible to be the character of an imposter. One who studies that face, as scen in the painting, (or in this photogravnre), discovers a revelation there which justifies the exclamation of the donbting disciple, "My Lord and my God." In the majestic figure of Christ before Pilate, with that piercing look from which that cowardly governor wants to hide his face, one sees shmubering the Christ of Patmos, whose face shone as the sum, and before whose feet even the beloved disciple fell fainting. The downward look of Pilate, quailing in shame before the steady gaze of his prisoner, seens prophetic of that final hour when the Christ of the Judgment shall appear.

Christ Before Pilate was painted in ISSI-2 and exhibited in London, IS82. It has been exhibited in New York, Boston, St. Lonis and other cities. It is now owned by Mr. John Wanamaker, of Philadelphia, who is said to have paid $\$ 125,000$ for the work.

Milialy Mnnkacsy was born at Mnnkacs, Hungary, I846. After serving an apprenticeship to a carpenter he gained a bare subsistence by his trade, making at the same time strenuous efforts to gain an education. Of his works we may instance: The Night Prowlers; The Village Hero; The Government Pawn Shop; Christ Before Pilate; and Milton Dictating to his Daughters. The latter work was crowned with the Medal of Honor at the International Exposition, Paris, in I878. He received Salon Mcdals in 1870 and 1874 , and is Officer of the Legion of Honor.

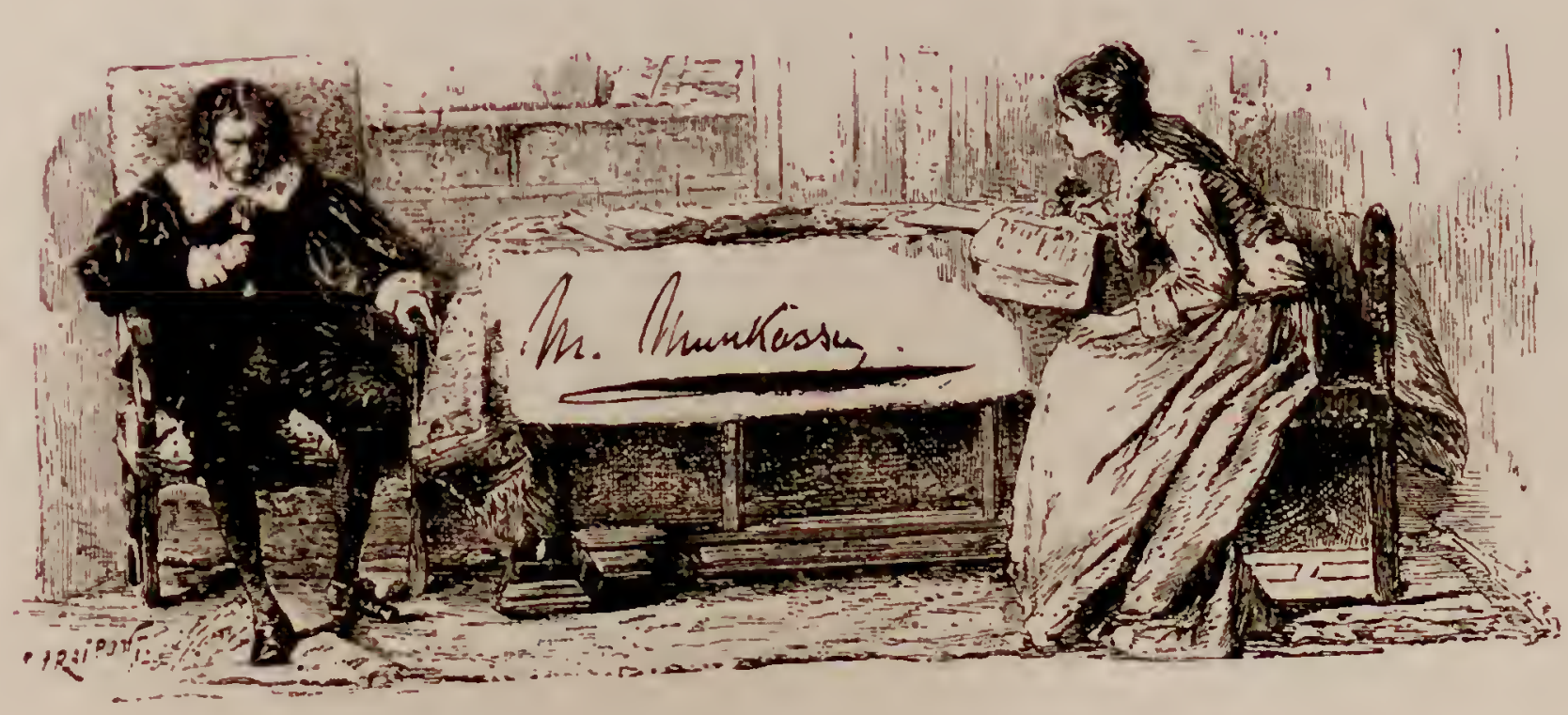





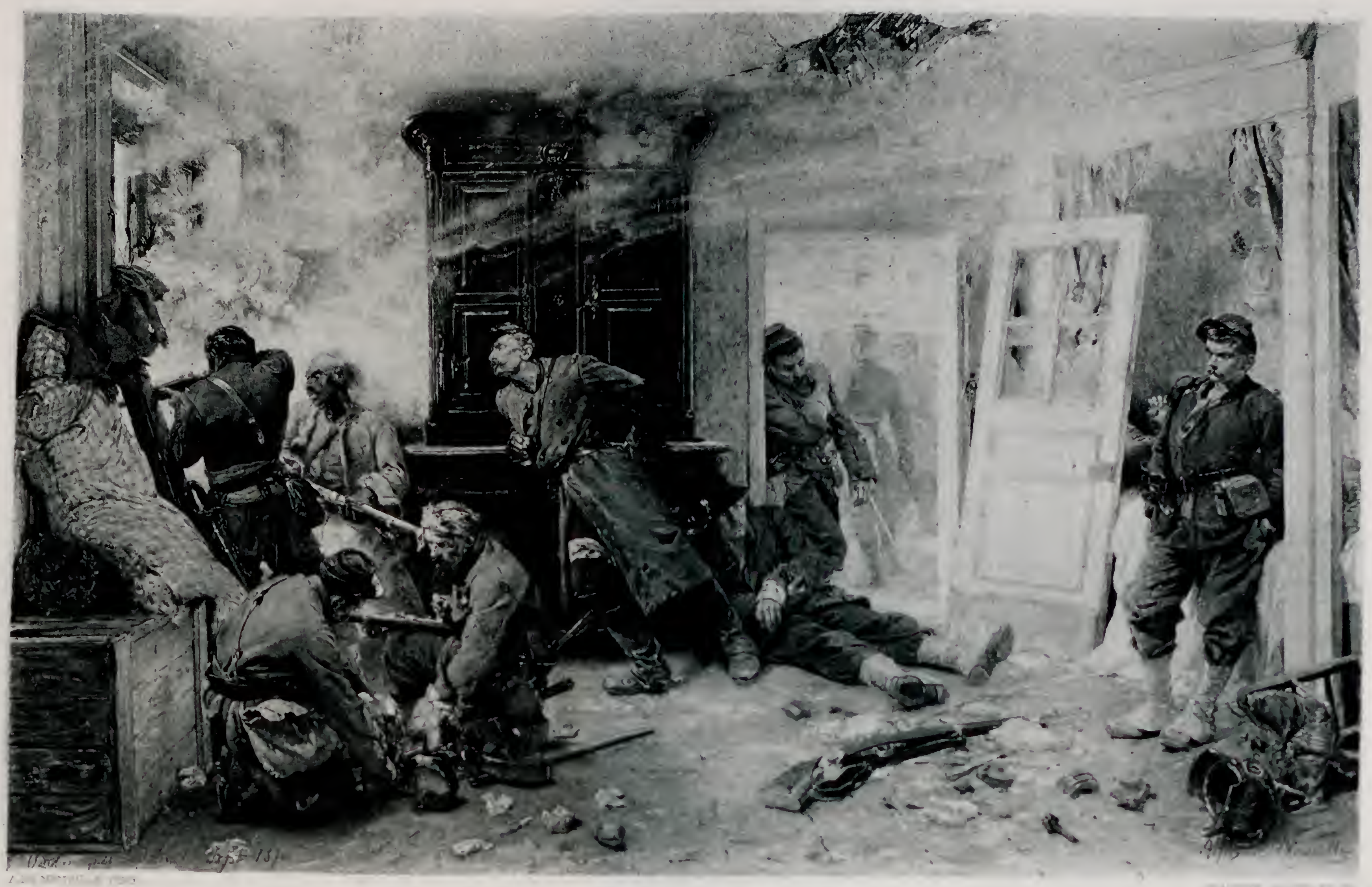




\section{THE LAST CARTRIDGE.}

EVER has a war been so faithfully illustrated as that of 1870-71. This graphically depicted incilent of a scene in the late Franco-Prussian war, has all the reality of the Irrin torrors of that sanguinary contest. De Neuville, himself a soldier, "smelt powder," and wils a participator in several battles. With an artist's eye, and with a cunning perfocted only in the present century, he has placed before us in the Last Cartouche, the very probable position of brave men reduced to the extremity indicated in the title of the picture.

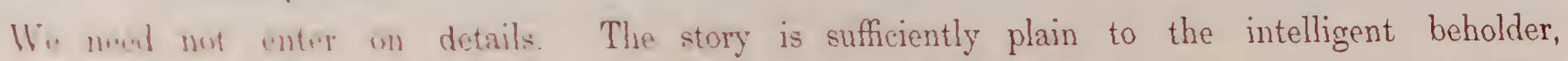
and no on. (aun help a pitying sigh that such bravery should be vanquished. If we contrast this picture with the hus of Battle Pietures crowding the Galleries of Versailles, or old Battle Pictures anywhere che-me will be satifficl that it is not alone in steam, and electricity, and general locomotion and communication that inen have improved.

Home. Vernet lenl the van of this now glorions school of military art. and it at present boasts of such illnetrion manes as Meissonier, Detaille, Pille, Dupray, and De Neuville. 




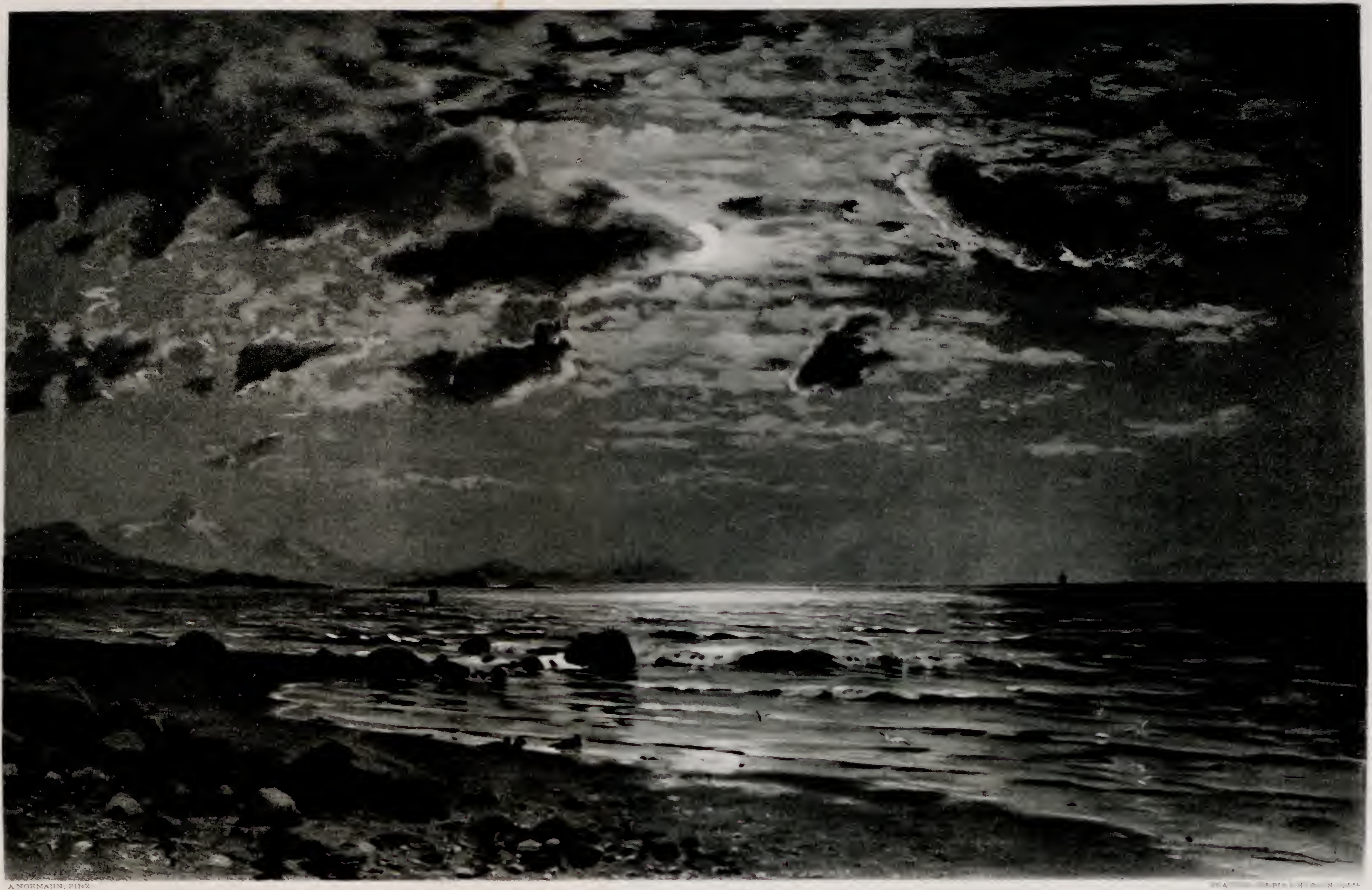




\section{Moonlight on the Sea at Lofoten, Norway.}

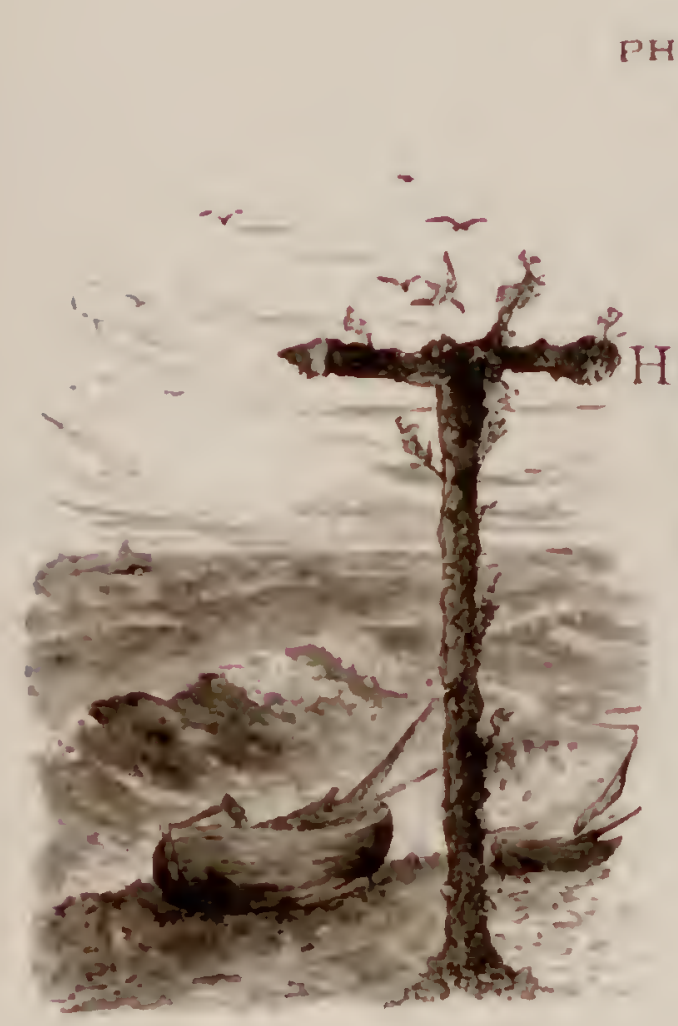

PHOTOGRAVURE FROM THE ORIGINAL PAINTING BY A. NORMANN.

(NORWLGIAN SCHOOL.)

E soft, poetic beauty of moonlight on the ocean is a sight equal to anything in nature for soft, pleasing satisfaction. All the great poets have paid their tribute to Moonlight. Milton sings-

\section{"Hesperus, that led}

The starry host, rode brightest, till the moon, Rising in cloudy majesty; at length Apparent queen unveiled her peerless light, And o'er the dark her silver mantle threw."

And the modern English poet, Charles Jeffries, opens a fine song with

\section{"Conne o"er the moonlit sea}

The waves are brightly glowing,"

which more perfectly describes M. Normamn's picture than any prose description we could give.

In the northern climes, where days are so long in the smmmer time that a very short twilight is all that separates day and night, the moonlight effect is particularly beautiful. The effect of the clondy sky and the simmering. glimmering sea in the painting is one of those touches of inspiration which marks the poet in the painter-the dream of a simbering ocean-filling the heart of the beholder with nost exquisite deliglit.

This painting, which was one of the most marked in the Salon of ISSS, and for which the painter received a nuedal of the second class, was sold to an English gentleman at a high price.

Adelstcen Normann was born at Bodö, Norway; studied art at the Academy of Stockholm, and finished his education at the School of Fine Arts in Paris. He is one of the most promising of the young artists of the Norwegian schonl.

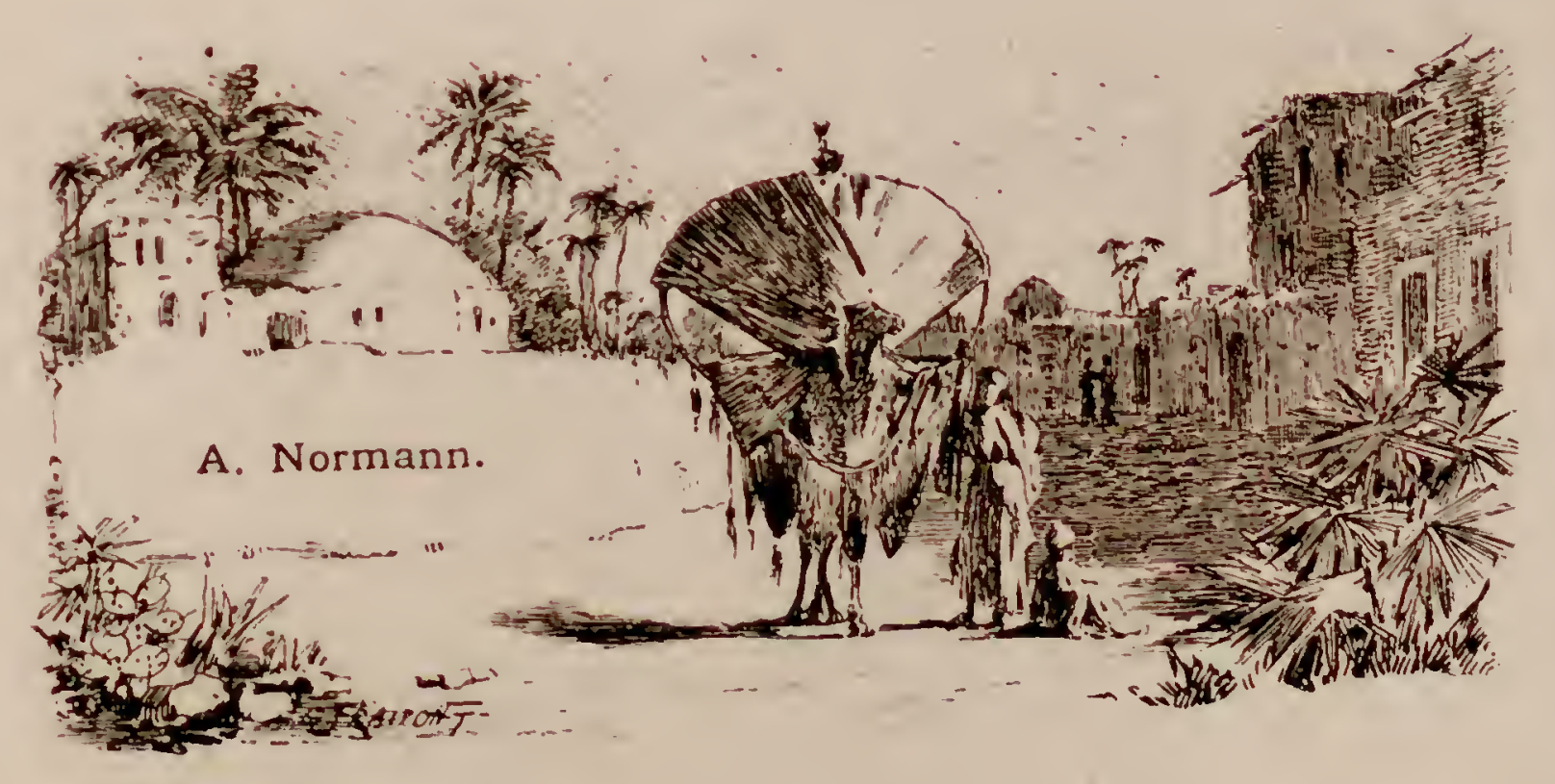






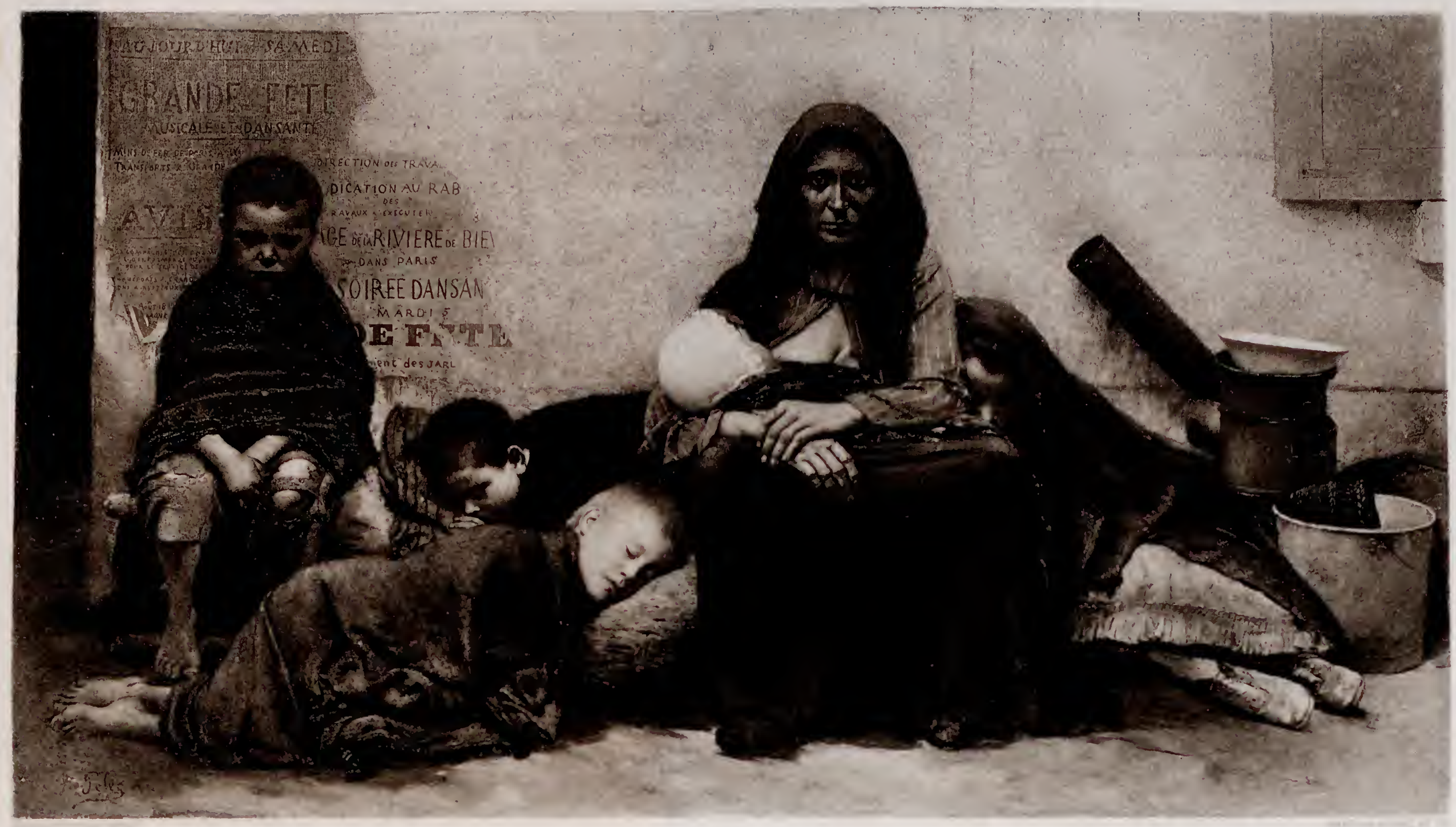




\section{Homeless.}

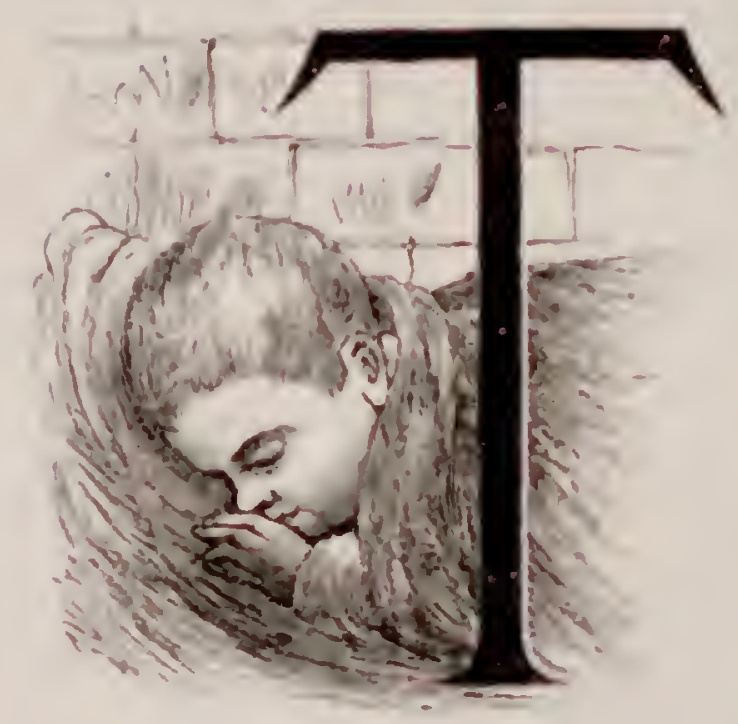

IIIS is one of the most remarkable examples of realistic painting extant. So true to nature is the group before us, that it might be a photograph of an mufurtunate fanily surprised in the extremity of their destitution: yet the scene bers cvidence of careful study in its composition. Again, the drawing and the expressions are so absoiute in their fidelity to truth that the spectator readily forgets that this is a painted picture, but rather heems himsclf in the presence of a real scene of woe. Unfeeling indeed mut be the heart that is not touched by such a scene: and yet how mnltiplical is this form of misery in all our cities!

Three of the chililen, secping in their rags, enjoy a short forgetfulness of their cold and hunger. The little follow whe sits on the left has a look of melancholy peculiarly toncling in one of such temule years. It sums as though a life-time of suffering had been compressed into his brief cxperiunce. The infint puafully drawing nourishment from nature's almost exhausted fountain, decpens the puthos of the ccom. ly throwing into stronger relief the surrounding misery. The poor mother's face wens thr louk of one who has exhausted her last resource, and who, for the moment, at least, abandons luevelf in at pitiloe fill. As we contemplate her hopeless expression we involuntarily pray that this dak hour may speealily u-lier in the dawn of a better day.
Alas! for the rarity
Of Christian charity
Under the sun!
O! it was pitiful!
Near a whole city full,
Home she had none.

How strongly this picture suggests the painful inequalities of human lots; and how eloquently it pleats for those who amidst plenty are starving, and who, surrounded by dwellings, mansions and palaces, are uncovered to every storm. It was one of the marked works at the Salon of 1883, and was by some of the critics judged worthy of the Prize of the Salon.

M. Pelez was a pupil of MM. Cabanel and Barrias. He received a medal of the third class in 1876, one of the scond class in 1879, and one of the first class in 1880. 




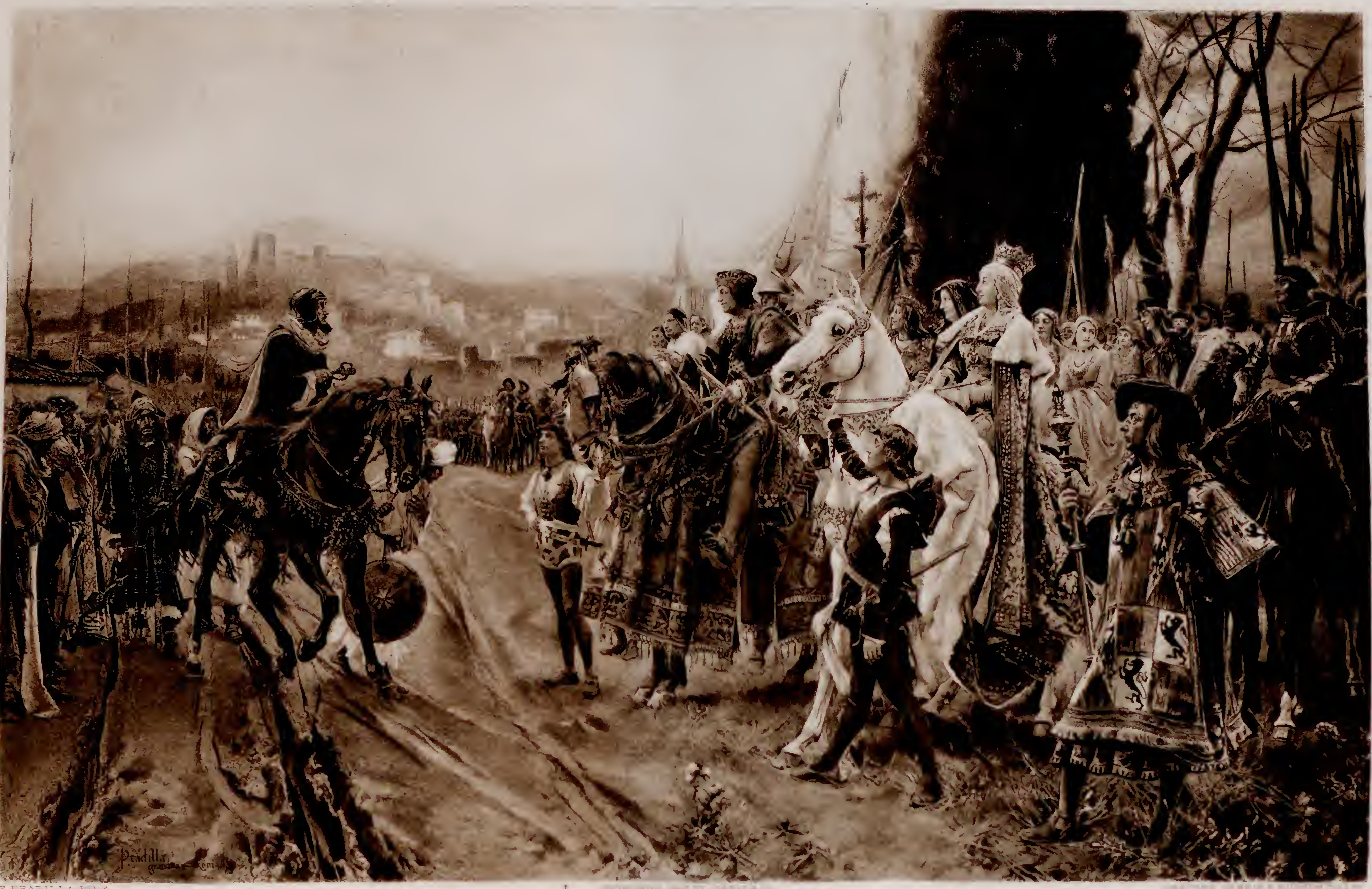




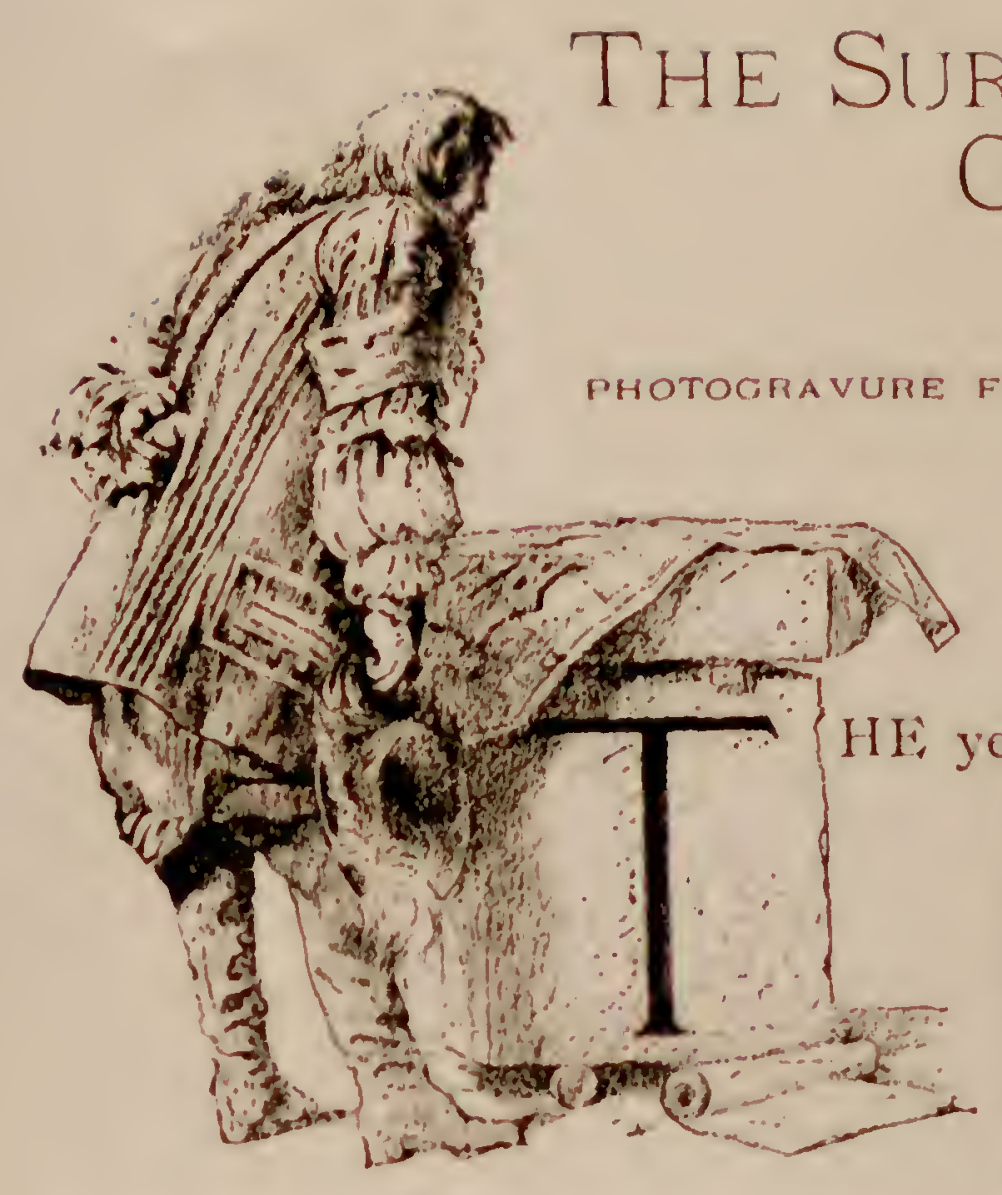

\title{
RRENDER OF THE, MOORS AT GRANADA, A. D. 1492.
}

\author{
THE ORIGINAL PAINTING, BY
SENATE CHAMBER, MADRID.
}

(SPANISH SCHOOL.) jer of Boabdil, the Moorish king, and his warriors to Ferdinand and Isabella. Granada had originally been founded by the Phonicians in the remote ages of antiquity, but was selected for the capital of the kingdon of Granada by the Moors in the eighth century, and rapidly became a wealthy city, the seat of trade, of arts, and architecture. Towards the end of the fifteenth century it reached its highest pitch of prosperity: In it was the palace of the Moorish kings, the Alhambra, surrounded by strong walls and many towers. The city was said to contain 400,000 inhabitants, and the city's walls were surmonnted with 1,030 towers.

Lord Bulwer Lytton, in his novel of Lelia, thus describes the surrender of the city, after a siege of twelve months, as follows: "Within sight of the royal group Boabdil halted, composed his aspect, but never in mien and majesty more a king, the son of Abdallah met his hanghty conqueror....

"Ferdinand and Isabella slowly advanced to meet their late rival-their new subject; and as Boabdil wonld have dismonnted, the Spanish king placed his hand upon his shoulder. 'Brother and friend,' said he, 'forget thy sorrows; and may our friendship hereafter console thee for reverses, against which thou hast contended as a hero and king.' Boabdil bowed his head, and remained a moment silent; then motioning to his train, four of his officers approached, and, kneeling beside Ferdinand, presented to him, upon a silver buckler, the keys of the city of Granada."

Sig. F. Pradilla is the most illnstrious painter of Spain of the present day. His works are not nnmerons, and none have reached the shores of America. At the World's Exhibition of 1878 at Paris, where all the painters of civilization competed, his picture of Dona Juana La Loca received the Medal of Honor of the Exthibition. The Surrender of the Moors was purchased for the Senate Chamber of Madrid for $\$ 40,000$.

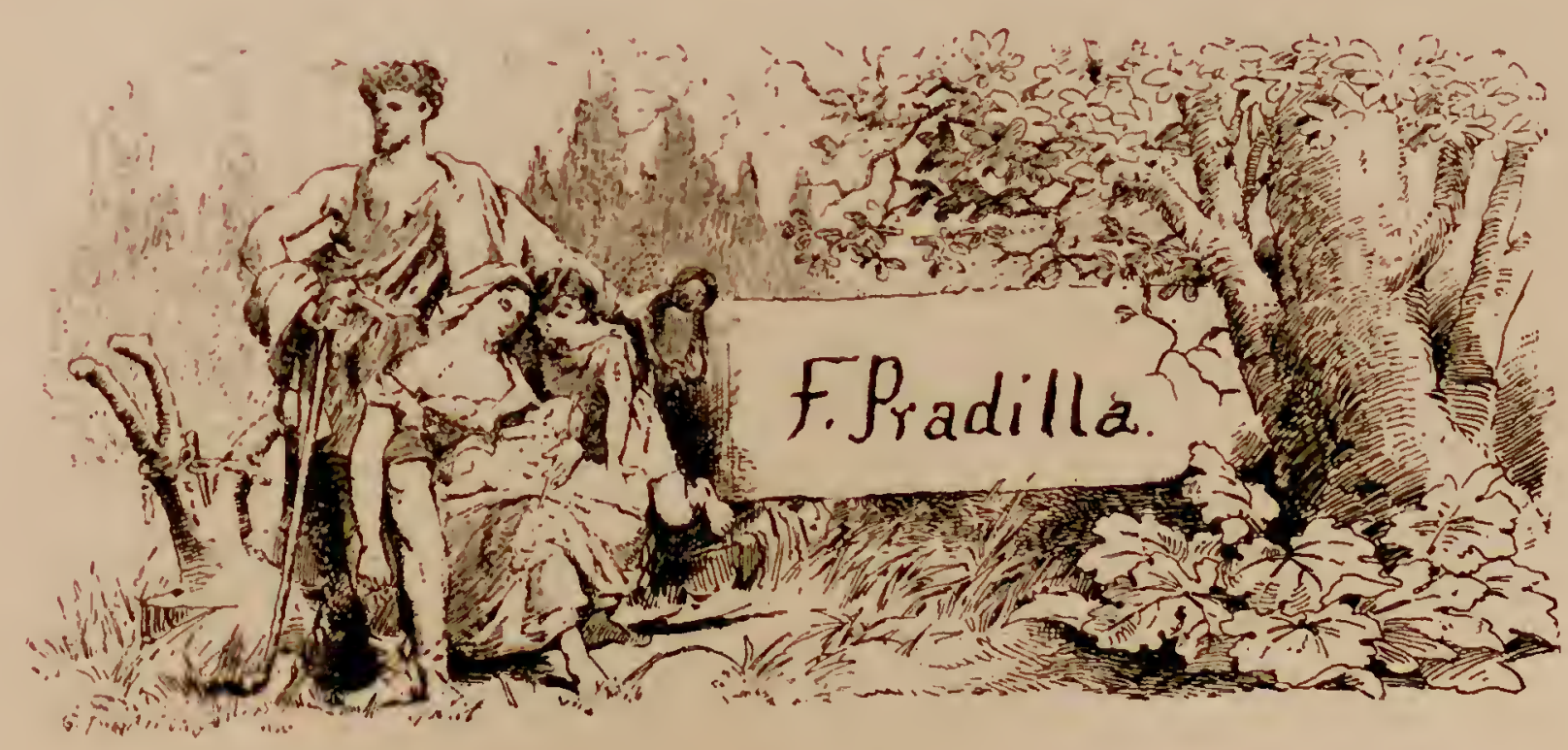






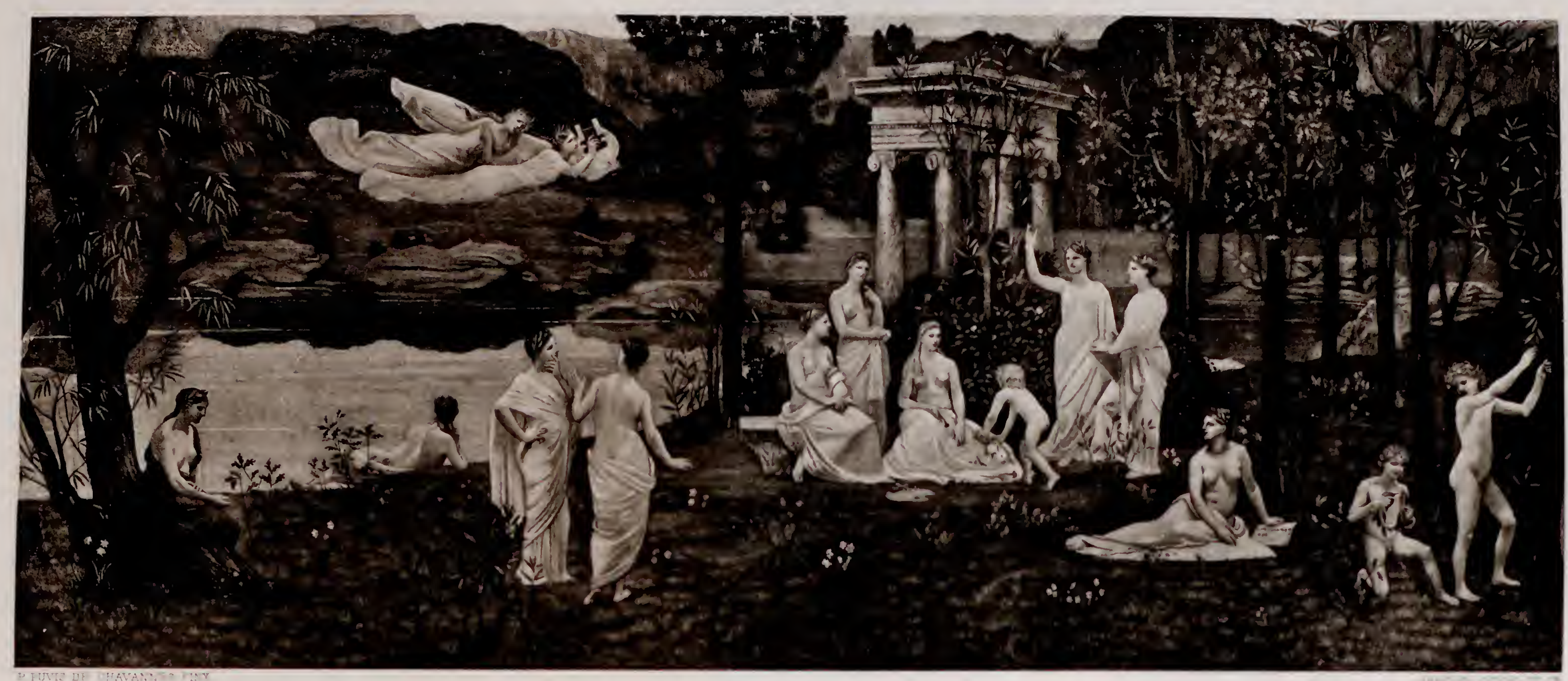




\section{THE SaCRED WOOD}

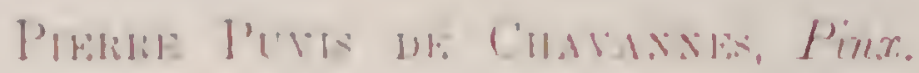

Goupre \& Co., Gramire

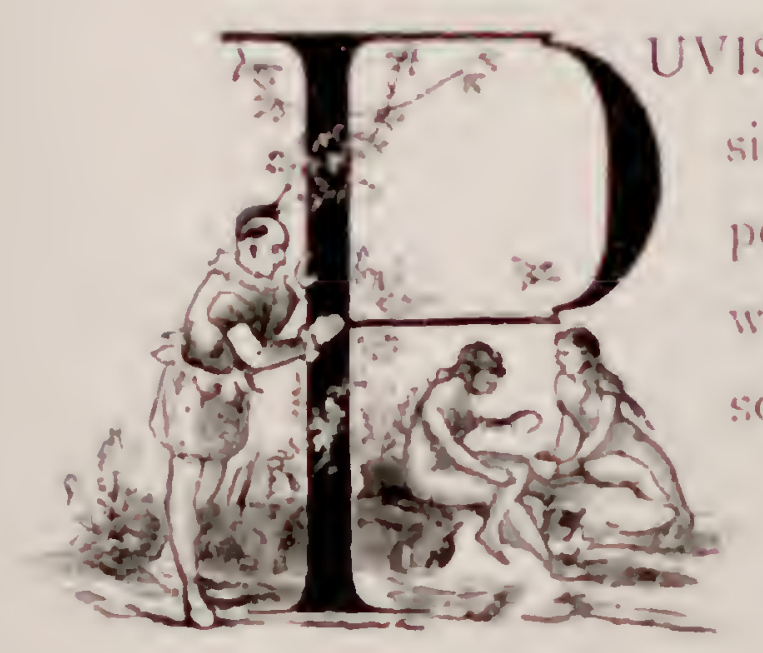

VIS DF: CHAVANNES holds a unique place among contemporary artists, not simply as a painter exclusively of idealistic works-mostly grand decorative com. positions-lut cspecially by reason of the calm and lofty spirit in which these works are conceived, ind for a style of design and a simplicity of feeling that is somctimes suggestive of certain early painters, whose fervent, childlike faith breathed in all their works. "The region that he paints," says Mr. Hamerton, "is not the world, but a painter's dreamiand, and the figures that dwell in it are not men and women, but the phantoms of a powerful, yet tranquil imagination. To enjoy works of this kind thoroughly; we must surrender ourselves to them, and live an hour in this worth of strange beings." "The Stered Wood, dear to the Arts and the Muses," is his latest and perhaps mose remarkable worl: The place, and the supernatural beings who inhabit it, are alike real to the artist: he believes in them, is profoundly in sympathy with them, and hence he paints them with a faith that is transparent and impressive. "In the centre is the fracment of an Ionic temple, flanked on one side by a large pool all soliten with the reflected rays of the setting sum. Two draped female figures float with an imperceptible motion through the still eveniner air. The landscape, which gladdens the eye with its contrasts of purple and pale grold, shows upright trees of moble shape, and gently swelling woods, with a background of mountains of mystic aspect, whose hues vary from a faint bue to a deep violet." The figures of the Arts and Muses are delincited with chaste simplicity alike in respect to form and the treatment of draperies. The picture was exhibited at the Salon of 1884 .

M. Puvis de Chavannes was born at Lyons in i824, and had for instructors in art successively: Ary Scheffer and Couture. He received Salon Medals in 1861 and 1864 : a third class medal at the Universal Exposition of 1867 ; and the Medal of Honor at the Salon of 1882 for his "Ludus pro Patria." He is Officer of the Lecsion of Honor. 




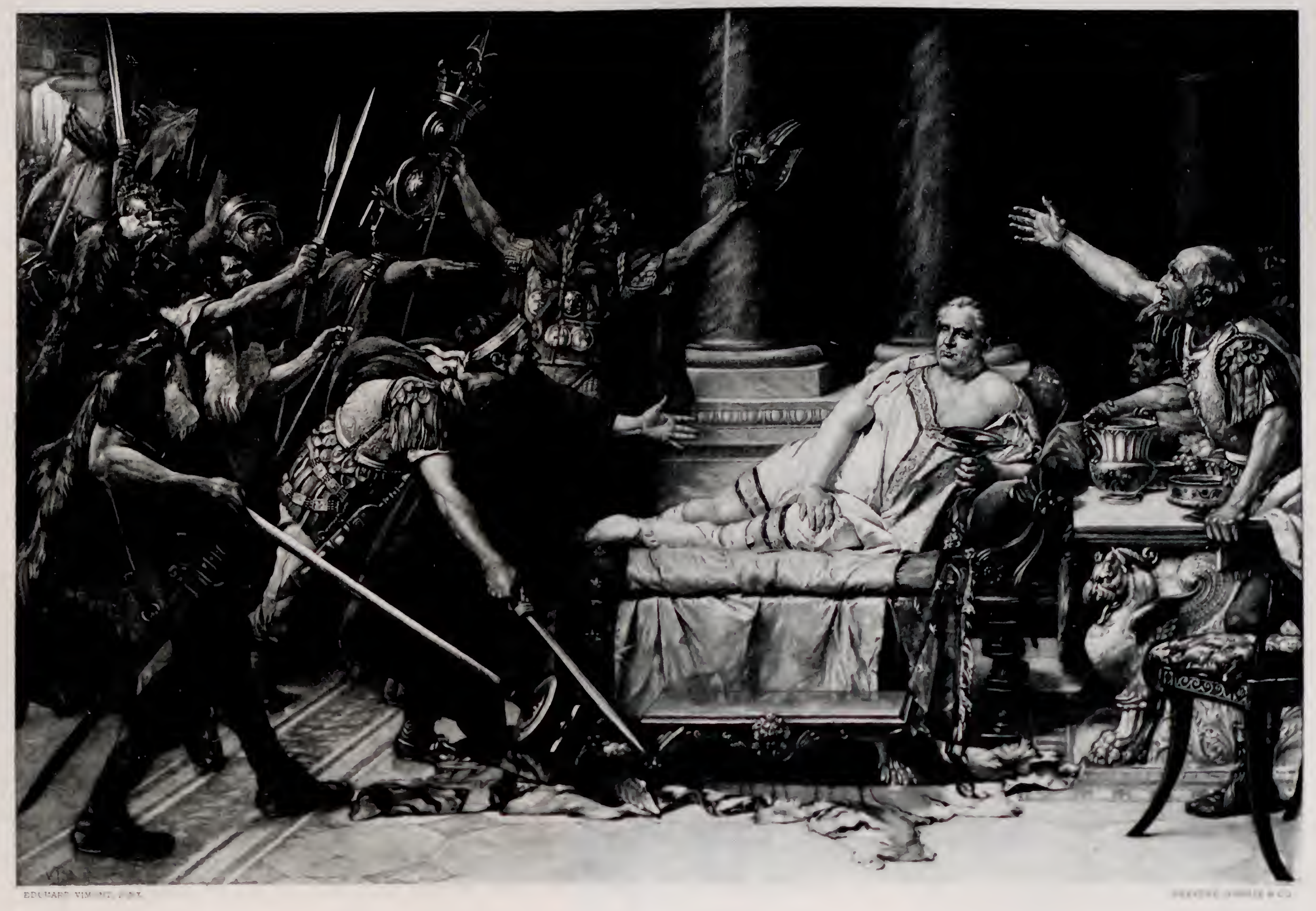




\section{The Death of Vitellius.}

PHOTOGRAVURE FHOM THE OHIGINAL PAINTING BY ÉDOUARD VIMONT.

(FRENCH SCHOOL.)

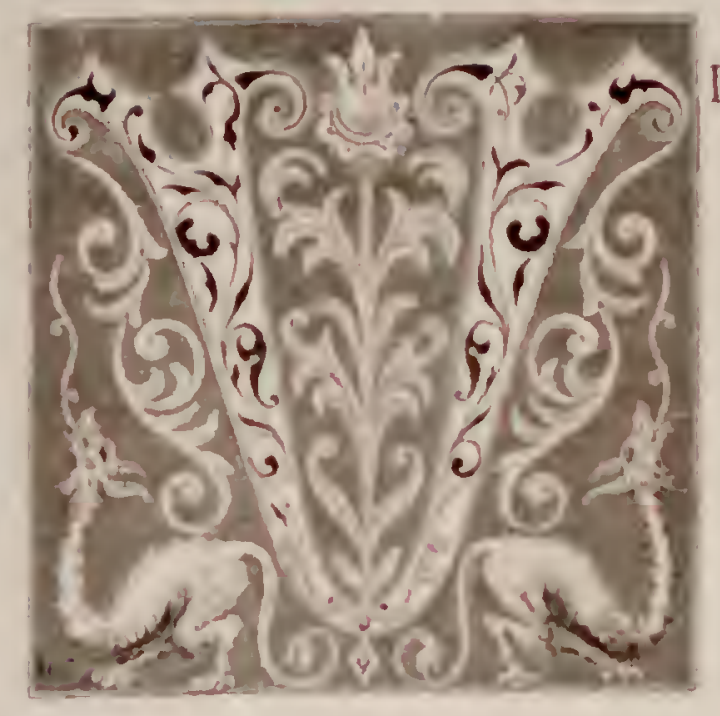

I'TELLIUS AULUS, Emperor of Rome, son of Lucilius Vitellins, prince of the sycophants who surrounded Caligula, was born September 24, A. D. I5, and through his father's inflnence became consul, A. D. 48, and afterwards proconsul of Africa, where his administration gave great satisfaction. He had been a companion of Tiberius at Capri and a favorite with Caligula, Claudins, Nero, and Galba, and was appointed by the latter commander of the legions in lower Germany, where he so gained the affection of his soldiers by extreme familiarity and liberality, that on Jannary 3, A. D. 69, they took him from his tent and proclaimed him Emperor. This election was adopted by the rest of the troops in Gaul, and two armies, mnder Valens and Cacina, immediately set out to secure Rome. Vitellins followed leisurely; and as the soldiers of Otho transferred their allegiance to Vitellius he was crowned with the imperial dignity. He was, however, so sunk in the vilest debauchery that the respectable part of the citizens of Rome rebelled and proclaimed Vespasian emperor. They were opposed by the Vitellian troops commanded by Cacina, but through the treachery of the latter general the troops of Vespasian were victorions.

For some time Rome was a scene of great violence and bloodshed, till the troops of Primus entered the city. Vitellius was found in his palace in a state of stupid terror, and after being ignominiously insulted was killed by repeated blows, A. D. 69.

The scene of the painting is illustrative of the last paragraph. After his death his head was carried abont the streets of Rome, and his body thrown into the Tiber.

M. Vimont was born at Paris, and is a pupil of M. Cabanel and also of Mr. Maillot. He has become distinguished by his powerful and correct drawing of the human figure, which he has on more than one occasion displayed to great advantage in historical paintings.

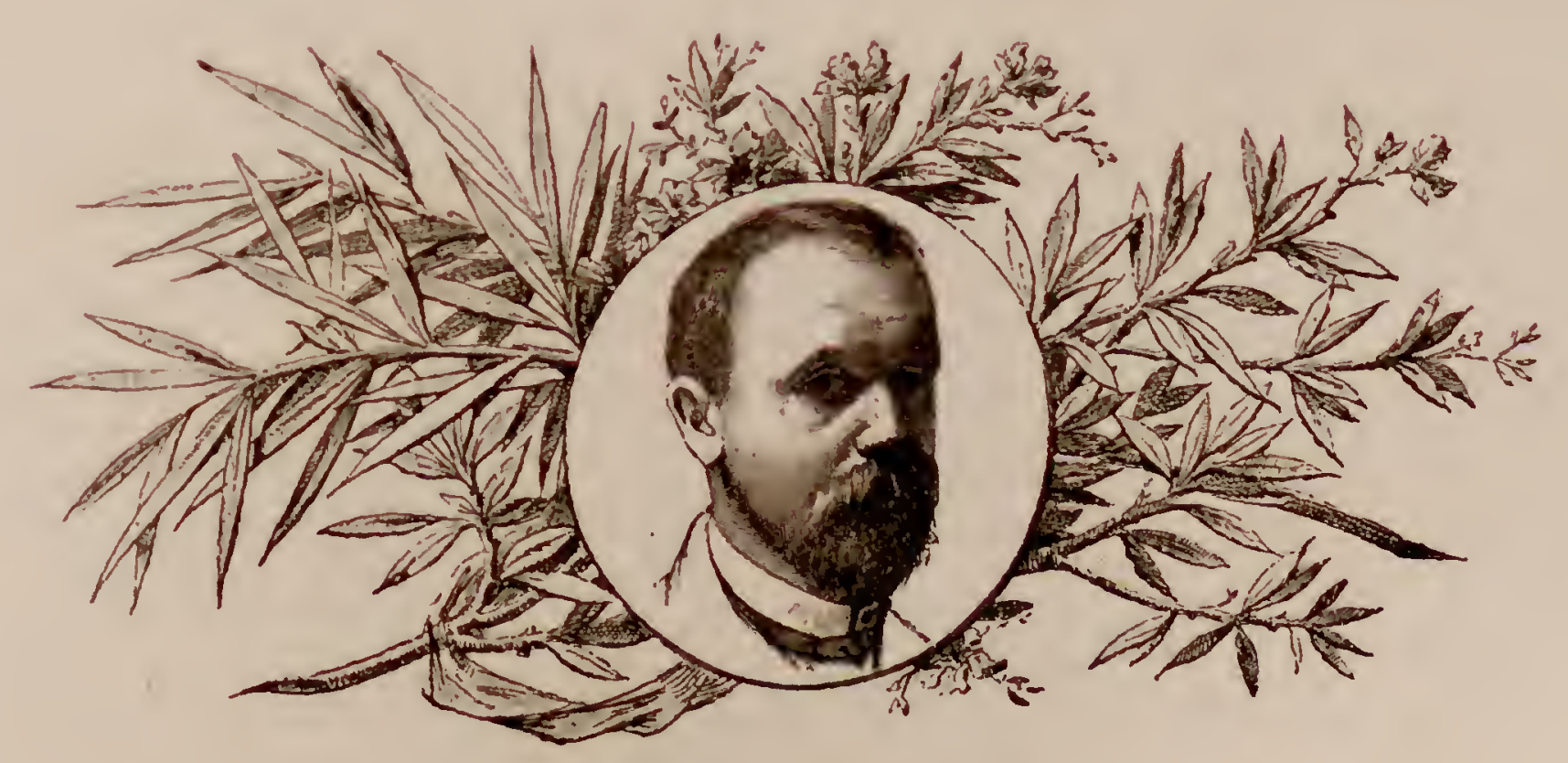






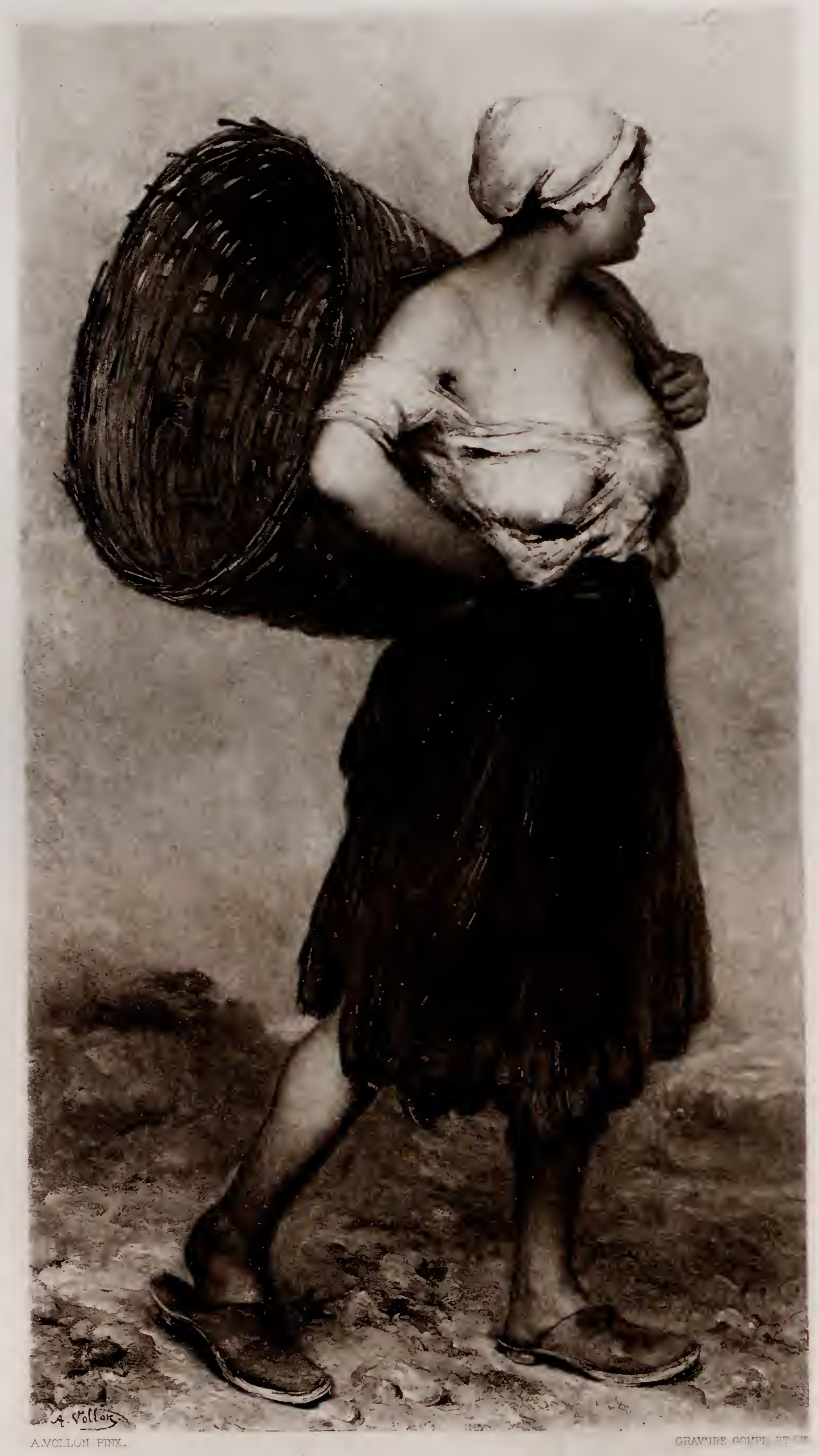

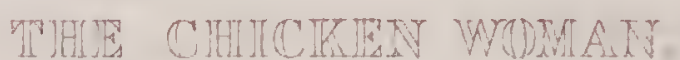




\section{The Chicken Woman.}

(HRON THE MUIGSAS PAINTISG IN THE GALLELY OF M, DUXCAN, PARIS.)

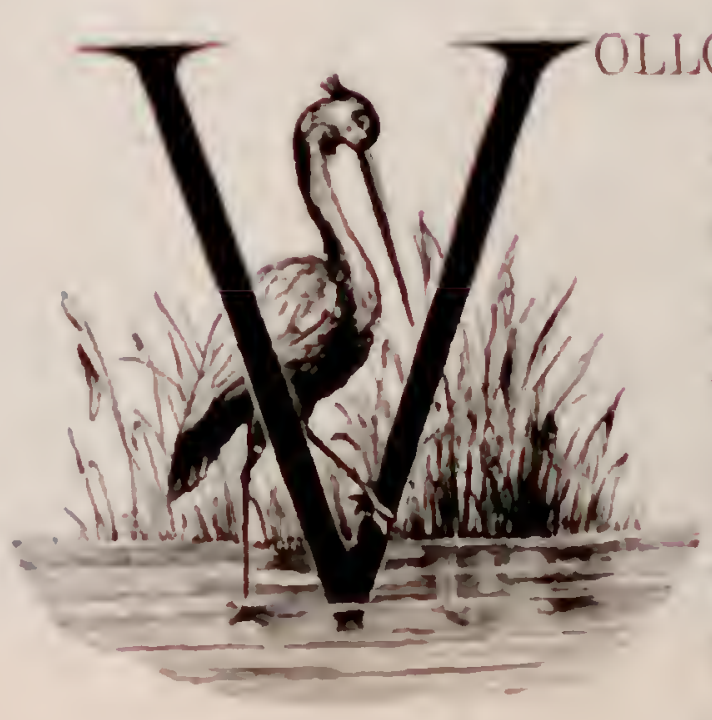

LION's Chicken Woman of Dieppe, was his Salon picture of 1876. Born at Iyons in 1838, he studied at the Academy of Lyons. He went to Paris and made his debut at the Salon of 1864 , achieving immediate distinction. Bdwin About, the great art critic, in writing of the Salon of 1864, says of Vollon: "Among the new names which the public has learned this year, I recommend to you especially, that of Vollon. His subjects are treated with decision, firmness and masterly freedom. The tones are just and true. This young man is truly strong." Since then he has been decorated more than once, and now is one of France's best artists.

The Chicken Itoman is simply an embodiment of vigor and freedom. With her hen "creel" (m) her shoulders, she steps forth a perfect Amazon. We are tempted to quote the criticism of an Ameriean gentlenmu, which we accidentally overheard at the Paris Exhibition of 1878 . He turned to his wife, on coming in front of Vollon's picture, and said, "Ain't she a buster?" Well, the remark is prertaps vulgar, but it is forcible, and a jage of criticisn could not better express the merits of the prainting. 




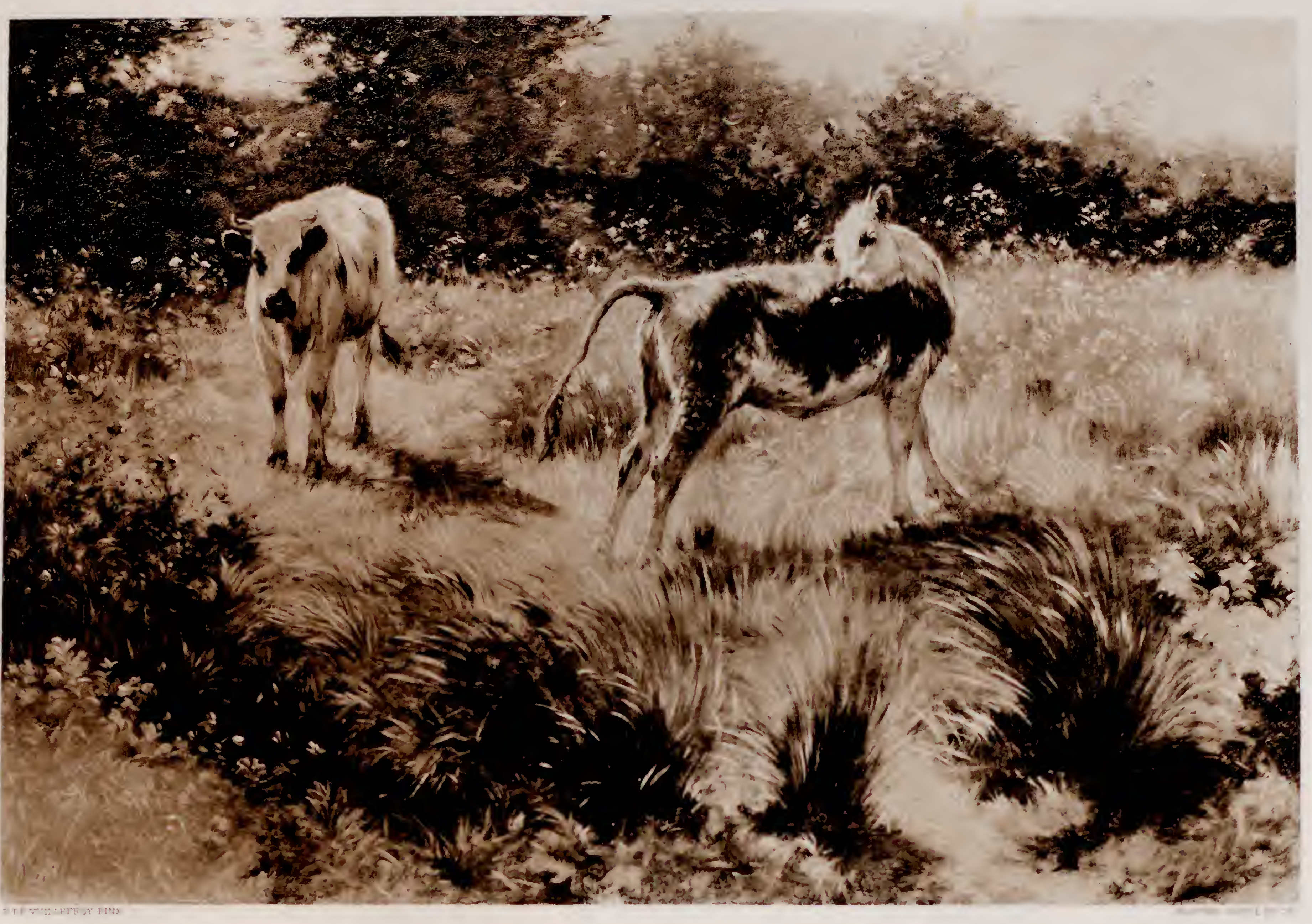




\section{A Summer Morning.}

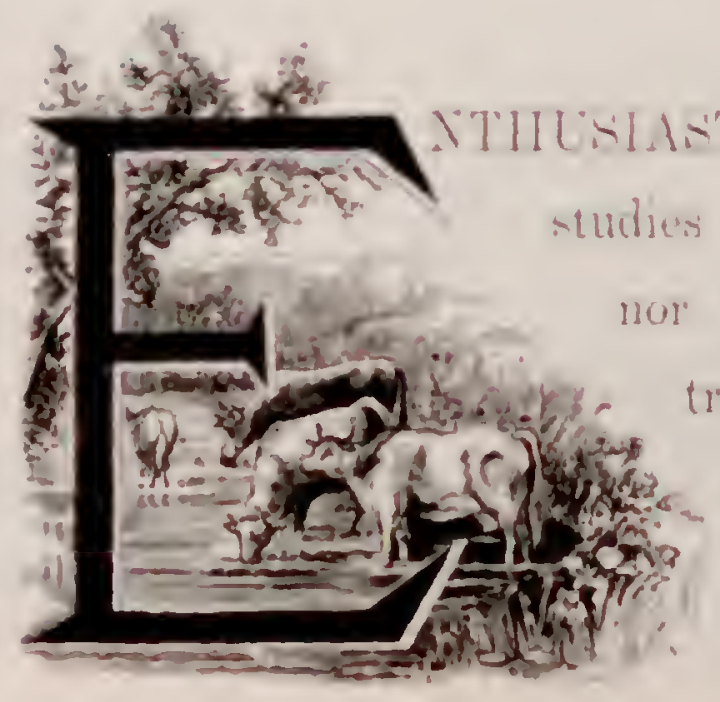

but esmon fincy that we inhalo the trenh outur of the fielus: certainly we must confess that cattle

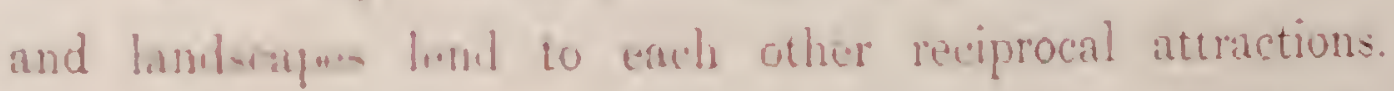

The number of painters whis hare excelled in this branch of art is small. The difficulties of stmly ar. preculinrly great. Thos who succeed must possess sufficient enthusiasm for their specialty to reconcile thrm tw much exposure and inconvenience. II. Tuillefroy, who is one of the foremost of livine mancre in this fieli, is a native of Paris, and studied under M.M. Hebert and Bonnat. His pictur tranopurts u: to the field where these pretty heifers are standing amid the tall, rank gras. It is a cus rorner, shut in by a living wall of green; and the play of light upon the scune is rery pleating. The picture was exhibited at the Salon of 1884. 




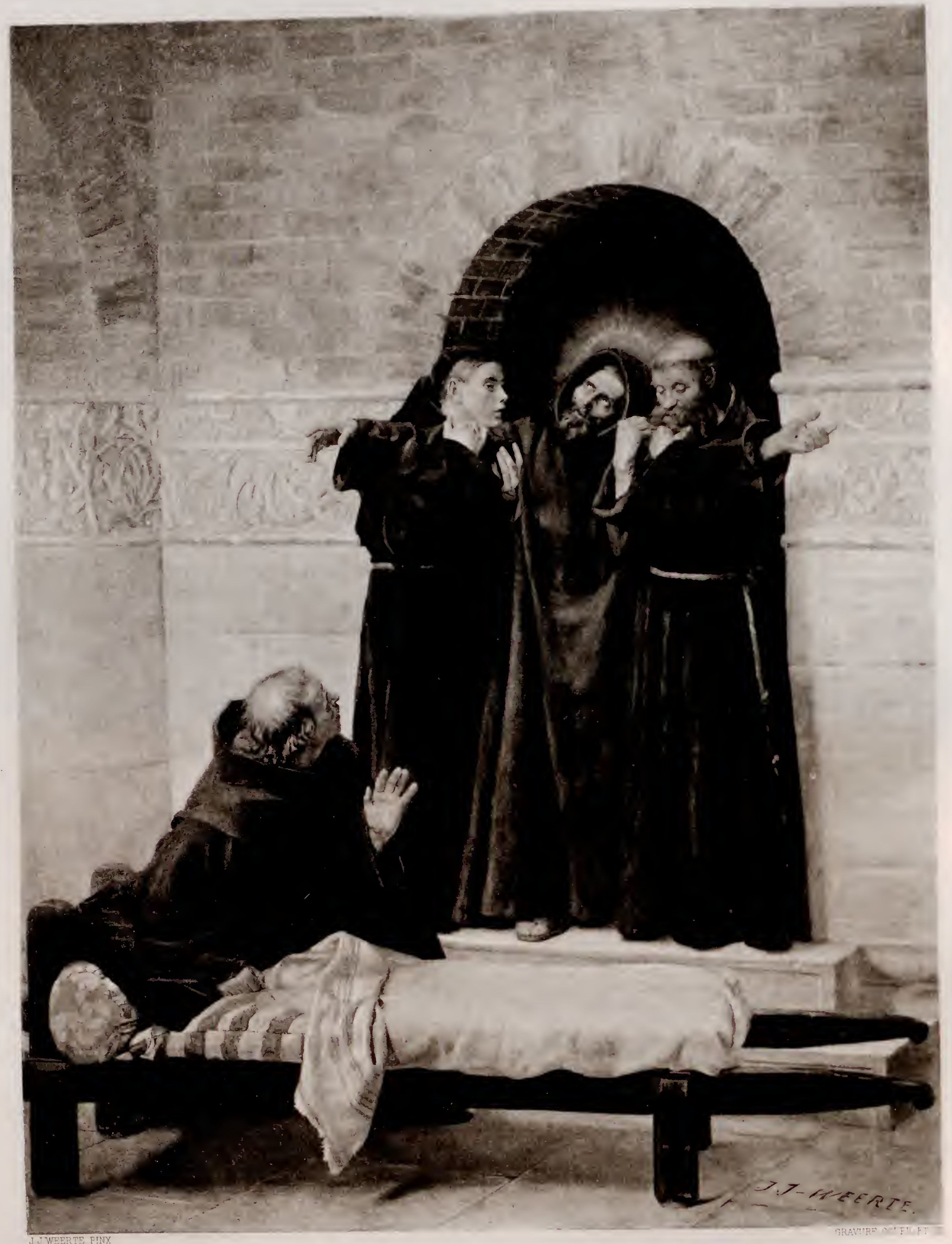

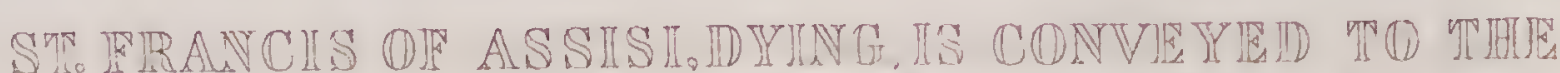

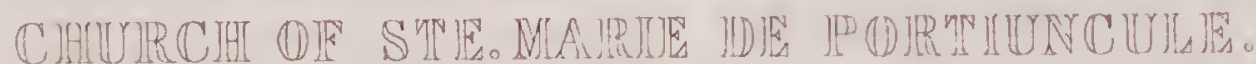




\section{St. FRANCIS, DYING IS CONVEYED TO THE CHURCH of Ste. Marie de Portiuncule.}

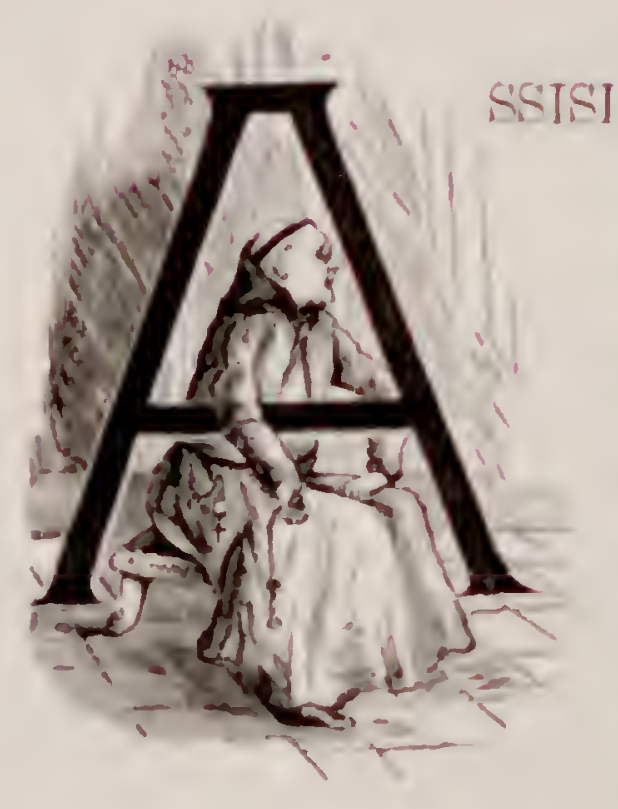

SSTSI, in Italy, owes no small share of its fame to the fact that it is the birthphace of the celelurated St. Francis, founder of the Mendicant Orders of Friars. 13e was the son of a rich merehant. A serious illness interrupted him in a career of fmodigality and tumed his thoughts to religion. On his recovery he hanl sureral visions, in one of which he was directed to repair the half-ruined mumeh in which he was then praying. To do this he sold a piece of property, which so incensect his father that to escape his wrath he hid himself in a wave. When the retumed he was so haggard and ragged as to be scarce reengnizable. His father at first deemed him insane; but afterwards took him to the bishop for commer. Francis cast himself at the bishop's feet, abjured his former life, and throwing off his fine chuthing sail, "Henceforth I recognize no father but Him who is in

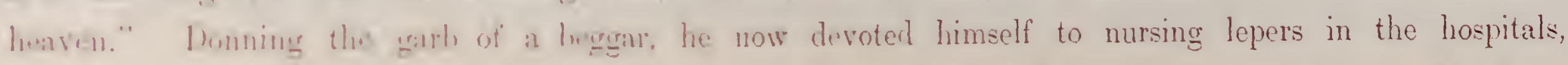
to wambring ahout collecting alm- for the repair of churches, and other religious works. He lived in a coll, and unal only the barest necessiries of life; he esen threw away his leathern girdle, taking intend a rope of hemp, which example, being copied by his followers, procured for them the mane Curdelins. The funn of his pricty soon attracted disciples, and at length he went to Rome, where, after heing at first repuled, he obtained from Pope Innocent III. the privilege of founding an Order. Ten years later 5,000 firurs attented the first general chapter of the Franciscans. He is reputed to have worked many miracles. Poverty, limmility and charity were his cardinal principles. Several years before his death he retired from the head of his order and dwelt in a cave on Mt. Alverna. Here he hand many risions and ecstasies, chief of which was that in which he received the stigmata (the nail frints in his hands and feet and the mark of the spear in his side). As deatlo drew near, he was, at his request, borne to the Church of Ste. Narie Portiuncule.

The painter has chosen this incident for illustration. The mingled pain and rapture on the face of the dying Francis and the reverential tenderness, touched with awe, shown by his attendants, signalize the work as one of marked power. M. Weerte is a native of Roubaix, France, and was a pupil of M. Cabanel. 




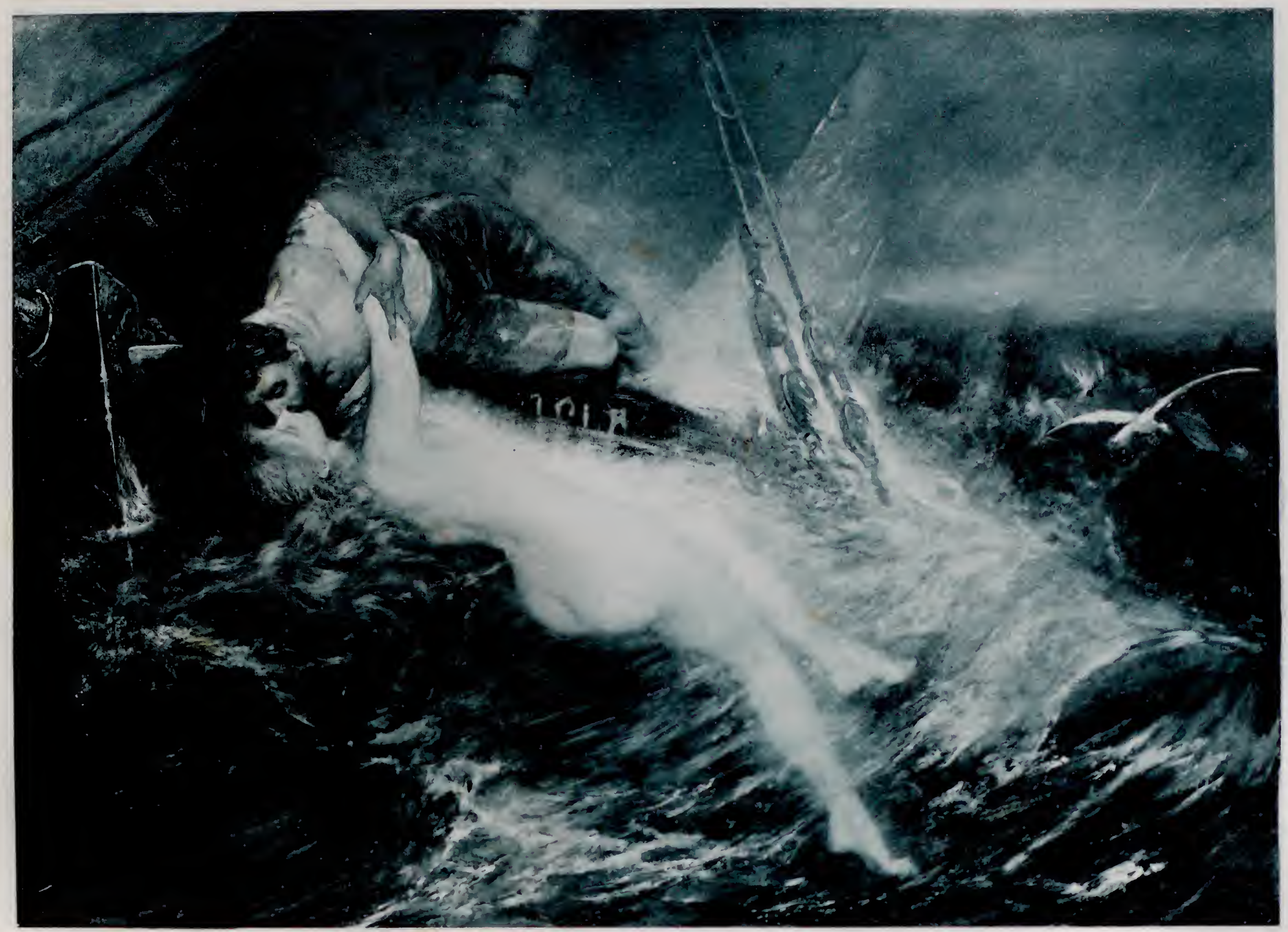




\section{THE Kiss of THE SiREN.}

FROM THE ORIGINAL PAINTING BY GUSTAVE WERTHEIMER

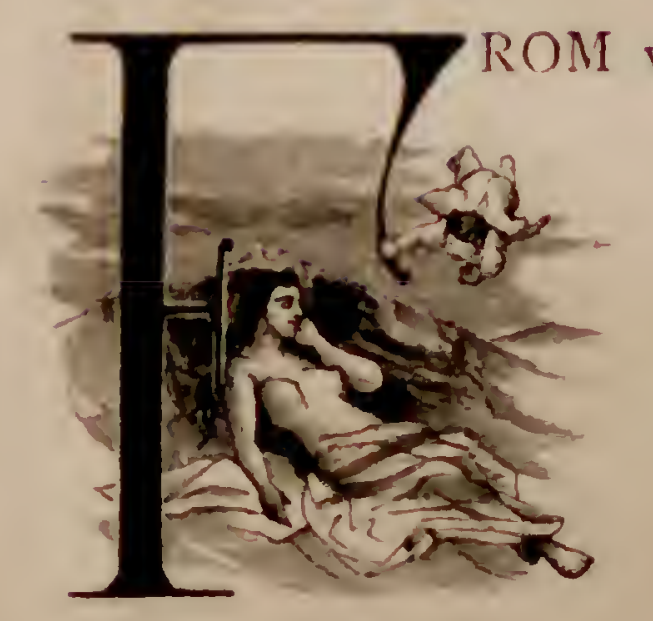

very ancient, down to mediæval, times the popular imagination has been stirred by accounts of sea nymphs of wondrous beauty and ravishing powers of song, who by their wild, resistless melodies, lured mariners to shipwreck and death. The most noted of these deadly charmers were the Sirens. All are familiar with the story of Ulysses who, as he approached their home, filled the ears of his sailors with wax, that they might, through deafness, be insensible to the Sirens' songs, and then caused himself to be bound to the mast, so that, while hearing their maddening melody, he would yet be powerless to yield to its fatal spell. When ihe Argonauts were obliged to pass that perilous spot, they took with them for safety Orpheus, that the music of the Sirens might be counteracted by melody even more magical than their own.

The most famous of these fatal enchantresses of more modern times was the Lorelei, the beautiful nymph who, perched on a high rock upon the Rhine, would sing such ravishing songs as made the doomed mariner forget his boat till it was broken on the sunken rocks, and he himself was cast dying upon the shore. Such, perhaps, has been the occupation of the Siren in our picture, who now completes her fatal work. The charmed sailor, forsaking his last chance of life, turns passionately towards the pale sorceress, and clasps her in a lingering, expiring embrace. Concerning the intensity of truth with which the artist has expressed the melancholy catastrophe, and his faithful representation of the wild waves and sky, we need not speak. Gustave Wertheimer is a native of Vienna. He is an artist of rising fame, and excels especially in the treatment of the romantico-tragical subjects of mythology and history. 




